
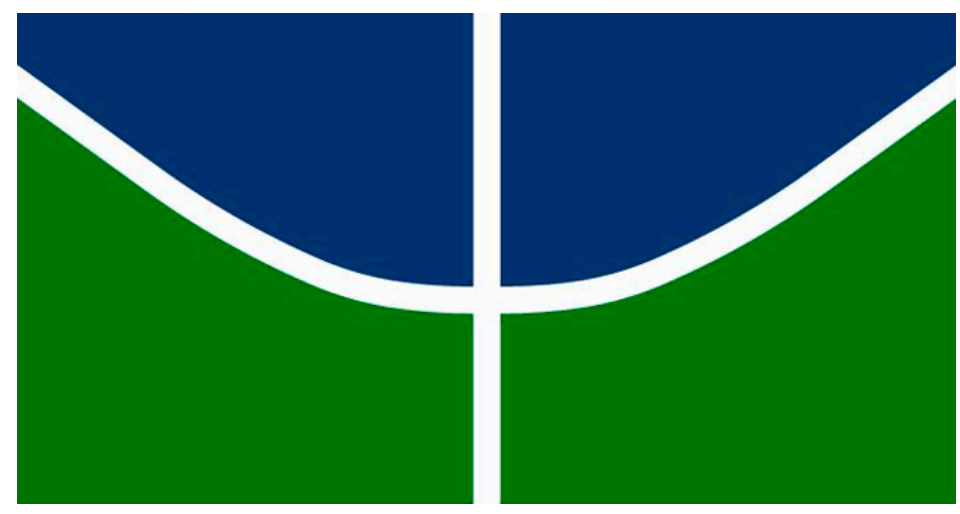

Universidade de Brasília - UnB

Faculdade de Comunicação - FAC

Programa de Pós-Graduação em Comunicação

Linha Imagem, Som e Escrita

\title{
PEGADAS DE DINOSSAURO
}

Uma expedição teopoética pelo cinema de Terrence Malick

\section{Guilherme Lobão de Queiroz}

Matrícula: 14/0075160

Orientador: Prof. Dr. Sérgio Araujo de Sá

Brasília, 2015 

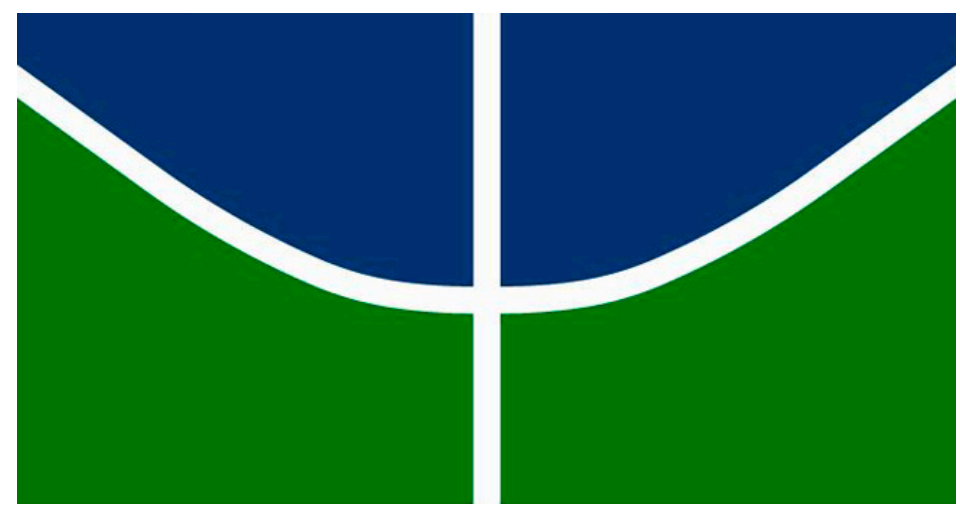

Universidade de Brasília - UnB

Faculdade de Comunicação - FAC

Programa de Pós-Graduação em Comunicação

Linha Imagem, Som e Escrita

\section{PEGADAS DE DINOSSAURO}

Uma expedição teopoética pelo cinema de Terrence Malick

Banca de Defesa de Dissertação

Prof. Dr. Sérgio Araujo de Sá (presidente)

Prof. Dr. Gustavo de Castro (membro)

Prof. Dra. Claudia Busato (membro)

Prof. Dra. Susana Dobal (suplente)

Brasília, 2015 


\section{Resumo}

Pegadas de dinossauro: uma expedição teopoética pelo cinema de Terrence Malick propõe investigar consonâncias e dissonâncias da realização cinematográfica do diretor norte-americano em relação a aspectos de uma poética que persegue o divino. Mediada pela poesia, a dissertação busca empreender uma jornada em busca de vestígios estéticos que conferem à obra de Malick um caráter estilístico singular. Por meio de análises dos planos, das paisagens, do uso da luz natural ao limite, da trilha sonora, da voz over, da moral religiosa, do afeto, das trevas, da vida, da natureza e da graça presentes em cada um dos seis filmes do diretor (considerando apenas os que estrearam em circuito comercial até julho de 2015), desenharemos uma cartografia teopoética à luz do conceito do teólogo alemão Karl-Josef Kuschel, porém assumindo como espinha dorsal diálogos com a fenomenologia dos devaneios de Gaston Bachelard, de onde pretendemos desvendar o instante teopoético em Malick.

Palavras-chave: cinema, poesia, teopoética, Terrence Malick, transcendente 


\begin{abstract}
Dinosaur trails: a theopoetic expedition throughout Terrence Malick films concerns the consonances and disonances of the american director's work in relation to aspects of the poethics of the divine. Mediated by poetry, the present dissertation engages a journey in order to find aesthetics traces which give Malick's cinematography an unique stylistic feature. Throughout analisys of framing, landscapes, natural light at the limit, soundtrack, voice over, religious moral, affection, darkness, life, nature and grace in each one of his six full-lenght movies (considering only the theatrical releases dated 'til July of 2015), we will delineate a theopoetic cartography illuminated by the concept of german theologist Karl-Josef Kuschel, taking on, as backbone, a close dilaogue with Gaston Bachelards's reverie phenomelogy.
\end{abstract}

Keywords: film, poetry, theopoetics, Terrence Malick, transcendent 


\section{Agradecimentos}

Uma poesia adequada para retribuir agradecimentos aos anjos que colaboraram com este trabalho não cabe em palavras. Portanto limito-me a relacionar alguns:

A Adriana, mulher de fé, companheira de todos os momentos, amor da minha vida A Teodoro, meu filho, que acalenta meu coração na noite quieta e no dia sorridente A Newton Scheufler, o primeiro a incentivar minha incursão acadêmica

A Mauro Giuntini, que apoia meus devaneios desde o início da jornada científica A Gustavo de Castro, que defendeu minha incompletude e inspirou-me ser (transcender)

A Pedro Russi, por ensinar-me a abduzir (embora ainda não tenha aprendido)

A Tiago Quiroga, provocador do exercício de pensar

A Sérgio de Sá, meu guia metafísico

A Claudia Busato e Susana Dobal, generosas instrutoras

A Joe Santos, por apresentar-me Kuschel e me orientar sem mesmo me conhecer

A Taís Rocha, sempre de prontidão a me socorrer no meu francês limitado

A Esdras e Danícia, meus queridos pais que até hoje me dão colo

A Nalci e Rose, meus queridos sogros que são como pais

A Gabriel e Pri (e Gael); Érico e Cláudia; e Cintia, meus irmãos, por serem irmãos

A Dindinha e Vó Hilda, por tudo

A Ana Flávia, Alan Marques, Ronald Souza, Renato Pinto, Vinicius Barreto, Aida Feitosa, Alan Oliveira, Rafael Lobo, Anna Lisbôa, Bernardo Scartezini, Felipe Moraes e demais colegas, parceiros, confidentes e mentores que me inspiraram com papos edificantes acerca de prosa e poesia ao longo desse período

A Deus 
Aos de casa de onde sempre saio para onde sempre volto 


\section{Sumário}

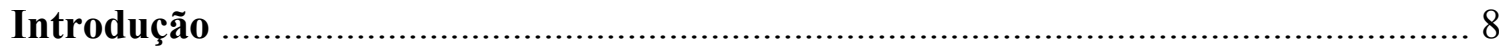

Capítulo 1: No horizonte, a estrela d'alva - evidências de uma teopoética.....................20

- sopro do espírito: a voz da devoção

- dilemas da gravidade e o sonho de voo

Capítulo 2: Sonhos diurnos a caminho de Emaús...................................................... 38

- orvalho espiritual e dilúvio interior

- o dogma da extinção (paraíso perdido)

Capítulo 3: Coreografia da adoração: o gesto teopoético

- liturgia da alma: o ferreiro, o oleiro e a sina laboriosa

- devaneios sobre o ato de cavar poços no deserto

Capítulo 4: Soli Deo gloria: o rito da paisagem

- traços do invisível

- o mito revelado

Considerações finais. 98

Referências bibliográficas .104

Referências filmográficas

Anexo

Frames cinematográficos que serviram como ponto de partida de análise e fundamentaram muitos dos devaneios. Um exercício do instante. 


\section{Introdução}

Pelo cinema, a arte se faz luz. Pela luz, o cinema se faz arte. O luzir apresenta-se de três formas: artificial-mecânica, mediada pelo dispositivo (o obturador da câmera fotográfica); natural-orgânica ("haja luz"1) e transcendental-poética (residência da imaginação, da metafísica, da verticalidade ${ }^{2}$ ). Por essa última possibilidade flanam os objetivos desta dissertação. Os outros dois, contudo, não serão ignorados; estão conscientemente interligados entre si. Empreenderemos a partir daqui uma expedição com finalidades sensíveis, embora talvez invisíveis, como o estrondo de um passo de dinossauro a poucas centenas de metros de distância - fenômeno nunca experimentado pelo homem moderno ${ }^{3}$, porém latente em seu imaginário, capaz de compreender a magnitude das consequências dessa pisada. Caberá a esta metafórica arqueologia nãohistórica investigar cientificamente vestígios (i)materiais do que podemos chamar pegadas de dinossauro. Tratam-se de evidências a rigor inexistentes, quase (ou propriamente) míticas e místicas, indecifráveis, uma Pippala do Rigveda ${ }^{4}$.

Os gigantes pré-históricos inspiram um dos momentos de análise do objeto deste estudo, os filmes do diretor norte-americano Terrence Malick - recipiente das divagações ou devaneios (para introduzirmos o termo do filósofo Gaston Bachelard, cujos estudos inspiram a fenomenologia aqui intentada) acerca do que chamaremos a seguir de teopoética. Em A árvore da vida (EUA, 2011), na longa sequência em que o cineasta recria os primórdios da existência material, Malick apresenta uma paisagem de dinossauros por uma narrativa peculiar. Não são meros co-habitantes do planeta, mas seres providos de graça e misericórdia. Um predador aproxima-se de sua presa, ferida, prostrada sobre um córrego. Com uma das patas, pressiona a cabeça do animal derrotado

\footnotetext{
${ }^{1}$ Optamos pela ilustração criacionista ancorada na tradição judaico-cristã descrita no terceiro versículo do livro bíblico de Gênesis ("E disse Deus: 'Haja luz', e houve luz) por interesse teopoético, como será observado ao longo do estudo.

${ }^{2}$ Debruçaremo-nos sobre esses conceitos nos capítulos a seguir.

${ }^{3}$ A afirmação nunca deriva dos estudos da origem das espécies de Darwin. Não descartaremos a possibilidade, contudo, da filosofia criacionista contemporânea à hipótese de que o homem civilizado teria convivido com dinossauros, segundo as evidências bíblicas dos monstros leviatã e beemote - a extinção se daria no momento pós-dilúvio.

${ }^{4}$ Segundo Bachelard, a árvore teria um duplo sentido: imanente e transcendente. A Pippala do Rigveda seria uma árvore "cosmogônica", tonificada e revivificada pelos princípios míticos dos sonhos (Dicionário de imagens, símbolos, mitos, termos e conceitos bachelardianos, FERREIRA, 2008, p. 29).
} 
e libera-o, imprime-lhe uma marca de benevolência. Desde o princípio, a gênese da vida flertava com seu criador. Embora restem as impressões dos fósseis para salvaguardar os anais da pré-história terrestre, buscamos resquícios etéreos - e eternos - no registro da película do cinema, tubo de ensaios escolhido por fins de pesquisa para a compreensão dos atributos teopoéticos do cinema de Malick. A luz refletida na luz; a claridade que obscurece e a noite que ilumina. Interessado em filmar sem refletores, recurso que tecnicamente se conhece por "luz natural", Malick arrisca muitos planos em contraluz, fotografia estourada e personagens em silhuetas dada a ausência da luz. Portanto, anelamos a bênção da treva, sem a qual o mundo eliminaria suas vogais e silenciar-se-ia em novo caos estrelado.

Uma vez cartografado esse percurso por meio de teóricos do cinema, da teologia e da filosofia a serem apresentados aos poucos (em nome do mistério do ser e da vida), incursionaremos pelos recônditos dos sonhos, dos devaneios e do instante poético de Gastón Bachelard, lugar onde luz e noite coabitam ambivalentes o mesmo tempo e espaço, se repelem e se beijam na mesma proporção.

Ela [a poesia] se desinteressa então por tudo que despedaça e que dissolve, por uma duração que dispersa ecos. Busca o instante. Necessita apenas do instante. Cria o instante. Fora do instante há somente prosa e canção. No tempo vertical de um instante imobilizado é que a poesia encontra seu dinamismo específico. (BACHELARD, 1994, p. 189)

O caminho escolhido para a jornada foi o da fenomenologia, cruzando algumas fronteiras entre a própria possibilidade dos devaneios bachelardianos da vontade - uma energia colocada a serviço da imaginação - e a ontologia de Martin Heidegger, o fenômeno marcado pela dualidade velamento-desvelamento, consideradas as duas possibilidades radicais da manifestação do ser. Vale elaborar um pequeno adendo de que o pensamento de Bachelard em toda sua obra, sobretudo no que chama de sonhos e de devaneios, parte de uma percepção do universo das imagens originais criadas pela mente humana a partir de um choque com a letra escrita - em alguns casos com a pintura ou a música. A sétima arte, em seu caráter de cinema-movimento, não está compreendido formalmente na teoria bachelardiana. A aproximação que faremos com seus devaneios parte de um entendimento de que o cinema como linguagem prescinde a mera criação de 
imagens automaticamente digeríveis e, portanto, permite ao seu espectador - do mesmo modo que a um leitor - a concepção de símbolos e artefatos imagéticos oníricos e pessoais para além dos planos e sequências.

O caminho para a compreensão do que convencionamos chamar de expedição segue percalços como os de uma viagem de mesmo fôlego sobre terra ou mar - sujeita a brisas e tempestades; planícies e vales. Antes do método formal, florescia o impulso poético. Explicamos melhor a cadência da pesquisa contando a seguinte história:

Ao apresentar os primeiros escritos acerca desta pesquisa sobre a obra de Malick para a banca de seleção do Programa de Pós-Graduação da FAC/UnB, as mais duras críticas envolveram a metodologia escolhida (por força do edital, que obrigava a descrevê-la, fora utilizada uma não apropriada) e a isenção do pesquisador, devido à fé cristã que professa. Sobre o primeiro aspecto, entendemos que a metodologia não precisa ser eleita de antemão, mas que pode vir espontaneamente, como o próprio mundo nascendo em combustão, por uma ótica evolucionista. Afinal, a consciência sobre o que de fato se está pesquisando permanece em processo de (re)construção. A fenomenologia encontrou esses devaneios em seus passeios pelo vão do estado de entropia onde repousam todas as coisas, banais e sábias. Acerca da profissão de fé, inseparável da cultura-ética-estética do pesquisador, a preocupação da banca seria o quanto a crença embaçaria o olhar científico que sustenta os pilares da razão no projeto acadêmico maior a ser alcançado após o percurso do mestrado. A resposta é simples. Eliminando as possibilidades de empreender um esforço científico na ordem da física quântica ou da teologia sistemática, e concluindo que não interessa para fins desta pesquisa investigar as origens do universo, vamos alçar ao desconhecido (ou ao Aberto, por uma ótica heideggeriana) uma leitura inspirada por uma bibliografia séria com finalidade de compreender como se manifesta o ser teopoeticamente no cinema de ficção, a salvo da ditatura do determinismo das ciências exatas e das prerrogativas bíblicas, entretanto, sem qualquer tentativa em negá-las. Um desafio, proposto pelo orientador, moldou a escrita e influenciou o método de investigação do estudo: construir artigos (que se tornaram ensaios redigidos buscando atender ao rigor acadêmico) cunhando um estilo em processo de composição rumo à conquista de uma teopoética. 
Antes de chegarmos a ela, nos cabe visitar algumas questões ligadas a espiritualidade e religião. Criaturas vivas que somos, animadas (dotadas de alma) carregamos a tríade emoção-razão-linguagem em nós - senão, como prefere Carl Jung, somos por ela carregados.

A espiritualidade não é algo que possuímos, que está em nós, mas ao contrário, nós é que estamos nela, ela é que nos possui com seu poder, sua força. (JUNG, 2011, p. 48)

Esse será um tema que merecerá atenção especial no capítulo 3. Prevemos tratar da espiritualidade/estado de espírito no contexto da "coreografia da adoração". Bachelard, ao analisar os escritos de Balzac, nos inspira a realizar correspondências entre o céu e a terra, "elemento fundamental da cosmologia balzaquiana". Tomamos emprestadas as relações da filosofia bachelardiana acerca da verticalidade encontrada no lirismo de Balzac para compreender a união entre o natural e o espiritual nos filmes de Malick. Quanto à religião, diante dessa evidência do transcendente, ela cumpre um papel mediador.

Religare é a palavra latina que origina o termo religião. Se se consegue a instância dessa religação, talvez se atinja o patamar mais complexo da relação entre o homem e a tanscendência. Atinge-se a potência mais radical, o universo dos "impossíveis", alcançados até hoje somente pelos místicos ou pela fantasia. (CASTRO, 2013, p. 22)

Assim, nos cabe encontrar uma cosmologia que tanto revele seu weltanschauung ${ }^{5}$ conferindo-lhe reflexão baseada nos símbolos recorrentes no cinema do elusivo cineasta Terrence Malick e como seu peculiar processo de construção da imagem corrobora o processo de análise da poesia no cinema, mas também pressupõe um impasse ao colocar o discurso sob uma ótica teológica. Como anteviu São Tomás de Aquino, no relato do dominicano Pie Duployé em sua tese de doutoramento (Estraburgo, 1964), a imagem pode ter valor fundamental para a compreensão do poético:

As realidades poéticas não podem ser compreendidas pela razão por causa de uma deficiência de verdade

\footnotetext{
5 O termo alemão foi cunhado pelo filósofo e etnolinguista alemão Wilhelm von Humboldt como definição de uma cosmovisão ou visão de mundo.
} 
que está nelas; as realidades divinas não podem ser compreendidas pela razão por causa de sua superabundante verdade. Realidades poéticas e realidades divinas, por razões opostas, são obrigadas a apelar para imagens. A relação que a teologia mantém com as imagens e a literatura de uma época define exatamente a relação que a teologia mantém com a cultura dessa época. Uma teologia sem imagens é uma teologia sem cultura. ${ }^{6}$

A teopoética permeia tanto as relações intersemióticas e interdisciplinares do campo científico, como fornece elementos problematizadores para o entendimento de uma teocentricidade na arte. $\mathrm{O}$ termo tem origem na academia americana. Mais precisamente, teria sido usado pela primeira vez em um discurso do poeta Stanley Romaine Hopper em 1971, na Society for the Arts, Religion and Contemporary Culture (Pennsylvania). Hopper também usaria o conceito de teomitologia, tendo principal interesse em encontrar traços da religiosidade na literatura secular. Algo que o teólogo alemão Karl-Josef Kuschel levaria ao limite, partindo da seguinte reflexão de Kurt Marti: "Talvez Deus mantenha alguns poetas à sua disposição" . Em sua pesquisa, Kuschel investiga os aspectos do discurso sobre divino e moral religiosa na literatura alemã contemporânea, passando por obras de Thomas Mann, Hermann Hesse e Franz Kafka, com sua inescrutabilidade do mundo.

Introduzimos, portanto, Deus. Esse elemento será recorrentemente referido ao longo das próximas páginas. No entanto, buscamos tratar a este nome (Deus) e também ao Diabo com um cuidado especial. Não há intenção de se colocar o registro deste theos como forma de compreender uma verdade absoluta. Ao referirmos a Deus, buscamos um sentido poético (ou teopoético) partindo de uma lógica que não consegue compreender toda a complexidade da manifestação do ser transcendental nas diversas culturas e matrizes religiosas. Vamos nos ater à específica tradição judaico-cristã. E esta escolha se deve tanto ao fato de um interesse particular na poética bíblica (que envolve desde a Torah judaica às cartas paulinas cristocentradas). Eis uma forma sucinta de explicarmos:

\footnotetext{
${ }^{6}$ São Tomás de AQUINO, Summa theologiae, g IIg, q. 102. a. 2, ad 2, cit. apud Pie DUPLOYÉ, La religion de Péguy, p. X-XII.

${ }^{7}$ Este é o titulo original do livro Os escritores e as escrituras: retratos teológicos-literários, de Karl-Josef Kuschel, que utilizaremos ao longo da pesquisa.
} 
Deus está no vento: vem, vai, não pode ser colocado em jaulas de papel ou de palavras (...) Depois que vai, a única coisa que resta é a memória de seu toque sobre minha pele. Eu só posso falar sobre isto: reverberações no meu corpo, assim que é tocado pelo vento; às vezes um frio, outras uma sensação de calor, arrepios... Não teologia. Poesia. Se você preferir teo-poética. (ALVES, 1991, p. 161)

Não estamos, portanto, buscando a Deus ou à sua natureza inspirada ou baseada nas concepções judaico-cristãs. Afinal, a ausência de uma teopoética engajada, defende Wilder, resvalaria em um encorajamento de pietismo evangélico ou de liberalismo inefetivo. Para Wilder, a teopoética surge como um termo discreto para se referir a um tipo de linguagem religiosa. E é isso que procuramos.

Teopoética é uma ativa e substancial perspectiva que gera uma linguagem capaz de revelar parte da natureza do divino neste mundo, facilitando enxergar as qualidades do divino no dia a dia. Não é prescritivo e não presume enjaular a totalidade da natureza de Deus. (KEEFE-PERRY, 2009, p. 590, tradução $\operatorname{nossa}^{8}$ )

De certa forma, no entanto, por um processo menos didático e mais onírico - para nos reaproximarmos a Bachelard -, propomos aqui fazer o mesmo com o conjunto fílmico de Malick, em conversas generalizantes com outras obras carregadas de elementos que permitem uma universalização da aplicação do conceito teopoética no cinema. Alguns deles são Luz de inverno (Ingmar Bergman, 1963), O sacrifício (Andrei Tarkovsky, 1986), A árvore dos tamancos (Ermano Olmi, 1978) e À meia-noite levarei sua alma (José Mojica Marins, 1964). Cada um deles contribui como "bibliografia", aparecendo como citações ou aparelhando os devaneios em questão. Permanece, contudo, Terrence Malick nosso eixo central do corpus da pesquisa. Portanto, antes de repassarmos capítulo a capítulo a proposta desta dissertação, servimos uma breve biografia do cineasta, seguida das sinopses de cada longa-metragem a ser analisado ao longo do projeto.

Depois de 17 de maio de 1979, após desertar da produção de Qasida or the beginning of the world, nunca mais seria publicada outra entrevista com o cineasta norte-

\footnotetext{
${ }^{8}$ No original: "Theopoetics is an active, embodied perspective, generating language that reveals some of the nature of the divine in this world, making it easier to see the divine in the everyday. It is not prescriptive and does not presume to have encapsulated the full nature of God".
} 
americano Terrence Malick como a que saíra nas páginas do jornal Le Monde nessa data, assinada pela repórter Yvonne Baby. Desde então, Malick carrega a fama - boa ou má a depender do momento histórico - de recluso. No set de filmagens, são raras as imagens do diretor em ação a se esgueirarem até um tablóide ou site cinéfilo. Afinal, embora misterioso, não ostenta popularidade digna dos paparazzi. O único livro que dá conta de biografá-lo chama-se One big soul: an oral history of Terrence Malick. Como o título sugere, o esforço do autor e editor, Paul Maher Jr., foi de catalogar os poucos depoimentos do cineasta e somar a entrevistas com familiares, amigos e pessoas que trabalharam com ele (produtores, fotógrafos, atores). Uma colcha de retalhos que serve a dois propósitos: publicizar a história do elusivo realizador e reforçar o mistério em torno de sua persona. Em 24 de outubro de 2007, o diretor chegou a comparecer a um encontro promovido pelo Festival Internazionale del Film di Roma. O público presente deveria seguir algumas regras, como não encarar o diretor ou mesmo endereçar-lhe alguma pergunta. Malick, diante de um projetor, apontou cenas de filmes caros a sua história, a exemplo de Juventude transviada (Elia Kazan, 1955), e proferiu pouquíssimas palavras sobre sua obra então mais recente, O novo mundo (2005).

Nascido na cidadezinha de Waco, estado do Texas (EUA), foi criado por seus pais com mais dois irmãos em Austin (também no Texas) e, depois, em Oklahoma. Filósofo formado por Harvard, abandonou sua bolsa de doutorado no Magdalen College em Oxford (Inglaterra) ainda no primeiro ano para trabalhar como repórter na revista The New Yorker. Nos oito meses em que permaneceu no periódico, assinou o obtuário de Martin Luther King e foi enviado para a Bolívia cobrir a guerrilha de Che Guevara, embora não fizesse muita ideia do que se tratava, segundo ele próprio. Encerrava-se sua carreira de jornalista. Seu maior interesse, no final dos anos 1960, se tornaria a filosofia, em particular a do alemão Martin Heidegger. Sua obsessão pela obra do filósofo existencialista o levou a aprender a língua germânica para traduzir um de seus livros para o inglês (The essence of reasons, Northwestern University Press, 1969). De volta aos Estados Unidos para lecionar filosofia no Massachussets Institute of Technology, em 1969, fez sua primeira incursão no cinema, sem qualquer pretensão, como parte do projeto final de um curso livre do American Film Institute. Batizado de Lanton mills, o curta-metragem tinha o próprio diretor como um dos personagens centrais, ao lado do já 
experiente Warren Oates. Trata-se de uma comédia ambientada no meio-oeste americano, sobre um mal-sucedido roubo de banco. A única cópia acessível repousa no acervo do instituto, em Los Angeles.

Brotou-lhe um gosto pelo fazer cinematográfico que o levaria a seu primeiro longa-metragem, Terra de ninguém (1973). Apenas cinco anos depois realizaria o segundo filme, Dias de paraíso (1978). No ano seguinte ao lançamento desse último, Malick começava e logo abandonava a produção de Qasida, concedendo sua última entrevista. Durante a década de 1980, viveu com a segunda esposa em Paris (França). Ao regressar para os Estados Unidos, embebecido pela leitura do romance Além da linha vermelha (1962), de James Jones, recriou a novela no filme poético-filosófico-religioso de mesmo nome, lançado somente em 1998 e que perderia o Oscar de melhor direção em 1999 para Steven Spielberg e seu par popularesco O resgate do soldado Ryan, também um registro da Segunda Guerra Mundial guiado pelo olhar dos combatentes. Sete anos depois, Malick retornaria aos cinemas, com a estreia de $O$ novo mundo (2005), uma releitura do romance da índia Pocahontas com o capitão inglês John Smith, quando da colonização da América. Somente em 2011, Malick consolidaria seu particular método de filmar - testando os limites das paisagens, do contraluz, do crepúsculo e dos elementos da natureza. Nascia $A$ árvore da vida, Palma de Ouro em Cannes. Contrariando a infâmia de "bissexto" (embora os espaços entre os filmes não tivessem a mesma regularidade), Malick anuncia (por meio do estúdio, claro) nada menos que três trabalhos em sequência: Amor pleno (2012), Cavaleiro de copas (previsto para estrear comercialmente em 2016) e Voyage of time (em fase de pós-produção para ser lançado também em 2016). Esse último, um projeto de documentário recuperado dos tempos de Qasida, nos anos 1970. Há um outro filme, ainda sem título, em que Malick trabalha. As duas décadas do novo milênio seguem prolíficas para o cineasta. Ele também assinou roteiros e assumiu produções de outros diretores, como A. J. Edwards (The better angels, 2014).

Terra de ninguém (Badlands, EUA, 1973, 94 min., Warner Bros./Pressman-Williams)

Custou menos de meio milhão de dólares - um incêndio acidental no set de filmagens onerou e atrasou a produção. Vencedor da Golden Seashell de melhor filme no 
San Sebastián Film Festival (1974) e indicado ao Bafta (1975) de atriz mais promissora (Sissy Spacek), o primeiro longa-metragem dirigido e escrito por Terrence Malick foi rodado no Colorado, porém ambientado na cidade de Fort Dupree, no estado americano de Dakota do Sul. Carregado de referências ao western e ao cinema americano e italiano em geral dos anos 1950, Malick filma o romance desajuizado de Kit (Martin Sheen), um gari que parece com James Dean, e Holly (Sissy Spacek), uma solitária adolescente de 15 anos que mora com o pai (Warren Oates) - a mãe falecera de pneumonia quando ela era ainda criança. A resistência do pai da garota em aceitar um namoro com o rapaz quinze anos mais velho leva a consequências trágicas. Kit o mata. Ainda assim, por amor, Holly embarca numa aventura, fugindo com ele da cena do crime até as montanhas (badlands) de Montana. Pelo meio-oeste americano, começa a apresentar o fetichismo das paisagens que marcaria seu estilo peculiar, aliado à narração em off da personagem feminina.

\section{Dias de paraíso (Days of heaven, EUA, 1978, 94 min., Paramount Pictures)}

Dotado de um orçamento ainda baixo, mas significativamente maior, US\$ 3 milhões, Malick trava uma da mais importantes parcerias para a sua poesia visual ao dispor do talento do espanhol Néstor Almendros como diretor de fotografia. Ele seria no ano seguinte reconhecido por esse trabalho com seu único Oscar. O desafio do cineasta para Almendros: filmar $100 \%$ do filme com luz natural. Essa escolha o levou a rodar cenas curtíssimas por vários dias, para conseguir criar a atmosfera crepuscular que permeia muitos dos momentos ao longo da trama. A história é sobre Bill (Richard Gere) e Abby (Brooke Adams), um casal que foge de Chicago após ele ter cometido um crime. A evidente semelhança com Terra de ninguém começa a arrefecer quando a dupla se passa por irmãos e começa a trabalhar para um rico fazendeiro (Sam Shepard) nos campos de trigo de Panhandle (Texas). Ao descobrir que ele teria apenas um ano de vida, Bill e Abby orquestram um golpe no qual ela seduziria o fazendeiro para casar-se com ele e, após sua morte, herdarem aquelas terras. Começa um jogo de ansiedade e ciúmes, cujo rumo é a tragédia. Nos plano abertos, Malick permanece (como em Terra de ninguém) buscando horizontes que potencializam seu interesse por mostrar a imensidão celeste. Linda, irmã caçula de Bill, assume a narração em off. 
Além da linha vermelha (The thin red line, EUA, 1998, 170 min., Fox 2000 Pictures)

A superprodução de Malick custou US\$ 52 milhões. Vinte anos depois do lançamento de Dias de paraíso, o diretor reaparece em Hollywood com esse ambicioso projeto e com o voto de silêncio diante da imprensa. Baseado no romance autobiográfico de James Jones, reconstrói a batalha de Guadalcanal, na Oceania, durante a Segunda Guerra Mundial. A guerra, contudo, não surge como principal eixo do filme, ao contrário de $O$ resgate do soldado Ryan (Steven Spielberg, 1998), também extraído da Segunda Guerra, pelo qual fora preterido no Oscar de 1999. Aqui, o aspecto universal do cinema poético de Malick ressoa com mais potência. A voz over não mais cumpre um papel somente narrativo, mas assume abertamente o caráter transcendental com o qual flertava nos trabalhos anteriores. O off flana entre os personagens, os soldados. Não há um protagonista claro, embora há estudiosos de Malick que atribuam esse papel ao Private Witt (John Caviezel). As vozes dos combatentes evocam questões espirituais e crises existenciais no meio do campo de batalha. A contemplação da natureza ganha mais atenção. Embora não mais pudesse contar com Almendros (falecido em 1992), o diretor de fotografia John Toll aderiu às exigências das tomadas sob luz natural de Malick.

O novo mundo (The new world, EUA, 2005, 135 min., New Line Cinema)

Esta produção de US\$ 30 milhões consolida o projeto poético-visual de Malick, graças à parceria com o diretor de fotografia mexicano Emmanuel Lubezki, que passa a assinar todos os filmes do cineasta (incluindo os ainda inéditos). A natureza rege esta recriação da história de Pocahontas (Q'orianka Kilcher), a nativa indígena que se apaixona pelo colonizador inglês Capitão Smith (Colin Farrell). A trama - guerra entre o homem branco e o índio - ocorre no segundo plano da narrativa flutuante das paisagens e sons da natureza que engolem os personagens, em longos e contemplativos quadros que abusam do contraluz e insistem em filmar diretamente o sol. 
A árvore da vida (The tree of life, EUA, 2011, 139 min., Cottonwood Pictures/River Road Entertainment)

Mais incensado filme do diretor. Custou R $\$ 32$ milhões que, como os demais, não foram recompensados na bilheteria, mas deu a Malick a Palma de Ouro de Cannes - a qual não foi buscar, naturalmente. Neste momento, ele cai por completo nas graças da crítica francesa, embora colecione mundo afora opiniões radicalmente divididas. Nesta história da família O'Brien, Malick revive fantasmas do seu passado pessoal - como o suicídio do irmão em terras estrangeiras -, porém espalhado em uma trama com propósitos de refletir sobre a criação do mundo, a cosmologia, o evolucionismo. Um dos momentos mais ousados apresenta uma sequência de quinze minutos, na qual o diretor confere sua interpretação poética sobre o início de todas as coisas e a vida terrestre.

Amor pleno (To the wonder, EUA, 2012, 112 min., Redbud Pictures/Brothers K Productions)

Pela primeira vez, Terrence Malick trabalharia em dois projetos quase que simultaneamente. Em um espaço de apenas um ano após lançar $A$ árvore da vida, estreou este filme de amor. Amor em dois sentidos: o carnal, de Neil (Ben Affleck) com a imigrante Marina (Olga Kurylenko) e com a ex-namorada Jane (Rachel McAdams); e o espiritual, refletido sobretudo na relação entre Padre Quintana (Javier Bardem) e Deus. A conexão espiritual, contudo, atinge todos os demais personagens, principalmente no desencadear das crises metaforizadas pelo adultério do profeta bíblico Oséias. Afinal, Neil esfria o comprometimento com Marina ao tempo em que ela tem seu visto expirado. Ambos se voltam a Deus por socorro, intermediados pelo padre. Contudo, o sacerdote experimenta um momento frágil de sua fé, despedaçada.

\section{Capítulos}

Antes de mergulharmos nas questões apresentadas acima, repassemos o conteúdo da presente dissertação, dividida em cinco capítulos, incluindo as considerações finais, formando uma coleção de pequenos ensaios. No primeiro capítulo, estabelecemos os 
primeiros parâmetros teóricos, acerca do tempo vertical em Bachelard. Em questão, pensaremos em como podemos conjugar as distintas noções transdisciplinares envolvidas na dissertação rumo à conquista de uma teopoética. Em seguida, no segundo capítulo, desenvolveremos hipóteses em dois sentidos: da narrativa ficcional e da questão filosófica do ainda-não-ser, partindo da utopia de Bloch, em um paralelo com o texto bíblico sobre o caminho para Emaús, em que também pontuaremos algumas ideias acerca de ausência e presença. Convidamos Heidegger para iluminar a questão ontológica tendo como ponto inicial sua ideia de pre-sença para então desenvolvermos um pensamento a partir de metáforas acerca da imagem-percepção de Gilles Deleuze. Concluímos o capítulo observando o que temos chamado de traços do invisível, pontuando noções de desenquadramento transcendental e os recursos técnicos que fornecem subsídio para percepção da imagem. No terceiro capítulo, reconheceremos os aspectos relacionados ao amor em Malick: a ordem cerimonial com a qual trata sua trilha sonora diante da ação e da contemplação; o simbolismo dos gestos, em diálogo com o artigo de Saad Chakali sobre a beleza do gestual nos filmes de Malick, a captura dos primeiros e segundos planos (a natureza mediadora), os close-ups das mãos e dos toques como sinais de adoração. Elevação dos olhares aos céus, regada pela contraluz e as brincadeiras lúdicas das crianças e dos casais, compondo o que Laurent Guido chamará de "ritmos do romantismo pastoral americano". O quarto capítulo, batizado de "Soli Deo gloria", buscará refletir sobre o rito da paisagem e o mito revelado, questões relativas à construção poético-visual dos filmes, e questões morais, éticas, estéticas e transcendentais na obra de Malick, segundo os dilemas espirituais dos seus arquétipos. 


\section{No horizonte, a estrela d'alva}

"A poesia recusa a dúvida. No máximo, tem necessidade de um prelúdio de silêncio. De início, batendo em palavas ocas, faz calar a prosa ou os trinados que deixariam na alma do leitor uma continuidade de pensamento ou de murmúrio. Depois, após as sonoridades vazias, produz seu instante"

Gaston Bachelard 
Segundo a tradição judaica, a intermitente aparição de Vênus no céu sinalizava profecias, nascimentos de governantes e grandes acontecimentos. A ciência moderna, desde Galileu Galilei no século XVII, investiga os mistérios da tão brilhosa estrela que constela tangente ao sol da alvorada. Desvendou-se seu lugar no sistema solar e as idiossincrasias de sua atmosfera. Ainda é possível enxergar o planeta a olho nu - se é que resta encanto para tal ato prosaico de ver estrelas na atualidade. Um sem-número de aplicativos tecnológicos gestados pelas novas mídias comunicacionais poderiam ser capazes de levar seu observador para muito mais próximo desse planeta. Para ir além, entretanto, precisariam transcender.

A característica mais marcante de Vênus surge a reboque de sua pecha: estrela d'alva. Afinal, seu brilho reluz de dia. Por isso, evocamos essa estrela para conduzir-nos nesta reflexão, tal como fizera ao levar os reis magos até Cristo, ao prenunciar a queda do rei da Babilônia por volta do ano 700 a.C. e ao permitir à mitologia romana representarse em sua formosura incorpórea nos traços da deusa da beleza. Esse brilhar em meio à luz, metaforizado pela essência da estrela da manhã, circunscreve-se como receptáculo para as divagações que nos levam a estimular um olhar sobre o universo, a natureza, o homem e suas relações com o divino a partir não do real, mas de uma percepção da realidade que pode ou não ser construída por meio da ficção. Ao trazermos a ficção para perto - daí a escolha por esta experiência -, suscitamos uma urgência por dialogar com a arte, veículo da materialização de uma transcendência capaz de "gerar Deus", utilizando uma expressão cunhada pelo poeta austro-húngaro Rainer Maria Rilke.

Se o homem busca formas espirituais de mediação para alcançar uma compreensão divina, na ficção Deus precisa da mediação humana para ser encontrado. Isso é, naturalmente, paradoxal, uma vez que o Deus da ficção brota de uma compreensão do Deus da experiência imanente - ainda que invisível, porém, real, presente no discurso dos lábios daqueles que o professam, das religiões, dos adoradores. $\mathrm{O}$ ato de gerar Deus é, para a arte, uma consequência do chamamento do homem à poesia (ou a algum tipo de exercício poético), um convite à elevação, revigorando seu caráter transcendental (CASTRO, 2013). A palavra Deus, em sua etimologia judaico-cristã e até conforme o latim, é associada à presença de luz, ou à própria claridade em si. A estrela d'alva é uma 
de suas metáforas: "permite ver" (Ibid.) ou "torna a ver por um potencial autotranscendente" (SANTOS, 2006, p. 15).

Daí empreendemos a busca pela verdade. Não a verdade da razão nem a máxima da origem de todas as coisas. Mas o que Tarkovski chama de a "própria verdade" (2010, p. 99-100). Achá-la é encontrar uma linguagem específica, um sistema de expressão destinado a dar forma a ideias pessoais. Aqui, o cineasta e poeta russo se refere ao cinema - embora seu interesse seja o de fazer uma crítica construtiva à história da sétima arte de dentro para fora, não por meio de acontecimentos e marcos, mas do pensamento do próprio artista. Trazemos justamente o cinema para aleitar, rocha sobre rocha, os parâmetros desta experiência de alcançar um entendimento sobre Deus, enquanto criadorcriatura gerado pelo homem a partir da arte, ou mais especificamente do chamamento poético de Castro, que pode advir da contemplação da linguagem.

Não buscamos a representação de Deus, mas a humanindade inserida em um cosmo, o transcendente no sentido heideggereano de imbricamento do ser com o que há de mais originário no homem. Para isso, seria fundamental investigar autores de cinema cujos pensamentos con-vocam a participar, seja na imanência, seja na transcendência ou na problematização das relações entre ambas -, da realidade e dos mistérios da verticalidade: "Compete cada homem sentir na intimidade a força do sagrado" (CASTRO, 2013 , p. 51). Essa perspectiva vertical - capaz de se elevar e de se afundar, ao tempo em que a horizontalidade, achatada, se apaga - experimenta em Bachelard uma crise do tempo, pedra angular do instante poético, "lugar" de onde partiremos para encontrar essa teopoética. Não o faremos por ato da fé ou religiosidade, por esse dizer respeito a impulsos eclesiásticos individuais, portanto próprios de um uso privado da razão, que ainda, em seu momento, poderá nos interessar. O esforço inicial dessa busca reside na pretensa possibilidade de se desvendar os mecanismos poéticos que podem disponibilizar pistas da manifestação da transcendência divinal no cinema.

Há de se fazer a distinção entre o caminho da transcendência e o caminho que leva a Deus. O primeiro desempenharia uma função de princípio condutor da inferência pretendida (PEIRCE, 2010, p. 5). O segundo seria a premissa apaziguadora (por enquanto) segundo a qual escolheremos o objeto para ascender a uma abdução 
teopragmaticista. Adjetivamo-na teopoética, na qual a poesia está indissociada dos aspectos do divino ou por considerar uma estilística do discurso adequado para se falar de Deus nos dias de hoje.

Os filmes de Terrence Malick, o elusivo cineasta norte-americano avesso a entrevistas e a aparições públicas (nem mesmo para receber láureas, como a Plama de Ouro em Cannes), compõem um conjunto peculiar de narrativas/discursos que podem, com efeito, abranger o conceito esmiuçado por Kuschel no universo literário para uma percepção que podemos caracterizar inicialmente como sensório-motora, para recorrermos a um termo de Deleuze que indica, grosso modo, um caráter prosódico da narrativa cinematográfica. Ao nos referirmos a um discurso cinematográfico, evocamos, portanto, não somente o roteiro, os diálogos, a narrativa, mas, como na literatura, princípios estilísticos próprios da sua linguagem. No caso da audiovisual, elementos como voz over, enquadramento, close-up, trilha sonora, mixagem de som, efeitos especiais, fotografia, montagem etc.

Antes de análises dos requisitos técnicos, porém, interessa mais a esta expedição as questões relativas ao tempo (verticalidade) e ao ser (justificação). Essas duas insígnias filosóficas compõem o bojo dos principais mistérios poéticos escondidos no ainda indecifrável horizonte desta jornada - uma vez que carregam consigo, em ambivalência, a antítese, a androginia, camadas do fenômeno exemplificado por Bachelard do pesar sorridente: polos ambivalentes no limite, a ponto de quase tocarem-se ou mesmo a substituirem-se um ao outro. Eis a questão do tempo vertical.

No fundo de seus olhos adoráveis, vejo sempre a hora distintamente, sempre a mesma, uma hora vasta, solene, grande como o espaço, sem divisões de minutos ou de segundos - uma hora imóvel que não é marcada pelos relógios... (BACHELARD, 1994, p. 186)

Nesse trecho extraído dos Petits poèmes en prose de Baudelaire, Bachelard ilustra sua percepção do instante poético, embora não o limite. Torna-se essencial para o desdobramento de uma compreensão de poesia levar a questão para além das limitações de gênero e de linguagem. Marcondes, em sua dissertação sobre o chamado filme-poema Limite, de Mário Peixoto, consegue, com efeito, superar esse dilema de uma legislação $a$ 
priori do fazer poético, ajudando-nos a derrubar barreiras formais para conferir liberdade à inferência.

São imagens de cinema, e a imagem talvez não possua a referenciação a partir do deslocamento de símbolos que percebemos quando tentamos entender a linguagem escrita. Imagens são imagens, presas a um autotelismo talvez indecifrável para as palavras. (MARCONDES, 2008, p. 109)

Tal como Kuschel observara em Herman Hesse (generalizando para os escritores alemães contemporâneos), em Malick o caminho para uma teopoética começa com as escolhas estéticas do discurso sobre Deus e do modus operandi do orador, que se relacionam com uma realidade, provocam uma crise de alteridade e se revelam sob a forma do encontro.

O discurso sobre Deus ocorre nos limites extremos das possibilidades da linguagem, sob a consciência de que o não-saber constitui fundamento e resultado de toda a dicção sobre Deus e de que tal dicção só se consuma na dialética entre a fala e o silêncio. (KUSCHEL, 1999, p. 225)

Antes de posicionar-se como autor de cinema, Malick assume uma oratória de pregador em um sentido pseudoreligioso. Há, no centro do discurso imagético de Malick, uma expectativa do devenir, aquém da realização cinematográfica, mas que reside no anseio justamente do ser - "o sujeito falante é todo o sujeito", diria Pontalis (FERREIRA, 2008, p. 98). No caso particular de Malick, há elementos de experiências pessoais como nostalgia, história e crença que provocam a interação entre o plano real de vida do autor na obra fictícia, mesmo não havendo interesse biográfico. A postura de Malick, porém, busca a transcendência desse devenir no limite.

Em Malick, essa verticalidade é, ao mesmo tempo, prosódica e poética. Porém, com regularidade, também poética enquanto prosódica - "desde que aceite as consequências do instante poético e possibilite reunir a prosa, o pensamento explicado, os amores experimentados, a vida social, a vida corrente, a vida deslizante, linear, contínua" (BACHELARD, 1994, p. 184). Atos conscientes, amparados pela câmera paciente e silenciosa do diretor, recusam o artifício do corte, buscam a luz natural obsessivamente e invocam a "onipresença do som", conforme o próprio Malick descreveu durante a última 
entrevista concedida por ele, ao Le Monde, em maio de 1979. Quanto ao corte, é notório o longo tempo no set de filmagens a que a equipe do cineasta é submetida. Capricho ou idiossincrasia, juízos de valor à parte, colegas de estúdio costumam dizer que Malick filma mas não corta, pois aguarda reações da natureza, como acompanhar uma borboleta incidental ou capturar a brincadeira dos atores-mirins no gramado para encontrar os simbolismos dos gestos, das expressões e, claro, aproximar/confrontar natureza e humanidade mesmo no bastidor da realização. É, talvez, um fetiche por encontrar uma aura, no sentido benjaminiano, ou simplesmente o chamamento da estrela d'alva a esticar mais um horizonte 9 .

\subsection{Sopro do espírito: a voz da devoção}

Som. Onipresente por si próprio. Revestido ou travestido de transcendência. A síntese pensamento-som ${ }^{10}$ nos municia a configurar uma poética particular do cinema de Terrence Malick relacionada a uma das mais primitivas facetas da linguagem audiovisual: a voz over. Bosi oferece a reflexão de que som e pensamento transcenderiam a língua. "No poema, força-se o signo para o reino do som" (1997, p. 39). Transbordante, a poesia de Malick busca igualmente silêncios e o que Bosi define como fenômeno verbal, referindo-se às formas de se franquear o intervalo que faz a mediação entre corpo e objeto. A palavra desempenha, no cinema de Malick, função estética e também divinal (em um sentido inclusive religioso, com ênfase na tradição judaico-cristã). Não tenta, contudo, tratar da força do imaginário, do símbolo. Buscamos entender como o verbo na obra do diretor norte-americano concerne ao ser em um tempo que não lhe é próprio.

Algumas marcas de estilo revelam que não há apenas poesia na intenção verbal de Malick, mas uma presença devocional, uma forma de evocação (ou invocação) da divindade. Com efeito, uma questão primeiramente literal deve ser analisada. Ao absorver fundamentos bíblicos para construir as premissas básicas de sua narrativa, Malick anuncia abertamente uma crise de experiência espiritual. Em $A$ árvore da vida

\footnotetext{
${ }^{9}$ Referência ao ato lúdico-poético de esticar horizontes. Ver em BARROS, Manoel de. Poesia completa. São Paulo, Leya, 2010, p. 322.

${ }^{10}$ Embora o conceito original derive de uma psicanálise da linguística de Saussure, vamos aqui usar como ponto de partida para a reflexão as ideias de Bosi acerca deste díptico.
} 
(2011) cita-se passagem do livro de $J o ́$ em que Deus reclama sua autoridade onipotente diante da insignificância dos murmúrios de Jó como prólogo da jornada de uma família tradicional do meio-oeste americano - uma metáfora da complexidade da formação da existência terrena, da origem de todas as coisas.

Quem está a denegrir a providência

Com discursos sem sentido?

Cinge, como um valente, os teus rins,

Vou te interrogar e tu me instruirás.

Onde estavas, quando eu fundei a Terra?

Dize-me isso, sábio que és.

Sabes quem fixou-lhes as medidas?

Quem estendeu sobre ela o cordel?

Em que imergem as suas colunas,

A pedra angular, que a lançou,

Ao canto coral das estrelas matutinas

E à aclamação dos Filhos de Deus?

(BÍBLIA, Jó 38:1-7)

O que se apresenta na narrativa é a frustrante jornada de um inventor, Mr. O'Brien, fracassado em seus atributos profissionais e paternos, finalmente rendido à pequenez do profeta Jó nesta passagem em que Deus o admoesta com rigor.

Amor pleno (2012) recorre a várias menções eclesiásticas de modo a refletir o estado espiritual de cada personagem. O adultério da esposa do profeta bíblico Oséias e sua insistência em permanecer casado com ela metaforizam as inconstâncias do relacionamento conjugal de Neil (Ben Afleck) e Marina (Olga Kurylenko) e a crise de fé do padre Quintana (Javier Bardem) em sua aliança com Deus. Além da linha vermelha incorpora a fé cristã de modo menos descritivo, porém vai imbuir de um espírito devoto os soldados no front de batalha. Na voz over de Private Edward P. Train (John Dee Smith), ouve-se: "Onde era que estávamos juntos? Quem eras tu com quem eu vivi? O irmão. O amigo. Escuridão, luz. Luta e amor. São esses atributos de uma mente? Facetas de um mesmo rosto? Ó, minha alma. Deixe-me ser em ti agora. Olhe pelos meus olhos. Veja as coisas que criastes. Todas as coisas brilhantes." Por mais que a questão 
concernente ao existencialismo de Heidegger influencie a voz over de Malick, as implicações deste recurso narrativo propõem uma relação imbuída na poesia entre homem e Deus - neste caso, como na maioria da obra de Malick, o Deus cristão.

$O$ novo mundo também persegue uma mediação nos relacionamentos dos personagens imanentes com o sagrado por meio de seu off. Pocahontas (Q'orianka Kilcher), em suas orações, objetiva um relacionamento com a Mãe Natureza: "Mãe, onde tu vives? No céu? Nas nuvens? No mar? Mostre-me seu rosto. Mande-me um sinal. Levantamo-nos... levantamo-nos. Com medo de mim mesma. Um deus, ele me parece. O que mais é a vida se não ficar próxima a ti? Eles suspeitam? Ó, ser entregue a ti. Tu a mim. Eu serei fiel a ti. Verdade. Não mais dois. Um. Um. Eu sou... eu sou.” Num misto de prece com declaração de amor, o conteúdo da mensagem de Pocahontas apresenta uma leitura não do nativo americano, indígena, mas preceitos teológicos da matriz católica conservadora são recorrentes, como a noção de casamento ("e os dois se tornarão uma só carne", em Marcos 10:8).

Os dois primeiros filmes, Terra de ninguém e Dias de Paraíso, elaboram um discurso mais sugestionado acerca da relação dos personagens com a experiência religiosa, incorporando questões morais à narrativa, embora não ignorando um potencial transcendente de seus personagens e cenários por meio, sobretudo, daquilo que une toda a filmografia de Malick: o off.

Os primeiros filmes empregam uma narração no pretérito perfeito, posicionada suficientemente logo após os eventos que cada adolescente feminina narra retendo suas perspectivas, com imatura voz física uma compreensão limitada. A maior parte da narração no tempo presente nos filmes mais recentes, enunciando pensamentos, preces, cartas, diários, memórias e diálogo não vistos, evocam a complexa nostalgia dos filmes e um corriqueiro estado de intemporalidade, sem interrupção da fluência narrativa. (MCLEOD, 2009, p. 57-58, tradução nossa ${ }^{11}$ )

\footnotetext{
${ }^{11}$ No original: "The early films employ a past tense narration, positioned sufficiently soon after the events that the teenage women narrating each film retain their perceptive and comprehensive limitations and immature physical voice. The largely present - tense narration of the later films, with the voice over enunciating thoughts, prayers, letters, journals, memories and unseen dialogue interchangeably, evoke the films' complex nostalgia and often a state of apparent timelessness, without interrupting narrative flow".
} 
De outro lado, compondo o segundo traço de finalidade da voz over, o recurso aplicado se justapõe a uma câmera vagarosa, ao excesso dos feixes de luz e, sobretudo, a uma estrutura narrativa por vezes complexa, permitindo leituras que perpassam a experiência visível. Exige-se do espectador uma atitude de fabulação, se seguirmos os instintos do duplo devir de Deleuze.

A fabulação não é um mito impessoal, mas também não é ficção pessoal: é uma palavra em ato, um ato de fala pelo qual a personagem nunca para de atravessar a fronteira que separa seu assunto privado da política, e produz, ela própria, enunciados coletivos. (DELEUZE, 2010, p. 264)

Naturalmente, o contexto de Deleuze abordava algo específico. Tratava de uma reflexão acerca de uma postura cinematográfica com nítido objetivo de criar intercessores, de "ficcionalizar" personagens reais. No entanto, nos interessa essa leitura. Afinal, no cinema de Malick - em especial de $A$ árvore da vida - há uma forte presença da ficcionalização. Se em Terra de ninguém Malick voltou ao cenário de sua infância (a cidade de Waco, Texas, nos EUA), em A árvore da vida ele toca em um ponto sensível de sua história pessoal: o suicídio do irmão caçula, Larry, após frustrar-se com sua carreira, como descreve o jornalista Peter Biskind em "The runaway genius", na revista Vanity Fair:

Larry, o mais novo, foi para a Espanha estudar com o virtuose do violão Segovia, um professor cujo rigor era lendário. No verão de 1968, Terry (Malick) soube que seu irmão havia quebrado as próprias mãos, aparentemente enlouquecido com seus estudos. O pai pediu que Terry fosse à Espanha ajudar Larry. Terry se recusou. Emil [o pai de Malick] foi, e voltou com o corpo de Larry. Aparentemente, ele cometera suicídio. Como a maioria dos parentes de pessoas que tiram a própria vida, Terry deve ter carregado um fardo pesado de culpa irracional. (BISKIND, 1998, p. 206, tradução nossa ${ }^{12}$ )

\footnotetext{
12 No original: Larry, the youngest, went to Spain to sudy with the guitar virtuoso Segovia. Terry discovered in the Summer of 1968 that Larry had broken his own hands, seemingly despondent over his lack of progress. Elim [Malick's father], concerned, went to Spain and returned with Larry's body; it appeared the young man had commited suicide. Like most relatives of those Who take their own lives, Terry must have borne a heavy burden of irrational guilt.
} 
"As freiras nos ensinaram que existem dois caminhos para se atravessar a vida: o caminho da natureza e o caminho da graça." A voz over de Mrs. O'Brien (Jessica Chastain) no prólogo de $A$ árvore da vida pode carregar em si o cerne da problematização de Bachelard acerca do instante poético: "É essencialmente uma relação harmônica entre dois contrários" (BACHELARD, 1994, p. 184). No caso de Malick, apresentam-se diversas camadas: a luz que obscurece, a voz que fala o que o olho não vê e a paisagem oculta na narrativa. Atemo-nos, nese momento, a investigar o fenômeno da voz.

Popularmente, o dispositivo do off atende pelo nome de "voz de Deus". Michel Chion vai acrescentar o termo francês acousmêtre. "Desamarra-se do corpo de onde a voz emana e, portanto, tem uma variedade mais abrangente de poderes para tanto aumentar ou perturbar a maestria epistemológica do enredo visual do filme". (CHION, 1999, p. 112). O fenômeno do acúsmetro, como fora empregado nas traduções ao português, ocorre com frequência nos filmes de Malick.

Em momentos de culto, missa, nos quais o porta-voz é o pregador, encontramos exemplo adequado. Há pistas tão ou mais assertivas às pisadas de bota ouvidas fora do quadro, como Chion usara de ilustração para um entendimento prático do acúsmetro. A igreja surge em tela construída por meio das imagens de vitrais, símbolos religiosos corriqueiros facilmente assimiláveis pelo imaginário coletivo. Afora esses, ainda ouve-se o conteúdo da mensagem e a homilética desempenhada pelo orador. Imediatamente, não é possível reconhecer quem é de fato aquele personagem. Aos poucos, a voz se personifica. Em Amor pleno a fala torna-se importante para apresentar o padre Quintana, um personagem relevante à trama, de certa forma um protagonista - sobretudo se pensarmos no filme como se inserido na estrutura de narrativa de rede, devido aos três núcleos e arcos dramáticos muito claros formados ao longo do filme. A árvore da vida tem em seu pregador um adereço para corroborar o processo de luto experimentado pela família O'Brien e compartilhado com o sofrimento da morte de um garoto da comunidade. O novo mundo realiza este acúsmetro cerimonial para apresentar o chefe da tribo indígena, Powhatan (August Schellenberg). A voz (em dialeto algonquino) corresponde à do nativo, mas a leitura imagética a ser feita daquelas palavras recai sobre a apreensão do capitão Smith (Colin Farell) tomado por refém. Eis a camada litúrgica da voz em off: valorizar de dentro para fora uma atmosfera ritualística, cuja função conjuga 
o desejo de conferir importância ao setting da trama com uma postura de reforçar a impotência do personagem central da trama: Mr O'Brien (Brad Pitt) comparece ao velório do garoto que não conseguira salvar em $A$ árvore da vida; estampa-se o embaraço do casal em vias de separação de Amor pleno; e mantém-se Smith, de O novo mundo, em postura de suspeição e encanto (pela formosa Pocahontas).

Uma outra extensão da voz off em Malick concerne ao tom. Holly (Sissy Spacek) em Terra de ninguém e Linda (Linda Manz) em Dias de paraiso vocalizam sua narração com uma melodia quase infantil, insegura e lúdica (ainda que contem histórias de violência). A utilização da potência vocal por Malick em Além da linha vermelha ganha mais complexidade devido à múltipla narrativa. Os offs se confundem entre os personagens inicialmente. Conhecemos suas vozes e suas expressões em momentos distintos. Exige-se um pouco de paciência para se identificar os donos das vozes. Este exercício de Malick cria um paralelismo narrativo entre imagem e som. É possível criar empatia pela voz do soldado Witt - suas ideias, sonhos e preces - antes de se envolver com seu arco dramático, que culmina em sua deserção e seu relacionamento com os nativos da ilha de Guadalcanal. O relacionamento de Pocahontas e Capitão Smith em $O$ novo mundo transcorre também por meio de inferências em off de ambos os personagens em diálogos com a Mãe Natureza e Deus acerca um do outro; e Árvore da vida nutre a sua personagem central, Ms. O'Brien (Jessica Chastain), de dotes angelicais. O caminho da natureza (duro, imanente, irascível mimetizado na figura de Mr. O’Brien) e o caminho da graça (do amor, da piedade). A fala de Ms. O'Brien soa como melodia angelical em seu sussurrar de preces. A saber: este recurso do off para exprimir as orações dos personagens vem sendo utilizado por Malick, com efeito (no sentido de referendar abertamente o divino), desde Além da linha vermelha. A rigor, o faz como se essas vozes tão atônitas, descompassadas, trêmulas e sussurrantes experimentassem crises heideggerianas profundas. Marina (Olga Kurylenko), em Amor pleno, observa o colapso de seu casamento com Neil (Ben Affleck). Como em sonho, sua voz narra em linhas poéticas e proféticas os conflitos sugeridos no subtexto do roteiro. "Existe um amor que é como uma nascente, que seca quando a chuva já não alimenta", diz ela. $\mathrm{O}$ acúsmetro aqui pretende ir além das pisadas das botas. 
Os poderes são quatro: habilidade de estar em todo lugar, ver tudo, saber tudo e ter poder completo. Em outras palavras: ubiquidade, panoptismo, onisciência e onipotência. O acúsmetro está em todo lugar. (CHION, 1999, p. 24, tradução nossa ${ }^{13}$ )

Pesquisador muito dedicado à obra de Malick, Steve Rybin apontará outra questão temporal curiosa na narrativa do diretor, como faz ao exemplificar a disjunção entre o que é visto em tela e o que é ouvido. Holly (Sissy Spacek) em Terra de ninguém, por exemplo, narra eventos vistos no filme de um lugar desconhecido que será apresentado em algum ponto em um futuro próximo da trama, como observa Rybin. "A lacuna entre realidade visível e vocalizada nos filmes de Malick gera mais um sentido de ambiguidade temática do que de certeza epistemológica” (RYBIN, 2012, p. $21^{14}$ ).

Holly experimentará as duas camadas do uso de voice over de Malick. Uma delas não deixa de ser a descrita acima, de um deslocamento da imagem-tempo deleuziana, en que o caráter onírico da mensagem transcende a imagem bruta da tela, provocando ao espectador uma infidelidade da imagem colocada. Ao longo de sua jornada, a voz de Holly começa uma busca existencial, na qual desliga-se da aventura sonhada para uma introspecção guiada pela razão, direcionada a um autoconhecimento.

A técnica prosaica encontra consonância com o discurso poético. Convivem os movimentos da alma e as leis físicas da gravidade - recursos aprimorados a partir de Além da linha vermelha, quando Malick deixa sua resistência pela câmera na mão para assumí-la de modo muito particular, em suaves movimentos pendulares. Com isso conquista planos que rejeitam classificações e que buscam recortar o enquadramento fora das categorias preestabelecidas do cinema clássico (plano americano, close-up etc.). Consiste em seguir a imagem em movimento de flutuação volúvel, sem compromisso com a firmeza do solo ou a insondabilidade do céu. Com efeito, as opções herméticas dos quadros do cineasta corroboram para a eficiência deste processo de ocultação (via acúsmetro ou não) do lugar da voz.

\footnotetext{
${ }^{13}$ No original: "The powers are four: the ability to be everywhere, to see all, to know all, and to have complete power. In other words: ubiquity, panoptidsm, omniscience, and omnipotence. The acousmetre is everywhere".

14 No original: "The gap beetween visible reality and voiced, retrospective meaning in Malick's filmes generates thematic ambiguity rather than epistemological certainty".
} 


\subsection{Dilemas da gravidade e o sonho de voo}

Uma primeira conclusão acerca da problemática do instante poético no cinema de Terrence Malick começa a se desenhar com essa característica peculiar do movimento de câmera perpetrado pelo cineasta, um artifício sistemático usado desde Além da linha vermelha (1998) e que, como tal, traduz-se após sua recorrência em estilo fílmico "instrumento de generalização e de classificação", segundo Bordwell, ou "função individuante, pensado como qualidade", conforme Burch (AUMONT e MARIE, 2003, p. 109). Ambas as leituras (sobretudo a sobreposição delas) satisfazem nosso objetivo, que transcende um debate envolvendo as minúcias da conceitualização técnico-teórica do olhar da teleobjetiva. Tateamos uma tessitura de ordem teopoética.

Aprofundando a noção do estilo por uma outra ontologia que não a da teoria do cinema, mas passando pela doutrina da imaginação material de Bachelard, podemos perceber que determinados movimentos de câmera de Malick - conduzida pelos diretores de fotografia Néstor Almendros (1930-1992), John Toll e Emmanuel Lubezki - não estão condicionados aos planos, mas tentam revelar um dinamismo próprio. Por este motivo não foram relacionados acima os fotógrafos que assinam a cinematografia de Terra de ninguém. Ali, a fotografia é mais estável e apresenta propostas que nos interessam desenvolver mais adiante. Neste momento, a partir de Dias de paraiso, passamos a notar um movimento duplamente vertical. A primeira é a verticalidade bergsoniana, tecnicista, que depende de uma manipulação física do enquadramento, no qual o olho-tela percebe o deslocamento da imagem de acordo com o que se tenta mostrar, subindo e descendo o equipamento conforme a necesidade de estar mais ao céu ou mais à terra; mostrar mais a cabeça ou os pés. Um fenômeno de translação que sacia os anseios de ordem do movimento, da imagem-ação, objetiva e difusa. Vamos nos ater à segunda verticalidade.

Ao nos aproximarmos das cidadelas da não-ciência do Bachelard noturno aquele que rompe com o epistemólogo fenomenotécnico diurno, temeroso das metáforas, da ambiguidade, e protetor do racionalismo -, podemos propor a superação da imagemmovimento bergsoniana (da qual Deleuze trata ao construir sua teoria cinética e cinéfila de um cinema de qualidade sensório-motora) e percorrer caminhos para desvendar o mistério poético. Partindo do Bachelard noturno, esse mistério é uma androginia, 
resultado de uma verticalidade que é verticalizante, de um tempo poético em contraposição ao da prosa e da canção - e não significa que toda poesia exerça ou seja vertical. A verticalidade bachelardiana da qual falamos pretende-se uma teleologia da elevação, interessada em buscar as coisas do alto... "O tempo vertical se eleva. Por vezes também afunda" (BACHELARD, 1994, p.186).

A técnica prosaica supera sua mera andadura ao encontrar consonância com o discurso poético nos filmes de Malick. Convivem os movimentos da alma e as leis físicas da gravidade - recursos aprimorados a partir de Além da linha vermelha, quando Malick deixa sua resistência pela câmera na mão para assumi-la de forma muito particular, gravitacional. São planos que rejeitam classificações e que buscam recortar o enquadramento fora das categorias preestabelecidas do cinema clássico (plano americano, close-up etc.). Consiste em seguir a imagem em movimento de flutuação volúvel, sem compromisso com a firmeza do solo ou a insondabilidade do firmamento.

Neste pendular gravitacional da câmera de Malick está mimetizado o encontro das forças naturais e divinas. Da mesma forma como arrasta-se em direção ao solo, o plano levita sem firmeza aparente. Invoquemos, a título de metáfora, a teodiceia narrada pelo evangelista João sobre o encontro de Jesus com os discípulos. Cristo andava sobre as águas. A impressão inicial da imagem do mestre transgredindo a volatilidade da água era fantasmagórica. Cristo convida Pedro - o pescador-discípulo cuja etimologia do nome deriva de pedra - a deixar o barco em alto mar e acompanhá-lo no solo líquido. Seus primeiros passos de fé demonstram a firmeza de sua vocação a rocha. Logo, a fé cambaleante lhe rememora sua essência de pedra. Afunda para, em seguida, ascender. O corpo quando descolado do espírito possui outra densidade. Eleva-se (ainda que possa afundar-se em ambivalência).

Há algumas evidências de que os personagens de Terrence Malick andam sobre as águas nesse sentido. O truque cinematográfico mais ordinário atende as vontades do estado de espírito: uma câmera na mão frenética aliada a uma montagem asfixiante costumam traduzir angústia de um personagem; a câmera subjetiva vagarosa com pouca luz em close-up costuma revelar medo. Aqui, embora Malick se utilize de uma série de recursos convencionais da cinematografia, seu interesse não está em acompanhar seus personagens com uma câmera dedicada a mimetizar sentimentos. A suave passada flutua 
da mesma forma para todos os dramas interiores. Quando Capitão Smith desbrava o território desconhecido de $O$ novo mundo, sua apreensão e o suspense sugerido pela construção da trama encontram na tela uma calmaria no movimento pendular da câmera; Neil, em Amor pleno, vai fazer sua inspeção de esgoto em uma comunidade, porém a trivialidade da ação não tira o interesse de Malick em manter este típico traslado do plano que sobe e desce para acompanhar a caminhada do personagem pelos córregos urbanos. O Deus invisível de $A$ árvore da vida, segundo hipótese de Bisson, evidencia-se por esta fluidez da câmera gravitacional.

Todos os movimentos naturais da alma são regidos pelas leis análogas àquelas do pensamento material. A graça é a única exceção de fato. Deve-se sempre esperar que as coisas aconteçam de acordo com a gravidade, exceto pela intervenção do sobrenatural. (BISSON, 2014, p. 70, tradução nossa ${ }^{15}$ )

Esta “intervenção do sobrenatural” em Terence Malick não raro se relaciona com Deus. Ora, contudo, caminha por um inquietante discurso existencialista heideggeriano, ora profere um discurso verbal de acentuação das questões morais. Dada a importância do ser para o diretor, uma leitura meramente teocêntrica dos artifícios de linguagem utilizados por ele, como a câmera gravitacional, não é suficiente para explicar a ação sobrenatural que perturba a força da gravidade para se fazer flutuar. Também não devemos caminhar rumo a uma crítica ao panteísmo, como se tudo que houvesse de elevação espiritual nos filmes se resumisse a Deus. A câmera gravitacional sugerida por Bisson evoca os princípios da imaginação. E, para nós, buscar essa qualidade espiritual do aparato técnico e da linguagem deve ser feito via o devanear, nos municiando da fenomenologia bachelardiana.

Bachelard investiga [a imaginação] a partir de textos (imagens literais /literárias) ou obras de arte (imagens pintadas, gravadas, esculpidas). Substitui o enfoque psicológico-gnosiológico, referente à gênese e à sucessão das etapas do conhecimento, pelo enfoque estético, segundo o qual a imagem é apreendida não como construção subjetiva sensório-intelectual, como representação mental, fantasmática, mas como

\footnotetext{
${ }^{15}$ No original: "Tout les mouvements naturels de l'âme sont régis par des lois analogues à celles de la pesanteur matériele. La grâce seule fait exception. Il faut toujours s'attendre à ce que lês choses se passent conformément à la pesanteur, sauf intervention du surnaturel”.
} 
acontecimento objetivo, integrante de uma imagética, evento de linguagem. (PESSANHA apud BACHELARD, 1994, s/n $)^{16}$

Tomemos a alegoria do sonho de voo por um momento. Essa epifania onírica de que estamos voando está intimamente ligada à experiência sensível e pessoal. Compartilhamos da ideia geral de um sonho de voo por meio de um imaginário coletivo que permite a imediata relação ao ato de, em sonho, descolar-se da força da gravidade para superá-la. A experiência sensível pode ter diferentes tipos de efeito ao sonhador - há aquele em que o sono REM o distrai e, portanto, o faz esquecer do voo ao despertar; e aquele em cuja intensidade de voo transcende o espaço onírico até invadir como nostalgia a vida acordada.

O sonho de voo, percebe Charles Nodier (NODIER apud BACHELARD, 1990, p. 28), apresenta um risco para o agente imaginador: a racionalização. $\mathrm{O}$ voo onírico pode ser facilmente vitimado pela criação das asas, da imagem de uma ave ou de um homempássaro. "O sonho de voo nunca pode ser um sonho alado" (BACHELARD, 1990, p. 29). Sê-lo, o condenaria à pena de perder as prerrogativas imaginantes ascensionais da altura e da queda - ou seja, da verticalidade.

Malick alça os voos de sua câmera gravitacional utilizando-se do recurso do travelling. Nesta técnica, ele acompanha de perto (ou nem tanto) seus personagens com um movimento que consiste em concatenar o ritmo da caminhada com o do plano. Uma das formas mais clássicas de se perceber o travelling está em sua função chamada overthe-shoulder (o plano recorta o personagem de costas tendo seu ombro no centro da tela). Os travellings de Malick sugerem um certo descompasso no descolamento entre o ritmo do personagem com o do movimento da câmera. É daí que extrai sua intensidade, seu dinamismo vertical. Ora, seu interesse não está em expressar a narratividade da cena, mostrando de onde para onde se dá o traslado do personagem em travelling. Em Amor pleno, ao deslocar-se rumo à vizinhança onde Padre Quintana (Javier Bardem) fará suas visitas eclesiais, o personagem embarca no travelling após o movimento da câmera ter iniciado por sua conta. Seguem-se planos de casas, desabitadas, descascadas. Um vazio ocupa a tela, mas o movimento permanece constante. Quando o riacho corre, a câmera

\footnotetext{
16 Trecho da introdução do tradutor de $O$ direito de sonhar, José Américo Motta Pessanha, para a quarta edição em português do livro de Bachelard.
} 
flutua por sobre ele, por entre as pedras encravadas na correnteza. A câmera encontra Neil (Affleck) observando as águas, mas logo o atravessa, voltando a conceder protagonismo à natureza. "Em seu voo onírico, se voltamos ao chão, uma nova impulsão nos devolve imediatamente a liberdade aérea" (Ibidem). Em $A$ árvore da vida e $O$ novo mundo, sobretudo, a câmera gravita buscando sempre a contemplação abstrata da natureza, feixes de luz, rios, mares e ação dos ventos sobre a vegetação. Ao desbravar o território virginal da América, o plano busca os quadris, os braços de Capitão Smith (Colin Farrell) apalpando e sendo seduzido pelas plantas, pelas águas.

O movimento quase líquido da câmera de Malick, substituída por uma narração linear, não é mais que uma virtude gratuira, mais precisamente por função de nos fazer sentir a absorvecência divina de uma imagem por outra, o raio único de Deus que se refrata por todas as maneiras da experiência da natureza. (BISSON, 2014, p. 77, tradução nossa ${ }^{17}$ )

Não raro, os travellings de Malick vêm acompanhados de uma montagem caleidoscópica, permitindo que se perceba seus personagens e cenários de diversos ângulos. Uma câmera que exerce uma onipresença, uma essência cosmo-teológica, como conclui Bisson. Os movimentos de câmera estão lembrando a todo tempo de que há uma presença na mise-en-scène para além dos adereços materiais e do material humano. Entendemos que esta valoração (que supõe uma verticalização) seja providência do dinamismo do voo (o qual também supõe a queda, ou aterrissagem).

A linguagem, instruída pelas formas, não sabe tornar facilmente pitorescas as imagens dinâmicas da altura. Entretanto, essas imagens são de um poder singular: comandam a dialética do entusiasmo da angústia. (BACHELARD, 1990, p. 14)

$\mathrm{Na}$ perspectiva do instante poético de Bachelard, Patterson reconhecerá em Malick, especificamente em $O$ novo mundo, o ápice do cinema e de sua apoteose, reunindo uma contradição. "É ao mesmo tempo antigo e moderno, o cinema no seu modo mais puro e orgânico, é simples e refinado, feito com muitas das mesmas ferramentas

\footnotetext{
17 No original: "Le mouvement presue liquide de la camera de Malick, qui se substitue à une narration linéaire, n'est pas d'une virtuisité gratuite, Il a précisément pour fonction de nous faire sentir l'arborescence divine d'une image à l'autre, le rayonnement unique de Dieu diffracté à travers toutes lês gouttes d'experiénce de la nature".
} 
disponíveis na infância à forma dos Lumières, Griffith e Murnau. ${ }^{, 18}$ Essa potência do cinema de Malick apresenta atributos importantes para observarmos adiante, sobretudo em como as vias contraditórias nos permitem caminhar na direção de uma categoria da imaginação mediadora da transcendência; e de uma transcendência manifesta por meio de um discurso poético acerca de Deus. "As categorias discursivas da teologia bem como as imagens tradicionais de um sermão ou de uma prece requerem uma teopoética" (WILDER, 1976, p. 2, tradução nossa ${ }^{19}$ ).

18 Artigo de John Patterson publicado em 10 de dezembro de 2009 no The Guardian (http://www.theguardian.com/film/2009/dec/10/the-new-world-terrence-malick). Acesso em 12 jan. 2013.

${ }^{19}$ No original: "The discursive categories of theology as well as the traditional images of sermon and prayer require a theopoetic". 


\section{Sonhos diurnos a caminho de Emaús}

É a descrição do homem do cinema: o autômato espiritual, homem mecânico, manequim experimental, ludião em nós, corpo desconhecido que temos apenas atrás da cabeça, e cuja idade não é a nossa nem a de nossa infância, mas um pouco de tempo em estado puro

Gilles Deleuze sobre Jean-Louis Schefer 
Enquanto peregrinavam deixando Jerusalém, enlutados pela recente morte de Jesus Cristo, eis que dois homens encontram, na estrada para uma aldeia chamada Emaús, o próprio profeta cristão reencarnado. Não o identificam. Conversam. Cegueira de espírito. Lágrimas obnubiladas. Fé pávida. Discípulos néscios e tardos de coração, só reconheceriam-no quando desaparecesse diante deles enquanto ceiavam.

"Não se nos abrasava o coração, quando ele nos falava pelo caminho e nos explicava as Escrituras?", concluía, parvo, Cléofas, um deles.

Eis o fundamento da teopoética: capturar em um contexto de linguagem o sentido da experiência divina. Obviamente, devemos considerar o axioma da crítica estética da religião de Gottfried Benn, denominado por ele como "conformismo" e "relaxamento de estilo"20. Não buscamos tratar aqui da ação religiosa à qual, submetida a discurso proselitsta busca cumprir objetivos de difusão panfletária da fé ou mesmo do impulso missionário de caráter evangelístico. Nossa observação propõe lapidar o conceito que trabalhamos de teopoética de modo que se cumpra um objetivo fenomenológico de pesquisa em busca de reconhecer que há algo nessa investigação para além das questões pontuais acerda de Deus, espirutualidade, religião e divino. Ponderemos a conclusão de Kuschel:

O discurso sobre o Deus transcendente pode sobreviver no espaço da arte sem que Deus deixe de ser Deus e a arte deixe de ser arte e acabe incorrendo em um tom edificante, de piedade leviana e propaganda religiosa. (KUSCHEL, 1999, p. 214)

A teofania relatada acima por Lucano (São Lucas) no livro bíblico que leva seu nome evoca reflexões em dois sentidos: do real (relato narrado) e do ainda-não-ser (transcendente) - este, um conceito extraído da trilogia utópica $O$ princípio da esperança, de Ernst Bloch. Em comum, para a finalidade desta pesquisa, reside o fato de que ambos carregam a força necessária e a contradição fundamental para nos transportar ao seu eixo

\footnotetext{
${ }^{20}$ De, fato, reconhece Kuschel a respeito de Benn, que Deus se mostra um mau princípio estilístico sempre que rebaixado a objeto de uma literatura edificante banal, a um pretexto para conciliações apressadas e para gratuidades. Os conceitos de Kuschel têm como destino a literatura, mas tomaremos a liberdade de usá-los para nos referirmos à arte como um todo, sempre que essa generalização for possível.
} 
principal: o cinema que chamamos de teopoético. Comecemos pelo último.

Para Schefer, o ainda-não-ser surge como a principal propriedade do cinema - ou do conjunto das relações batizadas por ele como cinema-pensamento. $\mathrm{O}$ ainda-não-ser encontra a realidade como ponto de contato, via reinterpretação do real, que leva a uma consciência - na esfera existencialista proposta por Bloch - de uma possibilidade do que pode nunca vir-a-ser. Por que isso nos interessa? Ora, a teopoética releva como princípio o sr - em sua natureza humana, no âmbito do mito, da poesia, da própria religiosidade, da fé (em esperança ou desespero) e mesmo na literatura secular, segundo os estudos de Kuschel. Temas esses que ocupam muitas das preocupações básicas da narrativa. Do real ou do ficcional, certamente do humano, por meio do que chamamos de relato narrado, documenta, elucida, provoca, subverte, transcende, ignora. Aqui jaz o pensamento, desconcertando o visível em uma ruptura da perspectiva sensório-motora, dadas ações e reações imediatas, automáticas, mumificadas.

A imagem cinematográfica, a partir do momento em que assume sua aberração de movimento, opera uma suspensão de mundo, ou afeta o visível com uma perturbação, que, longe de tornar o pensamento visível, como queria Eisenstein, se dirige, ao contrário, àquilo que não se deixa pensar no pensamento, como se fosse àquilo que não se deixa ver na visão. (DELEUZE, 1990, p. 203)

“Quem somos nós? De onde viemos? Para onde vamos? O que nós esperamos? O que nos espera?”, pergunta Bloch, para quem o início só ocorre definitivamente junto com o fim: "E não é duvidoso afirmar que ele seja enigmático" (BLOCH, 2005). A crise proclamada pela utopia blochiana se fundamenta na inferência de que talvez nunca se dará conta de satisfazer, por exemplo, os anseios que deságuam no "impoder do pensamento" (DELEUZE, 1990). Esse impoder se responsabiliza pelo pensamento morto, inerte, condenado ao nada, que é justamente onde encontra sua potência. O pensamento se declara impotente de pensar, restando a ele promover vibrações. No sentido da experiência da imagem do cinema, as vibrações do fotograma, a provocação da imagem ao espectador que vai gerar, ao final, uma atitude pensante. 
O combate heurístico pelo qual em nome de Deus se evoca o Diabo ${ }^{21}$ conduz-nos a avançarmos nesta reflexão (ou "proflexão", como prefere Bloch): é preciso caminhar pela via da contradição. Não podemos limitar esse devaneio ao campo do cinema enquanto imagem-movimento. Ou seja, no recipiente para o qual - por questões de organização hermenêutica - Deleuze relega o cinema de convenções, de massa, ou o figurativo comercial hollywoodiano - da produção fascista, como incisivamente aponta o crítico Serge Daney. Afora juízo de valor e debate sobre o que é ou não é esse tal cinema da imagem-movimento (se bom ou ruim, não havemos de discutir), a questão mais profunda para a compreensão do pensamento do ainda-não-ser reside na esfera da essência $^{22}$ do filme, do qual é promessa não cumprida e expectativa não frustrada.

Refaçamos os passos dos discípulos cristãos no caminho para Emaús - o nãolugar, indecifrável na atualidade. Não tendo compartilhado a contemporaneidade de Cristo, o evangelista-narrador propõe um deslocamento espacial em um plano espiritual no relato - seja lido como parábola ou como um discurso histórico (no âmbito da crença). O leitor não precisa decifrar o enigma. Cabe a ele apenas sublimá-lo. Afinal, quando o irreconhecível Cristo encontra com os discípulos, sabemos se tratar do Cristo. Não sobram surpresas para o desfecho. O que importa, contudo, é a ausência presente na caminhada (eles o desconheciam) e a presença manifesta na repentina ausência, no desaparecimento (eles, enfim, o reconheciam).

A teofania desta vez ajuda a ilustrar o narrador cinematográfico de Terrence Malick, cuja crise alçada por sua câmera gravitacional evoca um plano espiritual que reside na imagem, mas tem por finalidade o impoder do pensamento, as frequências sensório-motoras da imagem-movimento que buscam a todo tempo momentos de ruptura e arrebatamento. A chama suave de $A$ árvore da vida, neste caso, surge como um elemento importante para exemplificar esta experiência no cinema de Terrence Malick. Fade in e fade out na chama demarcam o início e o fim do filme. A chama surge também para estabelecer fronteira entre os capítulos. Quando a chama se apaga, há sempre algo a

${ }^{21}$ A alogia do mito de Gilbert Durand vai aprofundar esta questão, que aqui só nos interessa a ideia da relação contraditória de se "evocar o Diabo em nome de Deus"

${ }^{22}$ Aqui buscamos tomar emprestado o sentido heideggeriano, do origináio não por uma ótica histórica ou geográfica, mas poético-onto-fenomenológico: poiese (essência) como o agir com sentido. 
se originar. Primeiro, a família O’Brien; tão logo o universo em si; após isso o flashfoward até a idade adulta do filho mais velho dos O'Brien. Ao final, quando a chama revela sua luminosidade e em instantes a esconde, a sugestão é de que o ciclo da vida continua - neste mundo ou não, no passado ou no futuro, conosco ou sem nós.

Visual, visualmente, vista, olho

Visual, visualmente, vista, olho

Visual, visualmente, vista, olho

Visual, visualmente, vista, olho

Visual, visualmente, vista, olho

Visual, visualmente, vista, olho

Visual, visualmente, vista, olho (...) $)^{23}$

A ausência presente surge como a figura central da ruptura "sensório-motora" em Malick, seu modo problemático de apresentar personagens, dramas, hipérboles, elipses etc. O narrador de Malick é como a chama que se apresenta mas prefere ocultar-se. Afinal, por mais que o diretor recorra aos filósofos ao discurso edificante de seus personagens-profetas (os soldados cristãos, os padres, as figuras masculinas arquetípicas do Bible Belt norte-americano), Malick "pensa em imagens. Ele pensa cinematograficamente a mesma coisa que a filosofia pensa em conceitos" (BISSON, 2014, p. 86, tradução nossa ${ }^{24}$ ). Não é mais que um pensamento, é uma questão do ser.

O paradoxo da presença ausente é reproduzido virtualmente em qualquer representação cinematográfica; as imagens na tela forçam o espectador a reconhecer a existência individual dos objetos e indivíduos, enquanto reconhece sua própria ausência. $\mathrm{O}$ cinema produz imagens reflexivas. (FURSTENAU e MACAVOY, 2007, p. 181)

\footnotetext{
23 Arriscamos representar o verso da "teórica do cinema puro", Germaine Dulac. "Todo problema do cinema está nesta palavra 'visualização'... Repito a todo instante tais palavras 'visual, visualmente, vista, olho'... Ora, um verdadeiro filme não se deve contar, já que ele deve tirar seu princípio ativo e emotivo nas imagens feitas unicamente de vibrações visuais". Ver em AUMONT, Jacques e MARIE, Michel. Dicionário teórico e crítico de cinema. Campinas: Papirus Editora, 2003, p. 88.

${ }^{24}$ No original: "Il pense en images. Il pense cinématographiquement la même chose que la philosophie pense en concepts".
} 
Ora, um pensamento deslocado em tempo e no espaço, que problematiza os maneirismos da estilisticamente condenável voz over. Quando Private Witt, em Além da linha vermelha (1998), se pronuncia, sua voz está descolada do momento em que o personagem é visto na tela, conforme já apuramos no capítulo anterior. Àquele momento, ele poderia estar morto - como estaria -, sobrando como presença apenas sua memória póstuma incorpórea, mesmo diante de sua ação reflexiva "real". "Todo mundo procurando salvação para si. Cada um como carvão lançado ao fogo", diz Witt.

Em Terra de ninguém (1973), essa elaboração teopoética ocorre por meio da construção dos personagens. No título original, "terras más", advém uma idealização de purgatório - ou mesmo de inferno, dada a falta de uma reconciliação final. O próprio personagem de Kip (Martin Sheen), embora um delinquente, ora assume características messiânicas, ora faz o papel do ladrão na cruz - ele é o jovem transviado de Elia Kazan, arquétipo de James Dean, sem o aspecto transcendente, e ainda carregado de uma culpa católica e moral religiosa. Ao eliminar a figura paterna de Warren Oats, e diante da frigidez de Holly (Sissy Spacek), a filha, o romance dos jovens se desenrola marcado muito menos pela intrepidez à Bonnie \& Clyde e mais pela relação discipular gerada entre eles. Holly busca a liberdade por meio de seu messias particular, tão logo sua justificação - arquétipo protestante do pensamento. No sentido compreendido por Kuschel ao analisar a obra de Hermann Hesse, tal justificação pressupõe a descrição das rupturas, abismos e contradições da experiência humana. A questão do ser no filme já apresenta características que serão amplificadas ao longo da obra de Malick, desaguando em estilismo e, portanto, em um discurso sobre Deus.

Malick encontrou uma forma de transpor tais pensamentos para nossa meditação e transformá-los em termos cinematográficos com a descoberta de um fundamental aspecto de base fotográfica: os objetos participam na presença fotográfica deles mesmos; participam na re-criação deles no filme. (CAVELL, 1979, p. 32)

Embora evoque um caráter místico e profético, Kip é, para Malick, um ser imanente. A voz de Deus se professa pelos lábios de Holly - o feminino é, por excelência, o narrador de Malick, afora Além da linha vermelha (1998), como veremos mais tarde. As falas de Holly subvertem tempo e espaço mais uma vez. Rybin, em seu estudo 
filosófico sobre a obra de Malick, reconhece que o intervalo entre a realidade visível e a expressa vocalmente gera ambiguidade temática, em vez de certeza epistemológica. A luta interior (no sentido existencialista heideggeriano) dos personagens mantém sempre um enigma de significâncias. Com efeito, Malick lança a voz da personagem para um plano superior, onde não se diz respeito à ação do perímetro da tela, mas se constitui no aquém da imagem deleuziano: "Um pensamento, sem corpo e sem imagem" (DELEUZE, 1990). A título de exemplo, destacamos um dos momentos de virada na narração de Holly, em Terra de ninguém: "Eu até parei de prestar atenção nele. Em vez disso, sentei no carro, li um mapa e pronunciei frases inteiras com minha língua no céu da boca, onde ninguém poderia lê-las."

As aflições do Malick enquanto autor são lançadas na tela como um "aquém das palavras", para utilizar expressão cunhada por Silviano Santiago, para quem a ficção contemporânea existe para tratar da "incomunicabilidade de experiências".

A incomunicabilidade, no entanto, se recobre pelo tecido de uma relação, relação esta que se define pelo olhar. Uma ponte, feita de palavras, envolve a experiência muda do olhar e torna possível a narrativa. (SANTIAGO, 1989, p. 50)

Ao alcançarmos esta esfera - não a da narrativa, mas a do complexo processo que leva até ela - podemos evocar um reavivamento utópico, capaz de se manifestar pelo que Bloch chama de "sonhos diurnos", existentes no limite da concretização da possibilidade do ainda-não-ser. Um devaneio acerca desses sonhos diurnos alimenta, com efeito, a diegese verticalizante do diretor. Os sonhos diurnos de Malick operam no subtexto de sua narrativa, habitam a polivalência da natureza e da existência humana e contribuem para a fruição de sua latência ${ }^{25}$. Esse universo onírico revestido de realidade, se descola da própria noção temporal da narrativa para realizar suas incursões diegéticas, resistindo à tentação do surrealismo, da arbitrariedade do sonho.

Nos sonhos unem-se pela primeira vez o que será decisivo para a constituição da consciência antecipadora; a consciência da fome, e o possível

\footnotetext{
25 Segundo Frederic Jameson, em Marxismo e forma: teorias dialéticas da literatura no séc XX (São Paulo, 1985, PP. 117, 118), Bloch trata de duas perspectivas ao abordar a realização utópica: tendência (possibilidades dinâmicas do desenvolvimento histórico) e latência (potencialidade estética do objeto).
} 
imaginário; os desejos e as imagens. (FURTER, 1974, p. 83)

A especificidade do cinema, segundo Deleuze, é esta: "Vibração como nascimento oculto do pensamento; isso pode parecer e aparentar-se com a mecânica de um sonho sem ser um sonho; é o trabalho puro do pensamento" (DELEUZE, 1990, p. 75).

\title{
2.1 Orvalho espiritual e dilúvio interior
}

\author{
O rio que fazia uma volta \\ atrás de nossa casa \\ era a imagem de um vidro mole... \\ Passou um homem e disse: \\ Essa volta que o rio faz \\ Se chama enseada... \\ Não era mais a imagem de uma cobra de vidro \\ Que fazia uma volta atrás da casa. \\ Era uma enseada. \\ Acho que o nome empobreceu a imagem
}

Manoel de Barros

Há na gênese da formação do mundo - por teorias científicas, fé, sonho ou ficção - um apego pela natureza e um fetiche do caos. O estilismo máximo de Terrence Malick passa sem exceções - por enquanto - pelas propriedades do universo natural. Elas não seguem, em seu cinema, o curso linear de uma enseada, mas deságuam em mar aberto. A natureza não apenas corresponde ao chamamento do poeta, senão ela própria o seduz. Inverte-se a lógica. Em O novo mundo, a trama romântica entre Pocahontas e John Smith nasce como enredo, mas se dissolve com o palco da ação (a relva, o rio, o vento, o fogo). Essa natureza dinâmica, captada pela câmera do diretor de fotografia Emmanuel Lubezki, passa a protagonizar os enquadramentos - nos debruçaremos sobre essas questões específicas do plano cinematográfico no capítulo seguinte. Smith e Pocahontas coadjuvam.

Apropriamo-nos da questão deleuziana acerca da semiologia do cinemalinguagem para problematizar a percepção da imagem natural em Malick. Em vez de perguntarmos "em que condições o cinema deve ser considerado uma linguagem?", 
buscaremos responder de que forma a captura da imagem da natureza no cinema de Malick desemboca em uma linguagem particular - ou, para não contrariar Deleuze ${ }^{26}$, um sotaque próprio. Partimos, pois, do axioma da enunciação tratado pelo filósofo francês acerca da bipolaridade da imagem-percepção (dicissigno, o enquadramento enquanto estado sólido da percepção; e reuma, percepção da fluidez através do quadro), porém, aceitando a articulação pasoliniana de "cinemema" (equivalente cinematográfico do fonema na linguística), e seu poder criador de verbetes imagéticos. A montagem, diria Deleuze, constituiria o epicentro da percepção - ou de seu conceito maior de imagemmovimento, ao qual a imagem-percepção está ancorada. Porém, sua afirmação acerca do tempo no cinema encontra uma tensão para o princípio poético (imagem-tempo) ao qual gostaríamos de legar a linguística fotográfica de Malick, buscando a compreensão do instante poético de Bachelard, segundo o qual, deve-se romper com sua horizontalidade, conforme, entre outros, o princípio de que deve-se habituar a não referir seu próprio tempo ao tempo da vida (BACHELARD, 1994, p. 184). Tomemos Malick como este realizador a assumir toda a complexidade da problemática semiótica de Deleuze e a alcançar o arrebatamento de Bachelard. Certamente, seu cinema congrega elementos suficientes para jusificarem ao menos a presente expedição. "A imagem não é certo significado expresso pelo diretor, mas um mundo inteiro refletido como que numa gota d'água" (TARKOVSKI, 1985, p. 116).

Propomos nos aventurar por esta classificação de um dialeto da imagem de Malick a partir de dois simbolismos bíblicos, ambos remetendo a um dos elementos básicos da natureza mais explorados nos filmes do cineasta norte-americano: a água. Ainda não vamos tratar da água láctea dos devaneios bachelardianos (seu lugar está reservado mais adiante). Para fins metafóricos, discorramos sobre a água em dois estados, que não correspondem precisamente aos das leis da física, mas antes apresentam o desejado potencial teopoético: orvalho (dicissigno) e dilúvio (reuma). Comecemos pelo primeiro. Ora, o orvalho possui duas funções claras na narrativa bíblica: a histórica (sabese que as terras secas da Palestina viveram a glória de 200 dias ininterruptos alimentadas pelo orvalho que formava-se na madrugada) e a providencial (as geadas das primeiras

26 Segundo Deleuze, a imagem não pode ser linguagem por "não ser um material linguisticamente formado, embora o seja semioticamente" (DELEUZE, 1990, p. 47). 
horas da manhã geravam o maná, alimento sagrado enviado por Deus ao povo israelita, durante o êxodo em fuga do jugo do faraó egípcio). Seu valor autotranscendente abastece também a poesia de hinos tradicionais protestantes, para trazermos um contato primeiro com a arte contemporânea.

A gota de orvalho, $o$ fruto e a flor Proclamam constantes o seu grande autor ${ }^{27}$

O cessar da formação do orvalho oferece outro significado importante. A seca, diz o comentarista da Bíblia - Tradução ecumênica, é um dos castigos com que Deus fere seu povo infiel. $O$ pecado do homem repercute em toda a criação e esteriliza toda a atividade humana. "Acima de vós os céus retiveram o orvalho, a terra reteve seu fruto" (BÍBLIA, Ageu 1:10). O díptico culpa humana/castigo divino permeia, com efeito, toda a extensão da obra de Malick. Circunscreve-se refletido nesta gota extraída das escamas da brisa celestial - a imagem enquanto presença, no seu estado sólido da percepção, porém, esculpida por reflexos de uma poética em formação. Vale, neste momento, pontuar, algumas dessas inflexões em Malick com pontos de contato em todos os seis longasmetragens até então realizados pelo cineasta. Por uma opção hermenêutica razoável, repassaremos filme a filme em ordem cronológica de realização, separando-os em três momentos. O primeiro, orvalhoso, que compreende os dois primeiros longas-metragens (Terra de ninguém e Dias de paraíso). O último, da radicalização diluvial, transborda pela tela de $O$ novo mundo, A árvore da vida e Amor pleno. No ínterim, unindo as duas fases de Malick, repousa Além da linha vermelha, a confluência do encontro das águas. Essa escolha nos permitirá observar a evolução da linguagem estilístico-imagética de Malick.

Em Terra de ninguém e em Dias de paraíso, nos quais a narrativa do diretor apresenta ainda um eixo ordenado, sensório-motor, no sentido deleuziano da imagemmovimento, a terra, a água e o fogo desempenham papéis centrais como se fornecessem pistas para um encontro espiritual - não religioso, pois ausenta-se o discurso proselitista do espectador com a jornada de seus personagens. Em ambos os filmes, há um amor

\footnotetext{
${ }^{27}$ Estrofe escrita por David William Hodges em 1989 para o hino cristão Oh, vinde adorar, composto originalmente por Henry Maxwell Wright e William Knapp.
} 
bandido que, para se redimir ou se legitimar, deve empreender um êxodo e uma fuga por assassinato (dois dos célebres feitios de Moisés no Velho Testamento). Há, nesse imbricamento, a tensão entre destino/vontade divina e a culpa carregada desde ou até o Éden de cada um deles.

Também própria aos dois filmes há a condenação, representada pelo fogo. Não a sarça ardente (que não queima) da aparição de Deus a Moisés, mas sim o fogo consumidor, infernal, poético e profético de Sodoma e Gomorra. Kit, quando ateia fogo na casa do pai de Holly em Terra de ninguém, sela sua predestinação no início da jornada - ao som de um canto sacro, a chama destrói memórias e afetividades. Bill, no literalmente crepuscular Dias de paraíso (filmado em pequenos espaços de tempo por vários dias para capturar a luz natural do momento que precede o poente), tem a visão de seu próprio fim na queimada dos campos de trigo da fazenda do "cunhado". Os céus se transmutam do dourado das ruas da Jerusalém celeste para as nuvens pintadas de fumaça. Kit e Holly fazem da floresta seu refúgio no meio do caminho para as montanhas de Montana - as sugestivas "terras más" do título. Há um riacho próximo onde Kit tenta pegar algum peixe. Para ele, apenas uma enseada, como se fosse tão íntimo da natureza a ponto de ignorá-la em sua essência poética. Para Holly, entretanto, pisar na terra crua, sem os pavimentos do urbanismo a que se acostumara a andar na cidadezinha de Fort Dupree em South Dakota, reveste-se "de um significado filosófico de desalienação" (RYBIN, 2003, p. 42, tradução nossa ${ }^{28}$ ), quando finalmente consegue tocar os pés no chão.

Efeito semelhante é desempenhado por Linda, a narradora de Dias de paraíso, ao tocar seu ouvido na superfície terrestre para escutar o coração da Terra pulsar, senti-la guiando-a à sua Canaã. Porém, como fizera Deus a Moisés, fora-lhe permitido apalpar a terra prometida apenas com os olhos. Em ambos os casos, os elementos proféticos metaforizados por Malick aparentam ser apenas mecanismos para alcançar o sublime, para transcender o subtexto do roteiro.

Além da linha vermelha (1998), a reconciliação de Malick com a prática cinematográfica após hiato de vinte anos, agrega novos elementos à estética peculiar do

${ }^{28}$ No original: "a philosophical meaning of disalienation". 
diretor, à qual chamamos de confluência. Seu interesse pela filosofia existencialista de Martin Heidegger - de quem fora tradutor - não só permanece como é irrigada volumosamente por uma trama que sacramenta o rompimento do cinema de Malick dentro do saber deleuziano da imagem-movimento para a imagem-tempo. Ou, se recorrermos a Bachelard, onde a meta claramente se torna a verticalidade. O sereno espelho do orvalho não dá mais conta da poesia de Malick e forma, acima do firmamento, uma vindoura tempestade. Na cena de abertura do filme, um crocodilo submerge, realça a sujeira e os detritos pantanosos na superfície da água. Pela primeira vez, a água encobre totalmente o ser (o crocodilo, no início, os meninos nativos de Guadalcanal em seguida, nas praias paradisíacas do campo de batalha, de onde Private Witt elabora suas crises existenciais e também mergulha).

Assim chegamos ao dilúvio. O proclamador do caos, do apocalipse precoce. A inundação derivada da maior de todas as tempestadades ilustra a segunda fase de Malick, após Além da linha vermelha. A água recobre completamente a tela de poesia que vibra com e pela natureza. "Subitamente, toda a achatada horizontalidade se apaga. O tempo não corre mais. Jorra" (BACHELARD, 1994, p. 185).

James Morrison notará que natureza e beleza em O novo mundo levará a um nível mais profundo a poética da renovação do relacionamento entre homem e meio-ambiente.

Natureza, uma vez que toma seu lugar nessa estrutura radicalmente recortada, só pode aparecer como uma imagem da transcendência falida, sugerindo a possibilidade de uma autêntica imanência com uma carga emocional incomparável aos trabalhos anteriores do diretor. (MORRISON apud PATTERSON, 2007, p. 200, tradução nossa ${ }^{29}$ )

Ao tempo em que Morrison reforçará o sentido imanente da natureza em $O$ novo mundo, as relações simbólicas tanto do Capitão Smith como de Pocahontas com a natureza propõem uma nova leitura sobre o ser. "Ser é transcender", diria Heidegger ${ }^{30}$. A interação de Smith com a mata, o mar e a própria nativa é possível somente pela fé de

\footnotetext{
${ }^{29}$ No original: "Nature, once it takes its place in this radically sundered structure, can appear only as an image of failed transcendence, even if the film suggests the possibility of an authentic immanence with an ardency inmatched in this director's work".

30 Para uma discussão mais aprofundada sobre a influência da filosofia de Martin Heidegger no cinema de Terrence Malick, ver MORRISON e SCHUR, 2003, p. 97-101.
} 
Pocahontas ao invocar a Mãe Terra, a quem dirige suas preces em voz over - a técnica recorrente transmutada em estilo para fins de elevação. A natureza controla o estado de espírito da trama radicalmente elíptica - e até então mais silenciosa (de palavras). Por outro lado, é onde o som se faz onipresente. O nítido bonançar da água, o deitar da chuva, o assobiar da ventania... recobre-se tiros, diálogos e compõe-se uma sinfonia orgânica, potencializada pela fotografia de Emmanuel Lubezki, com quem Malick desenvolverá uma nova abordagem visual pelos próximos dois filmes, consolidando a fluidez da poesia visual. Lubezki potencializa a câmera gravitacional e a testa em incessantes momentos de contraluz.

A árvore da vida sofistica a proposta audiovisual transcendente de Malick, pontuando um universo de cinememas, a saber: voz over como voz do Deus interior dos personagens; crises existenciais elevadas à esfera espiritual; tensões interpessoais em que as interjeições são confrontadas pelo silêncio, pela imagem paciente; o caminho da graça em contraposição ao caminho da natureza; a aproximação de Deus e a negação do divino. Eis o dilúvio interior. O jorro do discurso sobre Deus (da teopoética). A família O’Brien carrega em seu âmago - atravessando a árvore genealógica (tempo/espaço) - o tumulto da catástrofe interior. O colapso iminente encontra guarida também na problemática da fé, como na prece de Padre Quintana, uma variação da Lórica de Proteção de São Patrício em Amor pleno: "Cristo comigo, Cristo antes de mim, Cristo atrás de mim, Cristo sobre mim..."). A crise da desesperança, do silêncio de Deus, tem uma ilustração mais poderosa na figura do pastor luterano Tomas Ericsson, de Ingmar Bergman (Luz de inverno, 1963). Diante do colapso nuclear que aliena o fiel Jonas Persson, o líder religioso, pávido, descrente, impotente, recolhe-se em agonia. Omisso, remoerá o suicídio de sua ovelha caída.

A crise de fé também é central na alegoria de Tarkovski em O sacrifício, 1986. Essa relação do desmoronamento, da ruína interior se transmuta por meio de uma alegoria da solidão, da reclusão, da insensatez, da insanidade. Sobre esta última obra, duas pesquisas apresentam leituras elucidadoras para a conclusão do aspecto transcendente do que chamados de dilúvio interior:

A concepção apocalíptica de Tarkovski está fortemente relacionada ao livro bíblico de João de 
Patmos, em que a destruição do velho e imperfeito mundo deverá levar ao renascimento. O mesmo paradoxo é válido para o sacrifício: a renúncia não significa perda, mas a conquista de um valor transcendente. (VASCONCELOS, 2014, p. 55)

Em Santos, a proposta da crise busca elucidar a problemática da percepção, ao inserir o valor do "tornar a ver", no horizonte teopoético de seu estudo sobre o canto do cisne de Tarkovski:

É no sentido simbólico-teológico, eucarístico, porque o objeto recebido em revelação irrompe e deixa-se transparecer no olhar do próprio espectador que, sujeito deste olhar, o exerce numa atitude de gratidão e comunhão consigo mesmo e com o mundo. (SANTOS, 2006, p. 207)

\subsection{O dogma da extinção (paraíso perdido)}

Das ilustrações bíblicas, o relato do Gênesis, a formação do mundo e, consequentemente, do homem e da mulher, permanece um dos mais reveladores acerca da ideia de paraíso. Adão e Eva reúnem em sua gênese a poética do barro, do vaso perfeito que fora moldado por seu oleiro em condição de matéria mole e transformandose pelo fogo para assumir sua vontade de dureza. A virginal natureza subjugada pela ação do homem caído, a tentação, o pecado, a asexualidade e violência compõem os elementos centrais da derrocada da condição do ser humano de guardião da vida imanente, arauto do reino vindouro do além. Com sua imbuída capacidade transformadora, o ser-homem imita a Deus, portanto, deixa de exercer a função de criatura para ser ele próprio agente criador. Ocupam uma centralidade na vida material. São ceramistas.

Quando um operário vence uma matéria, é capaz de transformá-la, é a natureza inteira que é vencida e é a humanidade inteira que é vencedora na batalha de um dia. Então, uma meditação da oficina amplia-se até chegar a uma meditação do universo (BACHELARD, 2001, p. 49)

Trataremos mais profundamente da relação laborosa do oleiro com a argila no capítulo seguinte. Aqui, partimos da ordem vocacional da humanidade para seu papel de 
construir. Com a emersão da força criadora, contudo, acompanha o poder de destruição. É preciso enterrar o fruto para obter a árvore, matar o boi para comer sua carne, ferir o outro para manter o ego. Este seria o preceito do que intitulamos "o dogma da extinção". $\mathrm{O}$ ato de destruir quando fundamentalmente se relaciona a uma perspectiva de fruição espiritual, tornando-se ritualístico, uma vez que essa extinção, esse desaparecimento, pressupõe um objetivo final a ser alcançado, um arrebatamento, um nirvana.

Bachelard notará ao analisar a obra de Marc Chagall que os caminhos do universo - e do homem - conduzem ao céu. "O universo todo - animais, homens e coisas - tem um destino de elevação (...) o universo tem, para além de todas as misérias, um detino de felicidade. O homem deve reencontrar o paraíso" (BACHELARD, 1994, p. 19). Chagall, nas pinturas analisadas por Bachelard, ilustra as visões do décimo profeta menor velhotestamentário, Zacarias, acerca da escatologia da luz universal. "E acontecerá naquele dia, que não haverá preciosa luz, nem espessa escuridão. Mas será um dia conhecido do Senhor; nem dia nem noite será; mas acontecerá que ao cair da tarde haverá luz." (BÍBLIA, Zacarias 14:6,7). Otimismo da beleza e da alegria em Chagall encontra certa correspondência nos filmes de Terrence Malick. Beleza transcende a história ${ }^{31}$. Ao remontar a lenda de Pocahontas em O novo mundo, a questão central da narrativa escrita (ou reescrita) pelo direitor se concentra mais em simbolismos e em uma elaboração estética da relação entre o ativismo da montagem e uma detalhada elaboração de paisagens. Auele clássico embate entre a colonização e a resistência nativa; o choque de culturas; o romance proibido; a mistura das raças... tudo trafega ao decorrer do filme, mas não o define. Esse encantamento reivindica o protagonismo a todo o tempo. Mais uma vez a voz over desempenha seu papel típico do cinema de Malick permitindo dizer visualmente algo independentemente do que se é dito. Poderíamos reconhecer algo semelhante ao que Bachelard viu em Chagall: "Desenha bem demais para ser pessimista. Confia em seu lápis, confia em seu pincel, logo o mundo é belo $O$ universo é digno de ser pintado faz bom tempo. Sentimo-nos bem num mundo que é belo" (BACHELARD, 1994, p. 21). Malick opera sua câmera com um virtuosismo notável. Arriscando aqui uma aliteração: o universo é digno de ser filmado.

31 TAUBIN, 2006, p. 45, tradução nossa. 
Ao reconstituir a Segunda Guerra Mundial, com Além da linha vermelha, Malick também propõe um olhar que passa por cima do horror do campo de batalha - que fora até criticado à época como "ingênuo" ou "fantástico". Há uma beleza que transcende a violência $^{32}$. Não há um prólogo que nos permite compreender de imediato por que alguns dos soldados - que provavelmente desertaram - estariam convivendo com os nativos. Há um medo por parte das crianças da ilha de Guadalcanal do "diabo branco". Afinal, eles desembarcaram com suas armaduras camufladas e um aparato bélico intimidador. Por outro lado, embora Private Witt (Jim Caviezel) perambule pela tribo à beira da praia vestindo apenas um short cáqui, ainda de peito aberto sua imagem de homem branco impõe medo ali - o desconhecido e o não-familiar permitem essa reação. Nos compassos no ínterim do campo de batalha em si, Malick também recorre à contemplação da natureza, à celebração da beleza: Witt, em momento de descanso próximo a um riacho, enche seu cantil de água e escorre por sobre uma planta. A cena não integra a forma narrativa clássica, do princípio da causalidade ${ }^{33}$. Esse gesto não nos leva a compreender os próximos atos na sequencialização da trama. Está lá apenas para lembrar da beleza do mundo e da glória e imponência da natureza.

Em Dias de paraíso, Bill (Richard Gere) tem a visão do Éden ao saber que seu novo patrão, o Fazendeiro (Sam Shepard), tem pouco tempo de vida. O plano para ele se tornar o Adão da morada dos bem-aventurados se desenha com a perversa ideia de fazer sua esposa, Abby (Brooke Adams), seduzir o Fazendeiro e casar-se com ele. Tão logo o moribundo senhor de terras morresse, Abby reinaria como Eva na erma mansão entre os campos de trigo. Eis a sina do ser imanente: buscar a todo custo seu galardão eterno na vida terrena. Terra de ninguém apresenta semelhante caminho quando Kit (Martin Sheen) e Holly (Sissy Spacek) fogem da cidadezinha de Fort Dupree e se alojam no meio da natureza. Malick evoca os sentidos mais lúdicos da infância, como se a situação dos foragidos fosse a de fogosos adolescentes brincando de acampar, construindo casa na árvore, tentando pegar peixe no rio, rindo (embora também brigando) e vivendo a intensidade da mocidade.

\footnotetext{
32 Isso não significa que não deve haver beleza na violência. Aqui vamos nos restringir a esse recorte.

33 Princípio desenvolvido por Bordwell acerca da cadeia de ação e reação do sistema formal da narrativa de Hollywood. Para um aprofundamento ver BORDWELL, David; e THOMPSON, Kristin. A arte do cinema: uma introdução. São Paulo: Editora Unicamp, 2014.
} 
Além da perspectiva de enaltecimento do universo, de sua beleza, de sua transcendência, Malick enfatiza o dogma da extinção. Não importa o caminho que for percorrido pelos personagens de Malick, o paraíso terreno é sempre uma conquista efêmera. O lastro de destruição deixado pela falta de sabedoria e pela soberba humanas impõe-se no caminho da graça a ser alcançada. Terrence Malick questiona a própria natureza. No prólogo de Além da linha vermelha, Witt (Caviezel) reflete sobre por que há um embate da natureza contra ela própria, deitado debaixo de uma enorme árvore, sob um feixe de luz solar sobre seu corpo prostrado: "Que guerra é essa no coração da natureza? Por que a natureza se rivaliza consigo? A terra despreza o mar? Existirá um poder vingativo da natureza? Não um poder, mas dois?”.

Para Malick, a destruição/rompimento da natreza é uma expressão do nosso estado caído, de nossa pobreza espiritual. Seus filmes são um lamento por um mundo desprovido de inocência e subsequentemente desunido do mundo físico. Essa é uma visão de mndo pré-cristão, do Velho Testamento - nós não fomos redimidos. Fomos expulsos do Jardim, destituídos da presença de Deus na natureza. Cada filme é uma forma de recontar o Gênesis: um paraíso perdido, uma queda da graça, homem dividido contra si. ${ }^{34}$

Dias de paraiso é exemplar ao tratar dos caminhos da natureza versus a vontade humana. Aqui, a natureza oprime os planos mirabolantes do casal Bill (Gere) e Abby (Adams) com sua persistente fotografia crepuscular. A estratégia para conqusitar o paraíso não tem a bênção divina. Sua busca é um réquiem tanto para $\mathrm{o}$ amor compartilhado pelos amantes como para Bill, que conhece a morte inglória ao recorrer às graças do riacho. As águas o traem. Ao fim, Abby e Linda (Linda Manz), companheira de jornada do casal, separam-se. Ambas fogem para seus destinos. Desenha-se um novo paraíso. Uma nova desesperança. Terra de ninguém apresenta semelhante arco dramático no que se refere a essa experiência do paraíso perdido. Para Kit e Holly, dada as circunstâncias propostas pelo enredo (o acúmulo de mau agouro de Kit ao longo da jornada), o que simboliza a queda do homem da graça divina revela-se como

\footnotetext{
34 Extraído do artigo escrito por John Murphy no site GodSpy em 24 de fevereiro de 2006 por ocasião do lançamento de $O$ novo mundo (http://oldarchive.godspy.com/reviews/Paradise-Lost-The-Films-ofTerrence-Malick-by-John-Murphy.cfm.html).
} 
predestinação. Um motivo notório pelo qual conseguimos fazer essa dedução refere-se à tradição do faroeste ao qual Terrence Malick se dispõe a realizar esteticamente. O herói do meio-oeste americano carrega consigo a marca da morte. Nas terras más não há perdão. Devido ao arquétipo do anti-herói tanto de Bill em Dias de paraíso como de Kit, o debate moral sobre suas ações dignifica a busca de ambos pelo paraíso.

Kit anseia por algo lá fora, além da inércia frenética do dia a dia, manifestada, de acordo com a narração de Holly, na imaginária migração ao oeste de Montana, em deslocados espaços de vôo, e na icônica estrada como a rota de fuga dos sonhos americana, de identidade flúida inchecável pelas autoridades - uma terra mágica além da lei (CAMPBELL apud PATTERSON, 2007, p. 46, tradução nossa ${ }^{35}$ )

Após $O$ novo mundo, o dogma da extinção complexifica-se. Em $A$ árvore da vida e em Amor pleno, Malick permite relacionar a questão do fim com o problema da teodicéia. Que Deus é este que permite que o mal floresça? A experiência do profeta bíblico Jó, que embasa a teologia de $A$ árvore da vida, resume-se ao sofrimento, à perda. Como a família O’Brien, diante da morte de seu caçula, R.L. (Laramie Eppler). A extinção não significa o fim, mas um vazio que pode justificar a busca pelo paraíso. Jack (Hunter McCracken e depois Sean Penn), o O’Brien mais velho, é o único que atravessa o tempo da vida. Deixa de ser criança, torna-se adulto. Quando, enfim, Jack se descola de sua vida imanente para o plano do sonho, vemos que seus pais não envelheceram. As águas traidoras de Dias de paraíso aqui manifestam o desejo da reconciliação. Mas aquele lugar ainda não é o paraíso. Um purgatório? Uma passagem ou transição? Talvez o mistério se reserve apenas aos dinossauros para que o conheça, embora carregassem consigo a sina da extinção.

A inconsistência de Jack como adulto nos dá uma pista. Aquilo não é o céu, mas o lugar onde Jack irá completar sua jornada para encontrar seu eu criança e, especialmente, para se reunir com R.L. É uma visão da futura reconciliação com todo mundo e com tudo. É o fim de todas as coisas, mas Jack pode apenas

\footnotetext{
35 No original: "Kit longs for something out there beyond He frenetic inertia of the everyday, manifsted, acoording to Holly's narration, in the imagined migratory West of Montana, in the temporary, displaced spaces off light, and in the iconic road as the American dreamscape of gluid identity unchecked and unfixed by the authoritie - a magical land beyond the law".
} 
espiar momentaneamente e por meio de um vidro escuro. (LEITHART, 2013, p. 86, tradução nossa ${ }^{36}$ )

Para os múltiplos protagonistas de Amor pleno, o paraíso traduz-se em amor. É o que Neil (Ben Affleck), Marina (Olga Kurylencko), Jane (Rachel McAdams) e Padre Quintana (Javier Bardem) buscam a todo tempo. A fé no amor é uma fé falida, um novo dogma da extinção. A reconciliação aqui também não se faz possível. Há apenas momentos de vislumbre do paraíso inalcansável. Marina se debate entre as promessas de eterno amor e a frustração na falta de atitude de Neil para completar a família que tem com sua filha. Em uma única sequência, Malick passeia pela sala de estar de Neil e Marina. Ela, melancólica, segura a mão de Neil, leva-a até seu rosto e beija. Indiferente, Neil escorre o braço para fora do aconchego da mulher amada. Ela toca um tecladinho quando ele reaparece em cena. Ela sorri, dança para ele, o provoca. Ele a toma nos braços. E se jogam no chão trocando beijos e carícias. E brigam. Quintana, em sua pregação, dominado por um conflito de seu casamento com a igreja, precisa falar de amor. "Amor não é só um preenchimento, é uma beleza. Você sente que seu amor morreu? Ele espera ser transformado em algo maior". A espera, matriz etimológica da esperança, preenche apenas o discurso. Os gestos fracassam. "Só o que vejo é destruição. Fracasso. Ruína", conclui Quintana, antes de benzer a sua ovelha.

\footnotetext{
36 No original: "The inconsistency of Jack as an adult when no one else has aged gives us a clue. This is not heaven, but Jack completing his journey to find his younger self and especially to reunite with R.L. It's a vision of a future reconciliation of everyone and everything, but it is only a glimpse. It's the end of all things glimpsed momentarily and through a glass darkly".
} 
Coreografia da adoração: o gesto teopoético

A teatralidade é o teatro menos o texto, uma espessura de signos e de sensações que se edifica no palco a partir do argumento escrito, é aquela espécie de percepção ecumênica dos artifícios sensuais, gestos, tons, distâncias, substâncias, luzes, que submerge o texto sob a plenitude de sua linguagem exterior

Roland Barthes 
Recorremos ao complexo de Jonas com a finalidade de propor um devaneio sobre a profundidade. Esse conceito, recorrente na psicologia contemporânea e nos manuais de autoajuda, tem uma leitura no pensamento de Bachelard que nos interessa para fins de metodologia. Embora haja um fator fortemente psicologizante - inclusive no ensaio de Bachelard -, aqui propomos partir da formulação das imagens reveladas pelo princípio de Jonas, o profeta bíblico engolido por um peixe. Com efeito, propõe Bachelard, que "um complexo é sempre a articulação de uma ambivalência. Em torno de um complexo, a alegria e a dor estão sempre prontas a trocar seu ardor" (BACHELARD, 1990, p. 174). O Jonas de dentro do ventre do grande peixe sintetiza a sensação do cós de uma caverna ou do subterrâneo do mar. Quando nesta posição de afundamento absoluto, escuridão total e de paredes opressoras (do ventre, da rocha, das águas), impõe-se uma morte inevitável. O ventre é como um sarcófago, de onde não há saída. É a "visão de um abismo antropófago" (BACHELARD, 1990, p. 129). No entanto, o ventre propõe, em sua imagem, uma dialética fundamental: sintetiza o espaço de segurança, conforto, abrigo, energia e felicidade do feto. Há, portanto, dois ventres: aquele de onde saímos e o outro, para o qual voltamos. Infância e morte. "O ventre é para a humanidade um peso terrível; rompe a todo instante o equilíbrio entre a alma e o corpo" (HUGO apud BACHELARD, 1990, p. 129). Neste capítulo, buscamos investigar esse movimento de alma e corpo gerado no ventre. Um retorno ao âmago, à profundidade. Do arquétipo de Jonas, não interessa aqui o devaneio sobre a gula - o processo de se engolir sem mastigar -, mas as imagens que nos permitem o vislumbre da expressão mais primitiva da natureza: o gesto.

Com o gesto, não conseguiremos avançar sem antes recorrer à noção de gestus, cunhada por Brecht. O dramaturgo alemão elevou o gestus à condição de essência do teatro. O gestus seria uma atitude, diferente da teatralidade, embora se desse diretamente por meio desse conteúdo de significações corporais às quais Barthes se refere na epígrafe deste capítulo. Embora para Brecht o gestus configure uma qualidade social e política, Deleuze observará que não lhe são negadas outras possibilidades, uma vez que pode ser bio-vital, metafísico, estético e, por que não, teopoético, como havemos de sugerir.

O que chamamos de gestus é o vínculo ou o enlace das atitudes entre si, a coordenação de umas com as outras, mas isso só na medida em que não depende de 
uma história prévia, de uma intriga preexistente ou de uma imagem-ação. Pelo contrário, o gestus é o desenvolvimento das atitudes nelas próprias. (DELEUZE, 2010, p. 230-231)

Esse enlace surgiria em consequência de uma teatralização, de um efeito dramático. É o que Cassavetes aponta ao resumir que a relação dos personagens ou a construção deles próprios não devem surgir da intriga. Antes, a história nasceria por meio delas, em uma exigência de um "cinema de corpos" (Idem). O resultado final seria o espetáculo, ou uma dramatização que abarca toda a intriga. Neste cinema de corpos, busca-se a cerimônia, o aspecto litúrgico e sensível da experiência fílmica. Trata de um escapismo à mera narratologia, não intenta encontrar-se, mas prioriza o ensaio. Como já observamos, Terra de ninguém e Dias de paraíso, dentre os filmes de Terrence Malick, apresentam elementos que os levam a uma compreensão narrativa. Seus encontros apontam para um ritmo que, a partir de Além da linha vermelha, virá a se consolidar experimentando a linguagem corporal antes de enquandrá-lo em determinada estrutura dramática. Voltamos ao impoder do pensamento, à incomunicabilidade que confere ao corpo um novo sentido, uma "imagem-cristal" (DELEUZE, 2010, p. 228). Vamos nos debruçar sobre esse fenômemo no próximo capítulo, quando trataremos do aspecto imagético da obra de Malick, acerca do que se dá a ver e sobre o que se transforma diante da luz. A cerimônia final à qual o espectador de Malick está submetido passa ainda pela teatralidade que, para Barthes, seria um estado de suspensão ou mesmo de divagação e contradição.

Barthes busca impor o modelo do distanciamento brechtiano. O "teatro múltiplo" de Brecht é aquele que mostra, que cita e repete, é o teatro que recorta os gestos, compõe as figuras, interrompe as narrativas, é $o$ teatro que não visa a exprimir o sentido, mas a transformar o real. É o teatro do gestus. (BIDENT, 2012, p. 64)

Definir um gestus como teopoético requer que voltemos mais uma vez a alguns fundamentos da teopoética para, em seguida, relacioná-los às evidências que coletamos da experiência do cinema de Malick. Primeiramente, voltemos a confrontar a religião. No cinema de Malick, há evidências claras sobre a influência da cultura judaico-cristã (desde as figuras dos padres às citações bíblicas ou à construção dos personagens 
invariavelmente onustos de culpa e aspectos morais). Mas Malick não se posiciona ingenuamente diante dos preceitos eclesiásticos. Há uma dubiedade salutar: a longa sequência da formação do mundo em $A$ árvore da vida recebeu leituras por parte da crítica como uma representação criacionista; teólogos, como Leithart (a quem recorremos algumas vezes), afirma se tratar de uma abordagem evolucionista. Os dinossauros representam o grande objeto de impasse para se definir a que matriz pertence a abordagem de Malick. Afinal, embora os gigantes pré-históricos representem um sinal de evolução na história biológica da Terra, as mais liberais correntes científicas que versam sobre a criação admitem haver um processo evolutivo - incluindo o entendimento de que, antes de sua extinção, os dinossauros deixaram um legado genético antes de sua extinção que perdura até hoje. "As diferenças são de ordem filosófica", disse-nos Ruy Carlos de Camargo Vieira, presidente da Sociedade Criacionista de Brasília, durante visita realizada em junho de 2014 às dependências do instituto. Kuschel irá nos lembrar de que os escritores - tomamos a liberdade de abranger os diretores de cinema, devido à semelhança da finalidade do ofício desempenhado, de se contar histórias por meio de arte e linguagem - refletem a complexidade do mundo moderno em suas obras.

Escritores são habitantes de diversos mundos (...) Há muito tempo esse mundo deixou de estar estruturado de forma monolítica: ele é constituído pela concomitância de coisas contraditórias, pela simultaneidade do que antes parecia pertencer a campos diversos da realidade. Daí resultaram amálgamas espirituais novos e desenvolveram-se novas fusões culturais - especialmente no que diz respeito à religião. (KUSCHEL, 1999, p. 215)

Encontramos com frequência nos filmes de Malick esse impulso original derivado das contradições em ambivalência e que, com efeito, envolvem a melancolia formadora e o assombro do porvir. A começar pela própria câmera gravitacional da qual falamos, ela propõe um gestual próprio dinamizado por sua potências verticais de voo e de queda. A natureza também nunca está passiva. As águas que correm, os ventos que sacodem as folhas das árvores, o fogo que consome, a vida incidental de aves, cães, insetos recortando diálogos ou as imagens da dura narrativa. Assim vamos buscando imaginar como Terrence Malick cria seus isomorfismos. O mise-en-scène de Malick é construído pacientemente, por meio de uma artesania que respeita os caprichos da natureza e reflete 
toda essa harmonia e contradição de ordem espiritual, onde começamos a reconhecer os fenômenos dos instantes de Malick, os polos ambivalentes que quase se tocam (BACHELARD, 1994, p. 187).

John Toll, diretor de fotografia de Além da linha vermelha, dirá na história oral biográfica do cineasta que "por ser um filme de Terrence Malick, muita gente simplesmente já supõe que todo mundo fica sentado esperando a hora mágica" (MAHER JR., 2014, p. 118, tradução nossa). São horas a fio nas locações, com toda a equipe técnica e atores submetidos a uma espera e a um ensaio natural do convívio dos atorespersonagens entre si, como se a própria natureza ou estado de espírito devessem pautar a forma dos acontecimentos quando a câmera for ligada. Jonas está à deriva e espera-se o peixe que irá devorá-lo, para então seguir com a história. O que percebemos é que o interesse de Malick está na qualidade gestual que pretende extrair de seus atores (e de seus diretores de fotografia). O desafio é naturalizá-los. Em Além da linha vermelha, O novo mundo e A árvore da vida, ocasiões em que Malick filmou longas sequências protagonizadas por crianças, Maher Jr. contará que a ordem do diretor era de que a meninada atuasse em loop, interagindo com os adereços de cena, com o solo, com o espaço e entre si sem se importar com o "corte", como relata Jack Fisk, seu designer de produção em todos esses filmes citados e nos dois seguintes (incluindo Cavaleiro de copas, 2016).

Terry, como diretor, está sempre aberto e alerta às coisas que estão ao seu redor. Às vezes ele está filmando, um pássaro interessante voa e ele começa a subir em uma árvore e apontar as câmeras em sua direção. Ou então nós elencamos cachorros para o filme e ele os deixa brincando lá fora e os filma longamente, com as crianças interagindo. Algumas vezes são apenas brincadeiras sobre a grama. Para Terry, é um importante simbolismo da vida. (MAHER JR., 2014, p. 163, tradução nossa ${ }^{37}$ )

Conseguimos, por meio dos relatos e da observação dos filmes de Malick,

\footnotetext{
37 No original: "Terry as a director is always open and aware of the stuff that's around him. Sometimes we'll be shooting a film anda $\mathrm{n}$ interesting bird will fly by and he'll start crawling on a tree and directing the câmeras toward that bird. Or we cast dogs for this film and then He would let the dogs play outside and shoot a loto f footage of them interacting with the kids. Some of it it is just playing in the Grass. For Terry, it's an important symbol of life.
} 
identificar quatro categorias nas quais se adota um sistema gestual que tanto se repete de filme a filme, como teatraliza essa jornada transcendente a que reconhecemos como teopoética. Típicos do cinema do diretor, os momentos de brincadeiras lúdicas. Em todos os filmes, Malick propõe uma infantilização do amor teatralizadada por meio de cenas que não servem a determinado propósito narrativo. São momentos de suavidade ou de distração que cumprem uma função estilística ao remeter à ideia apocalíptica da Nova Jerusalém. "Ele enxugará toda lágrima de seus olhos. Já não haverá morte. Não haverá mais luto, nem clamor, nem sofrimento, pois o mundo antigo desapareceu" (BÍBLIA, Apocalipse 21:4). Em Terra de ninguém, Kit (Sheen) e Holly (Spacek) se desligam do mundo opressor e da culpa irremediável em seus momentos de dança. No acampamento improvisado em meio à mata, eles colocam o rádio de pilha para dançarem (uma leitura também da urbanidade que carregam consigo); em meio à escapada para as terras más de Montana, a aflição da fuga não lhes cerceia uma valsa debaixo da noite que se impõe.

Mas é em Dias de paraíso que Malick inaugurará os momentos de brincadeira. Linda (Linda Manz) faz uma amizade com outra garota em meio aos campos de trigo. Elas se divertem capturando gafanhotos. Logo Bill (Gere) entra no jogo, escapando de Linda, correndo e rindo. Linda e Abby (Adams) correm atrás do pavões. Mais uma vez Malick recorre aos encantos do gesto de dança. Em um momento na floresta, Abby imita as garotas de Baker Hall para o Fazendeiro (Shepard), que a observa sentado em um tronco. Sob uma casinha de madeira em meio ao campo, durante uma refeição, Bill lança pedaços de comida em Linda. Ela sai correndo e ele a persegue dando corda à brincadeira. Além da linha vermelha resumirá esses momentos lúdicos à relação de Private Witt (Caviezel) com as crianças nativas da ilha de Guadalcanal, embora ele muitas vezes apenas as observe, como se ele não pertencesse (ou merecesse) estar ali. Smith (Farrell), em O novo mundo, assume postura semelhante. Ele não brinca, também, de certa forma, lhe é negada a Nova Jerusalém. Ele observa Pocahontas (Kilcher). Acompanhamos por uma câmera gravitacional subjetiva a corrida saltitante da bela índia sobre a relva verde. Deitado sobre o chão, Smith tenta pegar os pés de Pocahontas. Ela se desvia. Anda sobre um tronco deitado e joga folhas sobre Smith. Ele sorri. Apenas John Rolde (Christian Bale), o outro homem branco a se apaixonar por Pocahontas, consegue compartilhar das brincadeiras de Pocahontas. Ao arar a terra para a plantação, ele a 
levanta e a carrega. Em seguida joga seus cabelos para trás, enquanto mastiga um talo da grama. Ao final, Pocahontas se reconecta com a natureza, embora paramentada com um pomposo vestido vitoriano, diverte-se ao se molhar com a água do lago, corre pela grama, rodopia.

Os gestos de inflexão como contração, como ato de estar fora de si mesmo se reproduzem eletrificados pelos jump cuts, que como curtos-circuitos, focam uma lógica intelectual com conexão emocional com uma aura que lembra a infância. A infância como proclamação de pura alegria, representada em gestos infantis, miríades, danças e fogos de artifício explodindo, cujo crepitar sugere uma relação mantida na memória a conflagração original do Big Bang. (CHAKALI, 2014, p. 131, tradução nossa ${ }^{38}$ )

A árvore da vida e Amor pleno terão seus momentos lúdicos esparramados ao longo de toda a projeção, o que também alimenta uma percepção mais clara da insuperável crise espiritual dos personagens. Logo em uma das primeiras cenas, Mrs. O’Brien (Chastain) senta-se no balanço de onde observa os filhos correndo com o cachorro e caindo no chão. Ela corre descendo a rua fugindo dos meninos. Mrs. O'Brien molha os filhos com água da mangueira. Eles revidam e a casa é só sorrisos. A rigor, a Nova Jerusalém está claramente definida como aquela casa dos O'Brien, porém, desde que o pai não esteja por lá. As brincadeiras de Mr. O'Brien (Pitt) tolhem todo o sentimento lúdico e espontâneo. Quando ele ensina os meninos a boxear, não há alegria no semblante deles.

Há muita dança em Amor pleno. Marina (Kurylencko) está sempre bailando, na rua, no supermercado, na mata, dentro do apartamento, na piscina. Neil (Affleck) adota uma postura mais indiferente - a exemplo da maioria das figuras masculinas de Malick, uma forma de desvelar o machismo presente na cultura judaico-cristã. Quando Jane (Rachel McAdams) laça a atenção de Neil, a liturgia do ritmo se repete. Sobre os trilhos, ela corre, desequilibra-se graciosamente, ri para ele. As mulheres provocam Neil. Marina

\footnotetext{
${ }^{38}$ No original: "L'inflexion gestuelle comme contraction de l'être hors de soi est définitivement passée dans le montage électrisé par des jump cuts qui, tels des courts-circuits privilégiant le raccord émotionnel sur la logique intellectuelle, font sautiller d'une strate à l'aure l'enfance rememorée. L'enfance comme exclamation et purê joie d'ek-sister se ventile alors en myriades enfantines de gestes, danses et jeux explosant en feux d'artifices dont le crêpitement aurait gardé en memoire l'embrasement originel du Big Bang".
} 
mesmo, na ausência do aconchego do seu marido dança com um galo no colo e o provoca. Marina, sobretudo, está filmada em panorâmica durante quase toda a projeção. A montagem caleidoscópica de Malick aqui ganha um aspecto ainda mais evidente. No momento em que a filha de Marina, Tatiana (Tatiana Chiline), observa o movimento dos brinquedos aéreos do parque de diversões temos ali um símbolo do epicentro das crises de Amor pleno: uma gangorra de sentimentos e de gestos - ora violentos, ora carinhosos.

Tais brincadeiras vão muitas vezes se confundir com um segundo elemento fundamental para a coreografia do cinema de Malick: as carícias. Ao seu modo rebelde à James Dean, Kit demonstra afeto a Holly em Terra de ninguém. Há uma masculinidade que não lhe permite uma expressão gestual mais delicada - afinal, quando Kit tira a virgindade de Holly, o que se vê é apenas ela a terminar de abotoar o vestido. Kit não dá bolas e ela mesma ainda não entende muito bem os códigos do pós-coito. Também demonstrando a força de homem, Kit coloca-se como protetor de sua amada. Ao serem ameaçados ele toma a dianteira, assume uma postura heróica. Em Dias de paraíso, os omentos de Bill e Abby ganham notas mais dissonantes. Deitados sobre o campo de trigo, ele pinça com os dedos alguns fiapos de sua roupa. Já desposada pelo Fazendeiro, ela encontra Bill no rio, o refúgio dos esposos agora amantes. Ele lava os pés dela. Em um riacho, Bill e Abby levantam a barra de suas vestimentas, chutam a água, beijam-se e abraçam-se. Logo ele tenta levantar sua saia, no que ela, sorrindo, o retribui com tapas gentis. Com o coração de Abby mais inclinado para o Fazendeiro, ela permite ser tocada suavemente pelo novo marido e até se refugia no seu seu novo ninho de amor da fúria de Bill, que o levará de volta ao seu ciclo assassino - no começo do filme, Bill, Abby e Linda fogem de um trabalho na mina devido às consequências das atitudes violentas dele.

Essa tensão entre violência e delicadeza permeará toda a obra de Malick, ressaltando aspectos contraditórios que nos permitem a leitura da verticalidade das transações emocionais no cinema do diretor. A guerra de Além da linha vermelha tem vários momentos de respiro, que não deixam de ser pesarosos. Embora os gestos demonstrem certa paz, o espírito inquieto se revela pela voz over atribulada, ressentida ou desesperançosa. São assim os momentos de Private Bell (Ben Chaplin) com sua esposa Marty (Miranda Otto) nos flashbacks que nos transportam de Guadalcanal para a vida urbana e pacífica de casa. Ele a abraça por trás, toca seus seios. Ele deita em seu colo. Em 
seguida, toca de todas as formas possíveis seu rosto, como que para decorá-lo e carregálo como lembrança. Os movimentos que Bell e Marty protagonizam aqui são como se coreografados em uma quase-dança. Ela beija e a afasta, segurando seus braços, a aproxima de volta fugindo ao naturalismo. Os momentos de Smith e Pocahontas em $O$ novo mundo também são peculiares. Eles se tocam para se conhecer no íntimo, conhecer a história de seus povos. O toque que se permite é das culturas. No entanto, Malick insiste em esperar. O toque torna-se sedutor e logo os lábios começam a se aproximar ainda que não se toquem. Os dedos de Smith correm sobre o braço de Pocahontas até que as mãos se unam. Ele encosta o roso em seu peito. Ela acaricia sua cabeça. "Tudo está perfeito. Deixa que eu me perca. Flua em mim como um rio", diz Pocahontas, em off.

Por força temática, talvez, em Amor pleno Malick consegue explorar o sexo como celebração desse louvor proclamado pelo arcabouço gestual de seus personagens. As brincadeiras dos amantes culminam algumas vezes em atos de preliminar sexual. Em meio à briga do casal Marina (Olga Kurylencko) e Neil (Ben Affleck), no apartamento vazio, eles se inspiram a recuperar o primeiro amor. Ele a sufoca gentilmente com o tecido suave e transparente da cortina. Eles se jogam ao chão. Beijam-se. Neil desliza pelo corpo esguio de Marina coberto por uma camisola azul escuro. Sugere-se um ato de sexo oral. Mas o semblante de Marina não reflete mais prazer. A melancolia volta a dominá-la. Neil não está mais lá. As mãos de Marina esticam o curto vestido para baixo e suas pernas se fecham. O sexo não se consuma. Neil reencontra sua antiga paixão, Jane. Marina permite-se um encontro casual íntimo com um rapaz que encontrou na rua, como ato de vingança. Quando os corpos de Neil e de Marina se tocam novamente, ambos estão em uma piscina pública. Há mais gente ao redor. Neil aproxima-se sorrateiramente por trás de Marina. Susurra em seu ouvido. A câmera de Malick mantém seu compromisso com a suavidade. Os gestos permanecem fluir segundo a coreografia do toque gentil, embora a abordagem de Neil seja violenta. Marina fica evidentemente apavorada. Mas em silêncio. Ela afunda-se, recobre-se das águas para tentar fugir do marido transformado em agressor. Logo ela o abraça por baixo do lençol líquido da piscina. Ele retribui. Recomeçam as brinadeiras quando Neil tenta tirar seu biquíni. Eles sobem à superfície. Corte seco para o bar. Ele a evita. Com rispidez, vira o queixo de Neil para que ele a olhe. Na voz over, ela pergunta: "Você me quer como sua esposa?" E 
voltam as brincadeiras lúdicas, as lembranças triviais superdimensionadas pela coreografia. Neil empurra Marina em um carrinho de supermercado. Entre as estantes, ela o seduz abrindo o casaco. E foge graciosamente dele, evidentemente constrangido, mas com um sorriso. Outro corte, e Marina sai às pressas de casa anunciando ao bairro: "Ele está me matando". Neil a acompanha a seguir. A violência está sempre presente, mas os gestos mantêm a singeleza da coreografia. A violência emudece a música. Ela se humilha perante o macho. Beija seu pé. Começam juntos a limpar a casa. Logo voltam as brigas. Ele a segura com um dos braços. Com o outro arranca a cortina. A sinfonia suave acompanha a reconciliação. As mãos de Marina socorrem a mão ferida de Neil. Ela beija sua mão ensanguentada. Em seus últimos gestos, entre a cortina preta transparente, Marina evoca: "Meu Deus que guerra cruel. Vejo duas mulheres em mim. Uma cheia de amor por ti. A outra me puxa em direção à terra".

No lugar onde as figuras gesticulam volatilmente como a inconsistência de areia recai uma impotência diante do compromisso de romper com o arsenal de indecisão dos personagens, nos quais ainda brilha um gesto simples e infantil (...) A espiritualização da Natureza compartilhada pelas esferas do profano e do sagrado se representa no amor. (CHAKALI, 2014, p. 132 , tradução nossa)

O amor deixa vestígios de três ordens: fileo (fraternal), eros (erótico-carnal) e ágape (divinal). Os dois primeiros transcorrem por um fluxo horizontal - entre iguais (família, amigos, amantes). Por convenção do imaginário coletivo e de uma tradição da religiosidade oriental, o amor-ágape trata de uma relação vertical: o homem, preso à força gravitacional do eixo terrestre, invoca o ser superior, no alto, no além. Quando Bachelard diz que "a meta é a verticalidade" (BACHELARD, 1994, p. 184), conclui que o instante poético possui uma perspectiva metafísica. $\mathrm{O}$ gesto do consolo e da compaixão, nossa terceira categoria, seria essa expressão que se descola da horizontalidade humana para alcançar a verticalidade divina. "Na saudade risonha vivida pelo poeta, parece que realizamos a estranha síntese da saudade e do consolo" (BACHELARD, 1990, p. 110). Afinal, a compaixão pressupõe uma alteridade. Malick costuma expressá-lo por meio de close-ups nas mãos, como em Além da linha vermelha. Vemos a mãe moribunda que estica a mão para a filha; a garota que toca o coração da mãe e abre um sorriso. $\mathrm{O}$ novo 
mundo exibe gestos de solidariedade, quando os indígenas enfim acolhem Capitão Smith $\mathrm{o}$ tocam-lhe no peito, o testam mas o dignificam. Em $A$ árvore da vida temos o compêndio mais completo do uso das mãos. No início, diante da perda de R.L., seu filho, Mrs. O’Brien recebe o toque das mãos de uma idosa do convívio íntimo da família e também de uma mulher negra, que também não identificamos. $\mathrm{O}$ anonimato pode ser uma potência ao se fazer o bem. Ao final, são as mãos de R.L. em seu reencontro com o Jack (Sean Penn) que o aliviam da culpa do passado. Toca-lhe as mãos, os ombros, a cabeça. Jack retribui o toque a um garoto da vizinhança, que fora vítima de um incêndio. E ainda há o gesto muito significante da vida primitiva na Terra. Um dinossauro com sua pata toca a cabeça do outro que estava prostrado sobre as pedras de um riacho e o liberta. "Quando a compaixão evolui, o mundo está pronto para o clímax da criação, uma criatura com mãos" (LEITHART, 2013, p. 59, tradução nossa).

Em Amor pleno, Padre Quintana (Bardem) visita os enfermos, como parte de sua rotina clerical. Toca-os. A senhora moribunda estica a mão e Quintana a segura. De sua voz em off repete a Lórica de Proteção de São Patrício ("Cristo antes de mim, Cristo depois de mim, Cristo em mim, Cristo acima de mim, Cristo à minha direita, Cristo à minha esquerda, Cristo no coração"). Quintana se reconcilia com Deus: "Brilhe através de nós". O pedido de perdão de Neil a Marina se dá também pelo gestual. Não há troca de olhares, embora os olhos de Marina se pareçam surpresos com o gesto de Neil. Ele se ajoelha diante dela, coloca a cabeça em seu colo. Ela o afaga. "Esse amor que nos ama", conclui ela.

Para uma coreografia da adoração ser completa, resta-nos envolver a questão da musicalidade, o que dá liga a toda a coreografia. A Lacrimosa, do Réquiem for a friend, de Zbigniew Preisner, conduz o maior de todos os gestos de Malick: a criação evolutiva do universo. Sem recorrer a quase nenhum recurso tecnológico (à exceção da recriação dos dinossauros e das criaturas marinhas), Malick recria o início da existência terrena com suas mãos. Ou melhor, as mãos de Douglas Trumbull (reconhecido diretor de efeitos especiais de 2001: Uma odisséia no espaço). Utilizando-se de grandes tanques cheios de líquidos, tintas e demais fluidos e ingredientes químicos, Trumbull promoveu o espetáculo da Terra com ajuda da objetiva em alta velocidade de Emmanuel Lubezki em favor de se louvar a artesania proposta pelo Gênesis. "Tudo foi feito por meio dele; e sem 
ele nada se fez do que foi feito" (BÍBLIA, João 1:3).

A concepção musical de Malick se estrutura por criar árias e hinos de características de ua liturgia esclesiástica. O canto gregoriano Passion, de Carl Orff, sonoriza a sequencia do incêndio da casa do pai de Holly em Terra de ninguém. Revela essa primeira potência poética, através do fogo consumidor, lastro inconsequente da paixão ardente dos jovens foragidos: o som sugere uma opulência, enquanto é vista a destruição material de objetos e memórias daquela casa. $O$ fogo terá significado semelhante em Dias de paraíso no momento das queimadas dos campos de trigo para combater a praga de gafanhotos, quando há uma trilha sonora de suspense e ação dialogando com as imagens contemplativas de Malick. No momento em que ele adota uma câmera na mão e reproduz na montagem a correria e a luta dos trabalhadores para conter o fogo a música cessa. Há apenas vento e chama. No mesmo filme, a trilha sonora também ocupa lugar de mediadora da ação humana com a natureza. Mais uma vez acompanha uma cerimônia. Neste caso a música de Ennio Moriconne imprime à montagem uma harmonia na trama e em sua aura. "A alegre trilha de Morricone acompanha a dissolução de uma série de imagens que casam Abby e o Fazendeiro não apenas entre eles mas com os próprios ritmos da natureza" (RYBIN, 2013, p. 82, tradução nossa ${ }^{39}$ ). Power notará que a música de Dias de paraíso providencia “oportunidades metafóricas de expressão". Ele cita especificamente o uso do tema The aquarium, de Camille Saint-Saëns. "Há vários instantes ao longo do filme em que a ideia de um aquário é usada simbolicamente, inclusive quando a música não está sendo executada" (POWER apud PATTERSON, 2007, p. 105, tradução nossa ${ }^{40}$ ). Power se refere à ideia da fazenda, como um paraíso artificial, um ambiente seguro, porém, visto de fora, uma jaula (neste caso, de sentimentos).

Além da linha vermelha incutirá às sinfonias clássicas sacras um dos marcos da postura devocional que a música exerce no cinema de Terrence Malick com o canto da tribo entoado em seu dialeto próprio (tok pisin). A harmonia de louvor preenche os vazios da solidão de Private Witt na ilha. A música apresenta-se na forma de acúsmetro,

\footnotetext{
${ }^{39}$ No original: "Morricone's joyous score acompanies the dissolve to a series of images that marry Abby and the Farmer not only to each other but to the very rhythms of nature"

40 No original: "There are several instances throughout the film when the Idea of an aquarium is used symbolically, even when the piece of music itself is not being played".
} 
abordando a beleza natural do cenário e dos nativos até enxergarmos a formosura da dança e das vozes a capella. O uso da música aqui está intimamente ligada à diegese sonora do complexo fílmico. Como fizera em Dias de paraíso, seu trabalho sonoro mais complexo em significados, Além da linha vermelha apresentará um claro avanço tecnológico, dado o avanço do sistema Dolby, aliando a música a uma colagem de sons de elementos da natureza, criando uma atmosfera psicológica e metafísica ao redor das paisagens e dos personagens.

Não há coreografia sem música no cinema de Malick; até o silêncio na trilha ressoa. A musicalidade completa a coreografia. Nos sons mudos, os gestos ganham novos significados, novas potências e reforçam a envergadura poética de seu discurso imagético. Tarkovski diria que, para o universo poético do filme, a música deve cumprir um papel maior do que a de intensificadora do impacto da cena. Ela deve renovar a imagem, produzir uma inflexão lírica e até providenciar uma distorção ao material visto. "Ao mergulharmos no elemento musical a que o refrão dá vida, retomamos inúmeras vezes as emoções que o filme nos despertou, e, a cada vez, a nossa experiência é aprofundada por novas impressões" (TARKOVSKI, 1990, p. 190).

O próprio cinema está dotado de uma particular natureza rítmica em sua teoria. Como a imagem, os diálogos e a montagem, a música enaltece a ritmicidade da trama, como irá notar Laurent Guido. Para ele, a forma como Malick se utiliza do imaginário da pastoral americana e dos traços culturais da sociedade judaico-cristã anglo-saxônica transformam seu arcabouço de referências sonoras em um sistema de represetação cultural em todos os seus filmes - até O novo mundo, pelo menos.

Evocar seriamente a suposta musicalidade do cinema, mais precisamente a que diz respeito aos elementos visuais, retorna com o objetivo de abordar a noção de ritmo que regula a ordem de movimento. A esse parâmetro é atribuído um papel central no último filme de Malick [O novo mundo]. Em grande parte, a singularidade por si só se origina efetivamente na maneira particular de entoar o fluxo narrativo por um ritmo amplo e constante. Se a sucessão visual parece à primeira vista ter uma certa descontinuidade, se estabelece principalmente por viajar nos planos que delineiam o espaço de digressão (um parênteses na história que está sendo contada), a instalação é de fato 
governada por princípios estilísticos visando imprimir um movimento uniforme, homogêneo ao conjunto das imagens. (GUIDO, 2007 p. 56, tradução nossa ${ }^{41}$ )

O resultado, conforme Guido é uma forma fluida, quase orgânica em que os métodos de corte convencionais com base nos planos de linearização espaço-temporais não são sistematicamente rejeitados (daí o uso frequente de reverse shot em blocos sequenciais facilmente identificáveis...), mas são integrados em uma composição audiovisual cuja lógica discursiva se revela tanto complexa pela multiplicidade de informações e pontos de vista quanto pela unidade subjacente constantemente sugerida pela sucessão harmoniosa dos planos. Guido irá se ater também à herança sempre presente da estética pós-romântica dentro do cinema hollywoodiano, por meio da influência de Wagner sobre os modos de construção do espetáculo de massa. "É necessário assinalar as linhas existentes entre o romantismo alemão e a tradição especificamente americana da qual Terrence Malick faz referência desde o início de sua carreira" (GUIDO, 2007, p. 58, tradução nossa ${ }^{42}$ ).

A música em Malick evoca, portanto, como que uma cerimônia religiosa, uma liturgia com aspectos de adoração. "Venha espírito, cante a história do nosso povo", clama Pocahontas à sua Terra-mãe em um plano contra-plongée no qual ela ergue os braços ao céu azul. Havemos de notar que a volta de Malick constantemente a esse tema, um lugar-comum da prece legada ao firmamento, não busca apenas uma representação, senão apontar uma direção de seu gesto de louvor - um cântico da história de seu próprio povo -, a expressão de uma teopoética, uma vez que assume suas vias de contradição e de elevação.

\footnotetext{
41 No original: "voquer sérieusement la musicalité supposée du cinéma, plus précisément celle qui concernerait les éléments visuels, revient en fin de compte à aborder la notion de rythme qui règle l'ordonnance du mouvement. Ce paramètre se voit attribuer une fonction centrale dans les derniers films de Malick. Pour une large part, la singularité de ceux-ci s'origine effectivement dans leur manière particulière de scander le flux narratif par une rythmique ample et régulière. Si la succession visuelle affiche de prime abord une certaine discontinuité, établie le plus souvent par des plans en travelling qui esquissent l'espace diégétique, le montage y est en effet gouverné par des principes stylistiques visant à imprimer un mouvement homogène à la suite des images".

42 No original: "Il est nécessaire de signaler les liens existant entre le romantisme allemand et une tradition poétique spécifiquement américaine à laquelle Terrence Malick se réfère depuis ses débuts".
} 


\subsection{Liturgia da alma: o ferreiro, o oleiro e a sina laboriosa}

Há uma escatologia que emerge da natureza: não há vida sem morte; cada início procede de um fim; ao pó o homem retornará... O movimento circular biológico resumese a uma criação dotada de força criadora (seja do logos divino, seja do hermafroditismo entomológico) e igualmente de predicados destrutivos. Essa circularidade configura um segundo ato desta compreensão litúrgico-imagética encontrada na realização cinematográfica de Terrence Malick.

\section{Ó natureza, rainha das primícias, Vede quanto trabalho se põe \\ Debaixo de seu sol \\ Desde antes dele, Quando tu eras caos \\ E os sinos da criação \\ Jubilavam pela metaforma vida \\ Teu logos ascende ao firmamento \\ Das profundezas de teus olhos \\ Sibila o réquiem da humanidade}

Com esses livres versos, almejamos aprofundar as reflexões acerca da ritmicidade na obra de Malick para o reino laboral mimetizado pelos conflitos da ordem bachelardiana do dualismo energético (matéria e mão). Buscamos conjugá-los ou friccioná-los diante da sabedoria profética do livro bíblico dos Eclesiastes, discorrendo sobre o labor nas naturezas imanente e transcendente. O trabalho da natureza enquanto primícia do caos, carregada de uma relação com o sagrado (a Terra-mãe, cultuada em $O$ novo mundo; a vocação destrutiva do próprio universo sugerida por Além da linha vermelha; o Deus criador que ronda $A$ árvore da vida) e com o chamamento do homem à sina laboriosa (objeto da revolta de Kit em Terra de ninguém; impulso que descloca Bill até seu purgatório, a fazenda de Dias de paraíso; ou nas inspeções de Neil pairando por córregos e esgotos da cidade). Ambas extremidades - o fazer e o desfazer - importam

ontologicamente para nossa expedição, para a perseguição de uma teopoética. Não faremos esse tensionamento apenas por meio da mera oposição das forças (bem-mal/céuinferno/verticalidade-horizontalidade), mas, sobretudo, por encontrar nessas relações movimento, transformação - ou dinamismo, como prefere Bachelard. 
Pela própria matéria de seu trabalho, na proeza de suas forças, eles (os trabalhadores) têm visões de universo, as visões contemporâneas de uma Criação. O trabalho é - no próprio fundo das substâncias uma Gênese. Recria imaginativamente, mediante as imagens materiais que o animam, a própria matéria que se opõe a seus esforços (BACHELARD, 1991, p. 26)

Ao exercer um golpe sobre a matéria, o construtor propõe, segundo Bachelard, um mais-que-ser da imagem do devir do objeto a ser transformado. Aquela estrutura original colocada em choque por intermédio do poder destruidor da ferramenta a aumentaria para um quê agora formado por uma existência dinâmica. O universo imaginário do reino material, da operacionalidade das mãos humanas diante do exercício criador, compreende imagens sempre colocadas em oposição de forças ou vazios que se complexificam. A partir deste poderoso dualismo energético bachelardiano, entendemos que o esforço do trabalho torna-se recompensador a partir do momento em que ele faz com que o objeto que o trabalhador manuseia com suas mãos transcenda - embora Bachelard dirá literalmente que o artefato é posto em "nova ordem". O verbo transcender surge como uma opção que se aproxima mais do que pretendemos investigar no cinema de Terrence Malick por meio dessa experiência imaginativa que Bachelard confere à relação do homem com o trabalho.

A atitude dos personagens de Malick em relação ao labor consiste numa importante franja de sua estética. Em A árvore da vida, há o pai provedor (Mr. O’Brien), cuja maior proeza é a de moldar o caráter e disciplinar os filhos (e a esposa) com mão-deferro. Mão que toca o piano, que acaricia e que bate - no quintal, ele treina os meninos para aprenderem a socar. As mãos usadas como armas. Esse conjunto de ações de O'Brien pode ser comparado com o do ferreiro de Bachelard, cujo empreendimento envolve a matéria dura, introvertida. O objeto do devaneio bachelardiano permanece em luta renitente e, como O’Brien em sua cultura sulista-cristã-conservadora norteamericana, busca a máscula satisfação de exercer mudança pelo gesto ${ }^{43}$. A gênese bíblica metaforizada pelo mesmo filme instiga a dialética original de sua premissa: os caminhos

\footnotetext{
${ }^{43}$ Esta satisfação é exemplificada por Bachelard (1991, p. 30) ao tratar da psicanálise material do desejo do entalhe de uma faca na madeira, um "instinto sádico" ou "uma primazia das imagens seditoras" conforme descrito por Gerges Blin.
} 
do homem e os caminhos da natureza. O homem-ferreiro em Pitt e o homem-oleiro. Este último, pela vontade bachelardiana, pertence ao reino da matéria mole. Lida com a argila, a molda sem golpes, com cuidado. A figura do oleiro pela tradição do Velho Testamento está intimamente relacionada com o Deus cristão-criador. "Mas agora, ó Senhor, tu és nosso Pai, nós somos o barro, e tu o nosso oleiro; e todos nós somos obra das tuas mãos" (BÍBLIA, Isaías 64:8).

Quão importantes são essas mãos para Malick... Nelas incide certo devanear bachelardiano, como vemos em Terra de ninguém, por exemplo: o pai de Holly (Warren Oates), um pintor, restaurador de placas e outdoors, é sempre interrompido enquanto trabalha - na maioria das vezes por Kit, o improvável e indesejado candidato a genro. A pintura permanece inacabada e o tranquilo deslizar dos pincéis sobre as superficies sugere eternidade e movimento àquela obra. Há, portanto, um sinal de beira de estrada cuja missão está porvir, assim que concluído estiver o trabalho. Estamos diante de um objeto em processo de aceleração, mas que não nos permite acompanhar sua inércia. Seria este um reflexo do próprio processo braçal do pai de Holly. Os próprios Kit e Holly se dedicarão ao trabalho da subsistência durante sua fuga. Kit precisa caçar, Holly se gaba por percorrer algumas milhas carregando lenha para a fogueira - sua primeira atividade braçal é digna de louvor. Contudo, o mais-que-ser da obra e do trabalhador se limita à insignificância de suas existências.

Embora o comentário último pareça descarregar algum juízo de valor sobre o personagem e sua relevância na trama, a nossa intenção passa por outra abordagem: permitir criar atrito entre a questão da energia do trabalhar com vaidade tratada pelo desconhecido autor eclesiástico na Bíblia. Acrescentamos, assim, ao lúgubre fím do objeto, tomado pelo trabalhador para tornar-se mais do que o nada que era antes, um processo que há de fortalecer o nosso exercício da teopoética, pelo qual propomos uma forma de se ver o mundo mais "divinamente". Ou, nas palavras de Rilke, "em vez de tentar ver Deus, como futilmente muitos têm tentado, eles deveriam tentar ver como Deus vê" (RILKE, 1947, p. 146). Acrescentaríamos ainda o agir como Deus age, como espelho de um criador (à imagem e semelhança) em uma obra instrumentada pelas próprias mãos.

A realidade e a verdade estão muito distantes, incompreensíveis e profundas; que ser humano terá a 
capacidade de descobri-las? (BÍBLIA, Eclesiastes $7: 24)$

Partindo dessa proposta bíblica da intangibilidade de uma verdade, nos descolamos da visão filosófica cartesiana da vontade (aquela que permite respostas e afirmações) para adentrar o mundo corpóreo humano alinhando-o ao pensamento bachelardiano, para quem a vontade se associa ao inconsciente e qualifica o caráter imaginário como energia do espírito científico. Para Bachelard, a imaginação deve ser mediatizada pelo corpo biológico, desde que submetido a um tensionamento. Ao conhecimento bíblico, tudo é vaidade. O trabalho, a existência imanente... tudo. Para o segundo, o homem fora cuspido de sua própria existência por um capricho da criação e a natureza não procedera de forma consequente e mecânica tal como descrita por Darwin. De ambos os lados, de todos os lados, resta apenas a expressão. A expressão criadora (ou poética), que permite ao homem tocar o vento por entre os dedos, apalpá-lo. Comungar com ele, mas não aprisioná-lo. Agarrá-lo, afinal, o tornaria como as riquezas terrenas: efêmeras. Ou como o labor diário - um incessante correr atrás do vento, segundo o livro da sabedora eclesiástica.

Voltemos ao exemplo de Mr. O’Brien em A árvore da vida. O típico chefe de família conservadora do meio-oeste norte-americano nos anos 1950, conforme já o introduzimos. Seu emprego de corretor de imóveis permite-lhe uma boa vida, porém, a felicidade lhe é negada. A trágica morte do filho em campo de batalha the endurece ainda mais o rosto sisudo. Não há mais espaço para brincadeiras lúdicas com Mr. O’Brien. As mãos estão ocupadas pelo suor e pelo pesar. O teólogo Peter J. Leithart propõe interessante contraponto do caminho da natureza perseguido por Mr. O'Brien diante da atitude da enlutada Mrs. O’Brien, representando o caminho da graça:

Durante um passeio de carro, um dos filhos coloca a mão para fora da janela brincando com a brisa passageira, como sua mãe na cena de abertura. Ele está mais interessado em sentir o vento atravessandolhe os dedos do que em ocupar suas mãos de vitórias (LEITHART, 2013, p. 61, tradução nossa ${ }^{44}$ )

\footnotetext{
44 No original: "During a car ride, one of the boys has his hand out the window playing with the passing breeze like his mother in the openin scene. He is more concerned with feeling the Wind through his fingers than He is with filling his hands with winnings".
} 
Segundo Bachelard, a integridade da matéria dura (o ferro, a madeira) se vulnerabiliza diante não apenas da mão armada, mas "pelos olhos ardentes, pelas injúrias". A imaginação das forças é mediatizada pelo corpo vivo e determina no devaneador os matizes da vontade de poder social. Quando Smith e os demais exploradores britânicos atracam na costa leste da América em $O$ novo mundo, após a

primeira vista da nova terra prometida (a ser conquistada a sangue e fogo), tem a atividade braçal como primeiro pensamento: "Essa terra é boa para todos. E a um único custo: o trabalho. Trabalho árduo". Esse labor da conquista, da vitória reclama vítimas para além dos objetos. Os índios, dominados (e dominadores em outro momento), articulam forças na ordem das ferramentas: os tacapes e flechas contra as armaduras e armas de fogo. Os corpos se tornam objetos (a faca que entalha e a madeira ferida). $\mathrm{O}$ embate ganha, então, pela ótica de Malick, um plano transcendental: ao encontro/salvamento de Smith pela princesa Pocahontas, o desafio da linguagem impõe às mãos uma nova disciplina. Do aprendizado. Smith aprende a usar arco e flecha, a caçar... Um novo trabalho o chama. A madeira agora é quem entalha a faca.

\subsection{Devaneios sobre o ato de cavar poços no deserto}

Após esse percurso pelos sentidos do gesto e do trabalho, ambos ligados à vocação da mão como instrumento de transformação e glorificação, voltemos ao complexo de Jonas, ou mais especificamente, ao que nos traz de riqueza poética o devaneio da profundidade que esta ilustração de Bachelard nos municia para pensarmos o cinema de Terrence Malick. Seu atual diretor de fotografia, Emmanuel Lubekzi, em relato à sua história oral, diz que Malick lhe pediu para não se preocupar com o que está sendo falado em cena, para buscar a alma do que é encenado. Isso não significa que o diretor adota um sistema arbitrário para seus roteiros, ainda que pareça ou mesmo que às vezes o faça. Antonio Banderas, escalado para seu mais recente longa-metragem, Cavaleiro de copas (2016), disse em entrevista ao site norte-americano Collider (collider.com) não ter tido ideia do papel que desempenhou. Basicamente, Malick o entregou o texto de um monólogo e lhe pediu para improvisar. Não tentamos aqui justificar o exercício poético de Malick por meio de uma investigação de seu método de 
trabalho (também não negamos essa posibilidade), contudo essa informação permite-nos partir de um pressuposto de que o resultado na tela esconde silêncios, intenções e qualidades que podem ou não ser trazidas à tona. Dos movimentos da profundidade, um devaneio a que nos deteremos será o do escavador de poços no deserto.

Olhando para todo o trabalho realizado debaixo do sol, poucas tarefas concentram ao mesmo tempo tanta inutilidade e valor como a de cavar poços artesianos de água no deserto - há esperança de saciar a secura da terra, embora sua índole seja de esterilidade. É preciso enxergar para além da areia, buscar no íntimo da Terra a vivacidade de suas veias. O caminho até o lugar para a escavação é sempre intuitivo. Encontrá-lo é desapegar da aventura logística e escutar o ventre do deserto, a agitação da água, ouvir além da audição, como Bachelard sugere: “Ouvindo certas palavras, como a criança ouve o mar numa concha, um sonhador de palavras escuta os rumores de um mundo de sonhos" (BACHELARD, 1990, p. 48). O movimento sugerido aqui não é apenas o de capturar a mensagem, mas de se deslocar até o interior do objeto a que se pretende ouvir. Por vezes, ressoará como engano; por outras desencavaremos a história de um povo ou sentido de um ato. "O devaneio, o moroso devaneio, descobre as profundezas na imobilidade de uma palavra. Pelo devaneio acreditamos descobrir numa palavra o ato que nomeia" (BACHELARD, 1990, p. 47).

Cavar poços também se traduz em uma das mais essenciais contendas da humanidade: a disputa pelo poder. Água, petróleo, ouro... tais coisas estão escondidas e precisam ser escavadas. Um dos mais famosos poços escavados por Isaque, um exímio cavador dos tempos bíblicos, chamou-se Ezeque, que quer dizer contenda. Seria preciso perfurar mais e mais profundamente para extrair do poço a água pura, pacífica. Em sua lida de escavação de poços, Isaque também abriu o poço de Sitna, que significa ódio (mesma raiz para Satanás, no hebraico). A contenda persegue Isaque. Ele busca uma água purificada, abençoada. Lembramos mais uma vez de Malick. "A água vai se erguer em chamas. Os bons irão ao céu e escaparão de todo aquele fogo", profetiza Linda, logo no início de Dias de paraíso. Neste filme, seu irmão, Bill, e sua cunhada, Abby, estão a caminho de abrir mais um poço no deserto escapando da contenda do serviço nas minas de carvão. Encontrar água na profundeza seria essa metáfora em busca do sustento e da purificação. 
Os personagens de Malick carregam culpas e pesares por todo o tempo. Os soldados em guerra de Além da linha vermelha fornecem ilustração apropriada. Em guerra, o espírito do soldado carrega a missão de contender e se depara com a frustante limitação que se impõe sobre a vida humana (sua psiqué e sua força física). "Fechado em um túmulo. Não consigo levantar a tampa. Desempenho um papel que nunca concebi”, reflete o tenente-coronel Gordon Tall (Nick Nolte). Ele é o pastor do rebanho em solo inimigo. A força e a deteminação diante dos liderados não correspondem ao sentimento que se retorce em seu âmago. Ele não consegue antever os próximos passos de seu pelotão. Sua fé foi rompida e a natureza não é mais uma aliada (“Olhe para esta floresta. Olhe essas videiras, a forma com elas se entrelaçam, engolindo a tudo"). A única ordem que lhe parece possível é: “Avancem! Avancem!”. O desolado sargento McCron (John Savage) recorre à direção divina: "Me mostre como ver as coisas da forma como você vê’. Talvez a perspectiva de Deus permita ao homem enxergar a profundeza.

Em sua lida de escavador de poços, Isaque não cessa de abrir novas fontes de água. Passa por desertos e vales (ambos utilizados biblicamente como metáfora para a dor e para o sofrimento), até que encontre seu lugar de amplidão, de onde extrairá a seiva da Terra. Eis que Isaque encontra a água de Reobote. O poço levaria este nome por sua abundância e por não mais haver contenda. "Agora, com efeito, o Senhor nos deixou o campo livre, e tivemos frutos da terra" (BÍBLIA, Gênesis 26:22). Deus revelaria a Isaque sua Berseba, um poço de promessas e alianças. Mrs. O’Brien, em A árvore da vida, coloca-se à espera de sua Berseba: "As freiras nos falaram que ninguém que anda pelo caminho da graça terminará mal”.

A Malick interessa muito o fim dos seus personagens, os caminhos que seguem. O conceito de heroísmo não distingue bem e mal. Do mesmo modo como há poços abençoados, há aqueles cingidos de maldição. Se Kit, em Terra de ninguém, e Bill, em Dias de paraíso, cometeram crimes, ainda que sendo responsabilizados por eles sua fortuna espiritual fora alcançada. Ambos chegam até as águas. Bill morre ali. O novo mundo propõe um amor impossível ou que é negado aos amantes. Mais uma vez a água restaura-lhes a esperança ao final. $\mathrm{O}$ encontro de Jack, em $A$ árvore da vida, com sua família - ou melhor, com seu passado -, fertiliza graças às ondas que devolvem a seiva à terra na praia. Em Além da linha vermelha, a guerra passa e a natureza permanece. 
Vemos os nativos voltando a transitar pela ilha em seus barcos e, mais importante, concluímos que a vida renasce ali onde a morte prosperava ao despedirmos do filme com a imagem final de uma planta na poça rasa em meio a bancos de terra. Marina, em Amor pleno, se mistura à grama molhada, revive, e contempla ao longe, refletida no rio, a imagem de um castelo, que resiste ao tempo.

A profundeza, aprendemos com o instante poético de Bachelard, conclama a altura. Afora os simbolismos da água, Terrence Malick se utiliza da água, de suas potências de imagem-cristal (tal como veremos no capítulo a seguir) para imprimir suas perspectivas. Malick propõe afundar a câmera para capturar a altura. Na cena de abertura de Além da linha vermelha, após a submersão do crocodilo, olhamos da raiz para a copa da majestosa árvore. Esse movimento será utilizado em todos os filmes a seguir. Bem como quando vemos as crianças nadando na ilha de Guadalcanal. Observamos de dentro da água, por baixo. Das profundezas, a câmera de Malick busca transmitir a sensação deste duelo entre extremos. Esse dilema da altura revela-se na natureza dos planos. A câmera está sempre mirando o céu: de dentro d'água vemos a luz do alto e o azul líquido se confunde com o azul aéreo. As copas das árvores são vistas por baixo e permitem-se invadir pelos raios solares. Neste momento vemos sua teopoética: quando o espaço que separa a humanidade do divino rompe a noção de altura e de profundidade para permitir que do fundo do mar ou da raíz de uma árvore toque-se o firmamento, como se não mais houvesse um espaço que separa o solo do céu ou mesmo o homem de Deus. "Que seria a ideia de pureza sem a imagem de uma água límpida e cristalina, sem esse belo pleonasmo que nos fala de uma água pura?” (BACHELARD, 1989, p.15) 


\section{Soli Deo gloria: o rito da paisagem}

Sinta-a, com suas duas torres, tremer com todos os seus tons azuis no ar imenso; veja como responde, em suas mil nuanças de azul, a todos os movimentos da bruma. Ela possui asas, azuis de asa, ondulações de asas. Um pouco de seus contornos evapora-se e suavemente desobedece a geometria das linhas

Gaston Bachelard sobre a Catedral de Rouen, de Claude Monet 
Pudera um gesto de louvor ser traduzido em cores: as mãos alçadas aos céus, das quais falamos no capítulo anterior, se estivessem eternizadas, ou embalsamadas para usarmos um termo de Bazin no que se refere ao tempo do cinema... Captuar aquela essência do filme em quadro permitiria alcançar a profundeza de um pensamento imaginado acerca dos elementos que compõem uma determinada mise-en-scène. Mas o gesto rejeita o estatismo. Seu ato de transgressão e sua postura poética dependem do movimento. Talvez isso é o que o diretor de cinema ou de fotografia pense ao elaborar seus planos. A memória líquida do movimento não poderia se deixar capturar mumificar-se. Se almejarmos não o gesto na tela - do personagem, da natureza, ora, de todo o universo ficcionalizado ali no enquadramento escolhido -, mas o olhar, podemos criar um devaneio de propriedades aquáticas às quais não se deve obedecer nem o tempo embalsamado ou a figuração da pintura ou a do quadro fílmico.

Essas águas a que recorremos devem cumprir funções ambíguas e complexas. Esperemos delas imagens translúcidas. Agitemos os fios do tecido de sua superfície e temos uma experiência não mais das entranhas de suas profundezas, mas uma distorção do que é refletido, uma deformação de sua beleza exterior. Esperemos pela noite e ela nos trará a escuridão da água, seu lado misterioso, que oferece perigos ainda piores que os da caverna devido à sua fluidez. Retirar um pedaço de água de seu todo modifica sua estrutura e, em um universo microscópico repete suas façanhas: permite ver seu âmago, desfigura-se, derrama-se, molha, seca. Extrair da água sua força poética é, portanto, um exercício que cabe ao observador - seja ele o pescador, o sedento ou o próprio poeta em sua condição narcisista ("a água amorosa", como definiria Bachelard a esse respeito). Mas não prevemos nos ater às tantas qualidades da água para o devaneio. Propomos buscar uma reflexão sobre os aspectos contemplativos de sua estrutura.

A simples visão, a mera contemplação dos espetáculos da natureza parecem impor, também elas, imagens diretas. Objetar-se-á, por exemplo, que inúmeros poetas, inspirados por uma visão tranquila, falam-nos da beleza láctea de um lago aprazível iluminado pela lua. (BACHELARD, 1989, p. 124)

Bachelard insiste que o papel do poeta não resume-se a propor uma determinada 
imagem, mas provocar o epectador para deduzi-la. Para isso, portanto, a imagem precisa ser construída com elementos fluidos. Ao observarmos no cinema, em obras como as do diretor Terrence Malick, como se trata as paisagens, neste sentido, encontramos uma complexidade que nos permite buscar ou ler poesia em seus subtextos e desenquadramentos de uma experiência cinematográfica com aspirações à pintura. Quando o horizonte das Badlands de Montana em Terra de ninguém se aproxima, a terra vermelha, a ventania, o borrão de fogo que mistura terra e céu ao fundo das tomadas da sequência de road movie, o que se enxerga não é uma mera escapada para o oeste norteamericano. Há um julgamento divino que vai pesando sobre Kit (Sheen) e Holly (Spacek) a cada quilômetro em que se distanciam da tranquilidade de Fort Dupree (South Dakota). Cabe a Kit e a Holly a expectativa da redenção que se aproxima de forma brutal. Há uma consciência de que poderiam não sair vivos dessa jornada. O mesmo destino se desenha para Bill (Gere) e o Fazendeiro (Shepard) em Dias de paraíso. A morte é iminente. O fogaréu nos campos de trigo pintam na tela do espectador uma escatologia para o amor proibido entre os "irmãos" ou para o golpe perverso dos amantes - e que logo são traídos pelos próprios sentimentos. Abby (Adams) passa a amar mais o Fazendeiro a quem the interessa somente a herança; Bill pragueja contra a fortuna vindoura que lhe ceifou o amor. Ou seja, ainda que haja uma narratividade a mediar a interação do olho com a tela, a paisagem se impõe como uma inegável potência do discurso fílmico.

Ao tratar da agitação da água - ainda que fracamente balançada -, Bachelard aponta para o reflexo leitoso que há de fazer manifestar o que estamos chamando de um rito da paisagem. Este nada mais é do que a superfície aquosa incutida de certa perturbação que já não mais representa o reflexo da paisagem vista, senão a transforma.

Para que a imagem láctea se apresente à imaginação diante de um lago adormecido sob a lua, é preciso que a claridade lunar seja difusa; é preciso, em suma, que a água passe da transparência à translucidez, que se faça docemente opaca, que se opalize. (BACHELARD, 1989, p. 125)

Convocar um ritual de paisagens no cinema - recortando pelas expressões dos filmes de Terrence Malick - não dispensa determinado aspecto litúrgico do olhar. Para entender o olhar, devemos recorrer à sua primazia. Como Bachelard nos orienta, essa função dependerá do ser imaginante, cujo olhar protagoniza o ato de sublimação do 
objeto contemplado. Uma domesticação desse olhar lhe permitirá encontrar os elementos familiares, reconhecer as cores e as sombras e percorrer os limites da imagem proposta. Para nosso rito, devemos nos atentar à representação, ou seja a "função do olhar", como diria Aumont. Não se trata de buscar a representação do real na tela de um quadro, mas de um desejo de investigação e descoberta.

Olhar a natureza tal como ela é, isso se aprende. A questão não é a de uma objetividade qualquer (...) mas, nesse esforço para apreender, a um só tempo, o momento que foge e compreendê-lo como momento fugidio e qualquer, o que se constitui é o ver: uma confiança nova dada à visão como instrumento de conhecimento. (AUMONT, 2011, p. 51)

Falamos aqui de uma matriz cinematográfica, mas almejamos relacionar as questões relativas à paisagem à fonte primeira historicamente, que é a da pintura sobretudo a impressionista. Aumont mesmo nos livra de um longo tratado acerca das coincidências e diferenças entre ambos em seu trabalho de fôlego que aqui citamos. Entretanto, seria adequado levantar novamente a pergunta: em que se difere o quadro da pintura e o quadro de um filme? Aumont tratará de entender a fundo as diferenças, mas não sem antes de partir de uma premissa de que ambos correspondem a um registro geométrico. "O que não vem da geometria é apenas a luz, o que permitirá se explorar as possibilidades metafóricas do quadro" (AUMONT, 2011, p. 62).

Se concluímos que o quadro serve ao propósito de limitar o campo de produção da obra pintada ou da cena filmada, não precisaríamos diferenciar as duas plataformas (cinema e pintura) no campo da fruição da imagem. Outra semelhança entre ambos, a saber, é de que esse mesmo quadro busca uma centralidade da representação do objeto narrado, fotografado ou pintado. A qualidade que devemos destacar, onde reside a chave que muda os códigos da percepção, é o díptico espaço-tempo. O cinema, portanto, não rivaliza com a pintura. Antes, a transcende (no sentido material). Para Aumont, a paisagem se resumira, assim, a um estado de alma - podendo ocorrer em ambas as artes. Ou, como reflitiria Eisenstein, seria a natureza vista através de um temperamento - os estados de espírito do pincel ou das paletas fotográficas da objetiva. "O cinema alcançou a pintura, ou, antes, ele a pronlongou" (AUMONT, 2011, p. 70). 
Ao falarmos do paisagismo que Malick nos oferece, não estamos provocando uma comparação com a tradição da pintura paisagista de Canaletto, cuja ávida crítica de Ruskin se impõe ao acusá-lo de “exercer a imitação". Também não tentamos desqualificar o propósito do artista. Ainda mais se levarmos em consideração o fator narrativo em que as paisagens de Malick ocorrem, guiadas por uma montagem e um trabalho sonoro que insiste em avisar que há mais para ser visto do que aquilo que cabe na tela. Malick não busca ingenuamente cultivar o impressionismo francês ou o figurativismo italiano, como no nosso exemplo - não limita sua câmera a uma questão de perspectiva, de ponto de vista.

A pintura de Malick se interessa pelo estado poético do quadro em repouso ainda que compreendamos toda a complexificação que o cinematógrafo insere nesta relação apressada do cinema com a pintura. No entanto, também entendemos que a mediação da câmera induz a um processo contemplativo que originalmente seria prerrogativa da pintura; Malick recorre a uma espécie de figurativismo, dada a intenção estilística. Tome uma gôndola de Canaletto e siga até o fundo do quadro. Há uma porção de céu que mede forças com as águas e supera as construções urbanas de Veneza. Certamente o azul (desde suas tonalidades mais acinzentadas à paisagem completamente nubilada ou noturna) tem algo a dizer, como reparou Gaston Bachelard na obra de Monet no prólogo deste capítulo. Ao permitir uma contemplação celeste, Malick permite que o azul invada e modifique seus interiores. Este azul a que nos referimos não é necessariamente uma cor, mas um permanente reflexo do estado de espírito da natureza diante da vida humana. "Em Além da linha vermelha os personagens amam, lutam e morrem em emaranhados de uma paisagem verdejante ao estilo do Éden" (EVERSTON apud TUCKER e KENDALL, 2011, p. 101, tradução nossa ${ }^{45}$ ).

Se há arbitrariedade em Canaletto ao escolher nubilar sua paisagem ou dissipar e recolher as nuvens por sobre os labirintos do Adriático, não importa para o devaneio aquático. $\mathrm{O}$ que o limite do quadro permite não prescinde de narratologia, mas busca cumprir uma função de subserviência ao olhar a ele lançado. Quando Kit, em Terra de ninguém, lança um balão ao céu, o observador está dispensado de conhecer sua jornada.

\footnotetext{
45 No original: "In the Thin red line the characters Love, fight and die in tangles of Edenlike greenery".
} 
O balão vermelho em um fundo azul nada mais é do que o desejo despertado pelo ímpeto do fotógrafo em nutrir uma paisagem ritualística. Em todos os filmes conseguintes Malick adotará esse compromisso, essa relogiosidade cerimonial da câmera respirando momentos fora de uma história, recorrendo a temas familiares, perturbando a cristalinidade do reflexo para que as paisagens contem suas próprias histórias. Portanto se Canaletto, ou Malick, "imitam", a imperfeição de seus traços propõe uma mínima agitação à visão que pode lhe imprimir um caráter transcendente. Ao refletir sobre a tarefa de registrar a vida real (e aqui ele fala especificamente do cinema), Tarkovski suspeita das limitações tecnológicas. "Falta à cor reproduzida por meios mecânicos o toque da mão do artista (...) A partitura cromática do filme, com o seu próprio padrão de desenvolvimento, está ausente, subtraída ao diretor pelo processo tecnológico" (TARKOVSKI, 2010, p. 166).

Embora Tarkoviski tome essa reflexão para questionar o caráter da produção, as relações interpessoais no set e a responsabilidade do diretor, não podemos deixar de notar sua ênfase em preservar os contornos do artista como baluarte de tal expressão cromática. Cabe à artesania do construtor de paisagens indicar a proporção de seu azul e os limites de suas sombras. "Paisagem é importante para os filmes de Malick não apenas por suas possibilidades de esplendor visual, mas porque as ideias do diretor são expressas por meio de sua representação da natureza" (SILBERMAN apud PATTERSON, 2007, p. 164, tradução nossa ${ }^{46}$ ). Na biografia oral de Malick, o já falecido diretor de fotografia Néstor Almendros (ganhador do Oscar por Dias de paraíso) acrescenta algumas informações elucidadoras acerca do método de Malick para filmar paisagens: a superexposição do céu, queimado e quase nada azul. "Como Truffaut, Malick segue a corrente de se eliminar cores. Céu azul o enfada, o que é compreensível quando vemos cartões-postais ou folders vulgares de viagem" (MAHER JR., 2014, p. 77, tradução $\left.\operatorname{nossa}^{47}\right)$.

A crítica que Aumont faz ao lugar-comum da fotografia e da pintura ao centrar-se

\footnotetext{
46 No original: "Landscape is important in Malick's films not only because of the possibilities for misual splendor, but because the director's ideas are expressed through his reprsentation of nature".

${ }^{47}$ No original: "Like Truffaut, Malick follows the current trend of eliminating colors. Blue Sky bothers him, which is understandable when it makes landscapes look like picture postcards or vulgar travel brochures".
} 
na analogia e na abstração pode ser extendida ao cinema contemporâneo. Insistentemente tomadas com matrizes semelhantes às de Malick, de emoldurar a paisagem no quadro fílmico, pretendem contemplar a natureza tal como ela é, via uma representação óbvia de ostentação da natureza, revestido de uma beleza de cartões-postais. Malick, como vemos, carrega em suas paisagens um desejo lírico e espiritual. E, por trás de tudo, esconde um anelo de exprimir-se de forma natural, interferindo minimamente na luz. Malick, se tivesse de se afiliar a uma escola artística, certamente se colocaria a serviço do impressionismo, embora seu método sofresse influência da pintura ao ar livre do início do século 20, dada a sua busca por autenticidade. Não o seria, devido ao fator sentido. Seus planos-pinturas requerem o pretexto de um simbolismo. "O impressionismo é, talvez, de fato, a última tentativa para conjugar, em igualdade, na representação, uma certa fidelidade visual ao real da inscrição de um sentido" (AUMONT, 2011, p. 92).

A centralidade da representação é tão característica da pintura como da construção visual do filme. A árvore dos tamancos (1978) poderia muito bem traduzir esse espírito, mostrando que há outras camadas de paisagem na linguagem cinematográfica. Neste filme italiano ganhador da Palma de Ouro em Cannes, o próprio diretor, Ermanno Olmi, imprime seu olhar paisagísitico centralizando a vida humana. Somos um detalhe de um universo muito maior do que nós. As sequências em que personagens se locomovem de um lugar para outro costumam vir sempre acompanhadas de um certo distanciamento, a permitir que a paisagem se pronuncie, sob uma paleta de cores granulada, com baixa luminosidade, derramando os tons cromáticos em sobreposição, formulando uma unidade das pessoas com as árvores e os bancos de palha. Não raro, a comunidade rural filmada por Olmi remeterá às paisagens divisionistas italianas, como às das obras de Giovanni Segantini (1858-1899) ou de Giorgio Kienerk (1869-1948). Não fazemos uma referência explícita à técnica do pontilhismo, cujo método fundamenta essa escola em que ambos se inspiram, mas realizamos uma aproximação com esses pintores neo-impressionistas italianos (Segantini nasce austríaco) por suas propostas cromáticas e temáticas, de se abordar a vida no campo ${ }^{48}$. A câmera de

\footnotetext{
48 Segantini sofre influência do naturalismo romântico de Jean-François Millet, cujo interesse é a representação do trabalhador rural.
} 
Olmi exerce essa porosidade divisionista para ilustrar seus campos e envolver seus personagens como que em uma sobreposição em relação à natureza.

Olmi abordará de forma singular, com isso, uma temática religiosa. À tradição dos irmãos Tavianni (Pai patrão), a rigidez da educação clerical que os filhos de Battisti (Luigi Ornaghi) recebem e as relações de trabalho opressoras deixam claro o caráter serviçal dos personagens de Olmi e do discurso narrativo. Em A árvore dos tamancos, remontamos ao Éden, quando o patrão proíbe Battisti de tocar em determinadas árvores do senhorio, com a ameaça de ser expulso de casa. Eis que aquelas são as árvores de onde ele poderia retirar a matéria-prima para confeccionar um novo par de tamancos para seu filho. As paisagens buscam versar sobre Deus.

Na obra de Malick, há uma luz mais difusa. Em Além da linha vermelha, o norteamericano espalha seus quadros com intuito de reverberar a constante busca pela paz. Não a que se faz pela guerra na Oceania, mas a única possível: a paz interior. Ou, como faz Olmi também, deixar que a luminosidade (e a obscuridade) da fotografia paisagísitca permita que se enxergue a glória divina. "Aqueles que vivem autocentrados ignoram a glória que brilha em volta deles. É uma glória divina, mas que brilha por meio do mundo natural (...) A câmera de Malick, enquanto isso, nos seduz ao caminho dessa graça" (LEITHART, 2013, p. 50, tradução nossa ${ }^{49}$ ). Esse dar a ver da paisagem de natureza não está apenas se confundindo com a poesia da imagem. Isso não deve significar que toda representação da natureza carrega o simbolismo da divindade, mas dado os elementos combinados em retratos como os de Malick - e também de Olmi - conseguimos perceber uma intenção de discurso sobre o divino, como ao contemplar a Ave Maria a trasbordo, de Segantini. Embora a temática de Sagantini trate de Nossa Senhora, impossível não notar ao fundo do quadro o porvir do crepúsculo. Uma luz do sol que se despede ao horizonte ainda com força para refletir os carneiros esgueirando-se do barquinho para beber água e a mãe ninando o bebê. Não vemos Deus, mas podemos perceber um elemento extrassensorial que, traduzido pela dimensão de uma estética da experiência humana, poderemos chamar de teopoética. Nas paisagens de Malick essa presença

\footnotetext{
${ }^{49}$ No original: "Those Who live self-centeredly in the way of nature ignore the glory tha shines around them. Is is a divine glory, but it shines through the natural world (...) Malick's câmera meanwhile seduces us into the way of grace".
} 
teopoética se impõe com frequência. Voltemos a Além da linha vermelha. Trata-se de um filme de guerra, com todas as suas paisagens de guerra: a floresta, a clareira da armadilha, o campo de concentração, o front de batalha. Contudo, Malick insere a ação humana do guerrear absorta em um universo pastoril, remontando ao mais simples e puro dos elementos: o amor.

Como uma espécie de sermão de fogo visual [em referência à figura de Buda no campo japonês], a imagem oferece outra visão de transcendência que acompanha as idílicas imagens de luz e água que Malick introduz no início do filme e nas recorrentes tomadas de pássaros e da lua, que indicam um reino de paz além da paisagem de guerra. (SILBERMAN apud PATTERSON, 2007, p. 171, tradução nossa ${ }^{50}$ )

Malick apresenta na perspectiva dessa "pintura" de guerra uma possibilidade de transfiguração para um esplendor alcançado somente pelo recurso da imagem-movimento e dos meios técnicos dos quais o cinema se imbui para "prolongar a pintura", como já disse Aumont. Como experiência, portanto, a pintura fora superada pela criação do cinematógafo. Aumont conclui que o efeito visual cinematográfico traduziria com mais eloquência do que nas artes plásticas a luz impalpável (matéria visual por excelência), o irrepresentável (a habilidade de se fazer ver aquilo por meio da técnica) e o fugidio, uma síntese temporal, o efeito mumificante a que Bazin se refere ao "embalsamar o tempo" (AUMONT, 2011, p. 35). No entanto, essas categorias interessam se buscarmos revelar as façanhas por trás do que ele chama de "reversão do tempo criatorial". Ou seja, não cabe ao espectador a tarefa de reconstituir os procedimentos do artista. Seu tempo é o tempo do olhar e o percurso a ser caminhado por esse olhar está ligado às possibilidades do devaneio. Num emaranhado de imagens sobrepostas, numa sombra ou em figuras abstratas pode-se revelar a alma da paisagem. O olhar pode deduzir, pode rever e pode até mesmo ser influenciado para uma exploração dirigida do campo de visão. Não vamos nos estender para as condições que intervêm na visada do espectador. Interessa-nos mais capturar os instantes plenos da poesia, ou entender como a alma do poeta consegue projetar-se para dentro de um estado de percepção.

\footnotetext{
50 No original: As a kind of visual fire sermon, it offers another view of transcendence to go with th idyllic images of light and water Malick introduces at the star and the recurring shots of birds ando $f$ the moon tha indicate a realm of peace beyond the landscape of war".
} 
É o espectador que está mergulhado numa felicidade tão física e tão segura que o leva a lembrar-se do mais antigo bem-estar, do mais suave dos alimentos. Por isso o leite do rio nunca há de ser gelado. Nunca um poeta nos dirá que a lua de inverno derrama uma luz leitosa sobre as águas. A tepidez do ar, a doçura da luz, a paz da alma são indispensáveis à imagem. Eis os componentes materiais da imagem. Eis os componentes fortes e primitivos. A brancura só virá depois. Ela será deduzida. Apresentar-se-á como um adjetivo conduzido pelo substantivo, depois do substantivo. No reino dos sonhos, a ordem das palavras que quer que uma cor seja branca como o leite é enganadora. $\mathrm{O}$ sonhador toma primeiro o leite, seu olho sonolento vê depois, às vezes, a sua brancura. (BACHELARD, 1989, p. 125)

O caminho a que Bachelard nos leva é crucial para apontar os caminhos dos nossos dinossauros. A grande revelação da poesia, do sentido do ser, não deve ser definida pelo olhar do espectador, mas pela insondabilidade da imagem vista. Ao mesmo tempo, não a biografia ou o discurso formal narcisista do poeta que nos permitiria também objetivamente compreender o estado lácteo da água. Na senda de elaboração de suas paisagens, Malick, portanto, recorre às potências tecnológicas do cinema para alcançar algo que pode estar fora do quadro ou escondido no subtexto. A pintura passa a se desprender da geometria e constituir-se - por meio de movimento e uma estilística própria - desenhos invisíveis.

Antes de avançarmos no sentido do invisível, devemos pincelar uma noção acerca do estatuto da imagem. E, embora, a imagem tenha em si diversos estatutos pósplatônicos (historiográficos, estéticos, psicológicos etc.), nos atemos ao quesito da atividade mimética, sem necessariamente passarmos por conceitos como de simulacro. Fazemos um uso modesto desse estatuto especificamente no cinema de Terrence Malick, com o único propósito de entendermos como ele dispõe sua representação da natureza, vaidade máxima do ritual paisagístico do diretor. Sua busca por uma verdade se origina, a rigor, de um método de capturar a própria verdade ${ }^{51}$ que passa pela técnica (uso de luz natural) e pela intuição (as longas horas de filmagem em que se estimula a espontaneidade dos atores e dos elementos naturais, da fauna e da flora). Ao tratar do

51 Citamos esse conceito cunhado por Tarkovski na página 20 da presente dissertação. 
estatuto da imagem de uma paisagem, relacionamos ao que Cauquelin chama de um momento preciso de verdade.

Não se trata da Natureza como princípio nem de sua relação com sua figuração sob a forma da paisagem, mas do princípio divino, o Deus cristão em três pessoas, e de sua figuração sob a forma de imagens a sua semelhança. Contudo, ao formular essa questão, e ao providenciar uma resposta para ela, é também a relação da natureza com sua representação que está posta. (CAUQUELIN, 2007, p. 68)

Almejar esse modelo divino - no qual se produz uma imagem em semelhança requer determinada artificialidade, uma perspectiva iconoclasta uma vez que seria mérito da obra singular do Gênesis pertence a um determinado criador, fazendo com que ademais experimentemos sempre a imitação da Natureza, ou a imitação de Deus. Se preferirmos, a imitação do imitador, o Deus encarnado como homem, sob o signo de uma nova criação, o ícone de Cristo. "Sede meus imitadores como o sou de Cristo", convoca São Paulo (BÍBLIA, I Coríntios 11:1). Malick desempenharia nessa mímese o papel do apóstolo. Ele não estaria buscando o traço icônico de sua "imitação da natureza", contudo a inferência que nos permite é a de considerar a pretensão de suas imagens, expressas nas construções das paisagens, esse traço que circunda o vazio e onde se esconde o mistério da presença divinal na imagem.

\subsection{Traços do invisível: da insondabilidade da imagem}

Consideremos novamente a água e seu propósito fluido. Sua prosódia seguindo um leito esgueirando-se até outras águas se anima com os obstáculos, aceita-os. A capacidade de absorção de formas desse elemento primitivo pode contornar as pedras, embelezar as árvores, ascendendo sempre a novos significados, a novas imagens. Seu poder transformador não é ilimitado - a não ser por sonho - mas seu movimento transcende seu curso com delicadeza a cada ameaça de rocha, exercendo o poder de transbordar. A este último efeito, de se exceder às margens, relegamos a metáfora para discutirmos a noção de desenquadramento. Ao tempo em que Terrence Malick compõe um cinema de paisagens, aproximando-se das primazias da pintura, criando um sistema 
ritualístico pontuado pela questão da natureza, os planos propostos pelo diretor também excedem a mera compreensão de paisagem. Dentro dela, há uma outra dimensão de imagem, espaços vazios ou desconectados, mais uma vez que não prescindem de uma narratividade. Há algo que está além do visível.

As águas dizem muito da natureza. Bonança e tempestade dançam sobre as paisagens líquidas promovendo momentos cristalinos e distorções oníricas. Private Witt (Jim Caviezel), em Além da linha vermelha, questiona a natureza: "Por que ela se volta contra si?" A metáfora é a Segunda Guerra Mundial, cenário das divagações e orações que ocupam os pensamentos de um grupamento americano na batalha de Guadalcanal. Antes da majestosa árvore em contra-plongée ocupar tela debaixo da "voz de Deus" (o off), ao início do filme, a paisagem se liquefaz. A água engole um crocodilo e mais tarde envolve os nativos das Ilhas Salomão e os próprios soldados em seu prisma cristalino. O oceano placentário da Mãe Natureza permite-nos navegar por uma importante divagação acerca da imagem contemplativa, ou desse rito que a paisagem natural impõe ao espectador de um filme. Falta-nos compreender como se constroi o plano como um todo, perturbado pelo movimento, pela montagem, pela luz e pelo som.

O plano não se contenta em exprimir a duração de um todo que muda, mas faz incessantemente variarem os corpos, as partes, os aspectos, as dimensões respectivas dos corpos que compõem um conjunto na imagem. Um se faz através do outro. (DELEUZE, 1990, p. 36)

Como vemos em A árvore da vida, a metáfora da origem das coisas reflete-se por entre os intensos feixes de luz que recortam cada momento em que a câmera contempla uma árvore, de baixo para cima. Vemos muito dessa opulência celestial nos enquadramentos da porção urbana e contemporânea narrativa do mesmo filme. Jack (Penn) ao subir e descer as escadas ou entrar e sair dos ambientes de sua casa e da empresa onde trabaha, o faz dentro de redomas de vidro. Até que ponto vemos demais? Malick permite que a luz invada até que estoure. A obscuridade da fotografia nos filmes do diretor norte-americano se compõem de excesso de luminosidade. Lembra a ilustração da cegueira de Saulo, antes que se tornasse São Paulo, o apóstolo. Quando Deus se revela a ele em forma de um clarão, a cortante luz divinal cerra-lhe a visão para que pudesse voltar a ver com novidade de olhar. 
Malick busca essa representação em seu cuidado com a luz. Isso explica sua obsessão pela luz natural estourada. Não se liga refletores e rebatedores nos sets de filmagem de Malick, em nenhum dos filmes. O movimento de câmera precisa obstinadamente buscar o estouro com o objetivo de captar uma sensação de naturalidade do movimento. Em Malick, percebemos um esforço diligente para naturalizar a paisagem. "À sua imagem", como no ensinamento criacionista. O modelo divino guia o modelo humano. $\mathrm{O}$ exercício proposto por Malick, portanto, não seria o de fazer à semelhança de Deus, senão buscar inverter o princípio em que todo homem seria provido de uma necessidade imanente pela relação com o transcendente. Malick, em suas imagens, propõe uma naturalização como se partindo de Deus para o homem, qual relato do Gênesis. Ou seja, a construção da paisagem nos seus filmes se preocupa primeiramente em apresentar a ação natural divina para então incluir o homem. Eis uma importante problematização:

Pode o princípio divino ser representado em uma forma sensível (visível)? Não, dirão uns (os iconoclastas), porque essa forma material trai a essência do divino e, ao propor a ilusão de uma similitude, faz o signo ser tomado pela coisa e conduz os cristãos à idolatria. Sim, dirão os outros (os iconódulos), porque nem toda imagem é necessariamente similitude ou visa à identificação do signo com a coisa. (CAUQUELIN, 2007, p. 69)

Esse apontamento nos dirige a enxergar uma realidade que aflora para além do quadro. A ideia de imagem-cristal, expressa por Deleuze nos permite encontrar um caminho acerca do visível e do invisível por uma ótica temporal para vislumbrarmos os traços ocultos na imagem de Malick. Essa noção corresponde a um tempo em estado puro, uma fração mínima de uma imagem-tempo constituída de natureza contraditória, unindo o atual (o momento, o presente, o visto) e o virtual (o insondável, o que é pronunciado por meio de um prisma). Os cristais de tempo em Malick se referem justamente a esta senda da luz natural, cujo dever é de se aproximar orgânicamente à realidade. Contudo, para que o faça, e para que se evite a representação horizontal da arte banal dos cartões Hallmark, imprime-se uma consciência difusa mediada pelo cristal de tempo e que "não se revela e não revela a fotografia do todo que permanece translúcida até que uma consciência, situada num lugar qualquer do plano de imanência, se constitui 
quando imagens de um tipo especial terão aparado ou refletido a luz, ao fornecer-lhe a tela escura que faltava atrás da chapa" (DELEUZE, 1990, p. 88). Malick não supera, contudo, o efeito desolador da montagem cinematográfica.

A mudança de plano, a mudança brusca, em geral, no cinema, foi uma das maiores violências jamais feitas à percepção "natural". Nada em nosso ambiente modifica todas as suas caracterísitcas de modo tão total e brutal quanto a imagem fílmica, e nada nos espetáculos preexistentes ao cinema havia preparado para tal brutalidade. (AUMONT, 2011, p. 103)

Convém observar que, ao apontar o choque da imagem-movimento, Aumont se refere a um tempo histórico, do cinema primitivo. Hoje, embora esteja superado o choque, a teoria da naturalidade mantém-se. O quanto o esforço de Malick em adotar sua luz natural e permitir o improviso ou que se espere o simbolismo da vida suscitar seu cinema não é comprometido com a montagem deveras apressada? Recorramos à ordem do "tempo ocular" (AUMONT, 2011, p. 85), a exploração do olho da superfície da imagem. Imagine a potência que uma paisagem no cinema precisa impor para concorrer com o instante do olho que explora cerimonialmente um quadro estático? O plano pode criar seus cristais e obter resultados perenes e efêmeros. A teopoética observada em Malick se alimenta de imagens intuitivas, cujos predicados correspondem ao risco da imagem ser descartada, embora com a esperança de que pemaneça. O que nos leva a entender qual é a natureza da própria imagem? Se é visível ou invisível?

A natureza da imagem é deixar algo ser visto. Em contraste, cópias e imitações são meras variações da imagem genuína que, como visão ou espetáculo, permite o invisível ser visto e imagina o invisível em algo alheio a isso... imagens poéticas são... não meras ilusões mas imaginações de que há visivelmente inclusões do estranho na visão do que é familiar (HEIDEGGER, 1971, p. 126)

Voltemos ao apóstolo São Paulo. A teologia recorre à metáfora da cegueira como via de encontro com a glória de Deus ou com a sua maravilhosa graça - "Was blind, but now I see, ${ }^{\natural 2}$. É no momento de cegueira espiritual que enxergamos o mundo material; o cingir dos olhos como revelação divinal restabelece o contato com o transcendente. $\mathrm{O}$

52 Verso da canção gospel Amazing grace, escrita por John Newton. 
invisível torna-se visível por meio de sua invisibilidade. Não devemos exigir do espectador que enxergue pelos seus olhos espirituais a presença de Deus no cinema de Terrence Malick, mas uma correta abordagem teopoética - por via da linguagem - nos permite despertar uma sensibilidade para ver o não-visto. No quadro fílmico, nos interessa sua qualidade centrífuga, na qual o olhar é guiado sempre no sentido do centro para as beiradas (ou além delas), a um lugar em que "pede, inelutavelmente, o fora-decampo, a fíccionalização do não-visto" (AUMONT, 2011, p. 111).

Em sua abordagem, Dias procura colocar o não-visto como um aspecto adjacente ao visível. Ora, o invisível não pode ser a negação do visível, senão uma camada possível do olhar "sempre pronto a aflorar e se nivelar a ele [o outro]" (DIAS, 2010, p. 225). Dias chama atenção para detalhes que podem passar desapercebidos pelo olhar acerca da experiência do cotidiano e, embora sua tese não tenha em mente os predicados do cinema, alinha-se com o esforço naturalista de Malick em construir seus traços invisíveis. "Trabalhar com o não-visto, é se dar conta de que vemos e de que, acima de tudo, não vemos; de que, na rotina, experimentamos frequentemente um estado de cegueira" (DIAS, 2010, p. 224)

Em Dias de paraíso, a sequência dos campos de trigo em chamas para expulsar uma praga de gafanhotos foi o motivo pelo qual, provavelmente, a Academia de Hollywood premiou o fotógrafo Néstor Almendros - o Oscar gosta de premiar valores de produção. E Almendros concorda que se pudesse usar refletores e rebatedores teria muito menos trabalho para filmar essas cenas. Havia muito fogo e o que o fotógrafo propõe é criar uma inversão questionando a luz em excesso que limita a visão, e a sombra refletida que cria espaços que se permite ver. Sua escolha por close-ups para intercalar a paisagem dominada pelo fogo ressalta o movimento das sombras, como almas no purgatório (uma vez que a queimada da fazenda significaria o fim do emprego de tantos trabalhadores que combatiam as chamas). Portanto, a sombra exerce um papel fundamental na claridade, ressaltando seu instante poético. "É na treva que vê melhor sua luz" (BACHELARD, 1994, p. 183). Estica-se um novo horizonte a cada vez que em ambivalência o visto e o não-visto cooperam para um olhar para além do quadro. "Olhar a sombra é conceber um mundo onde os caminhos seriam menos evidentes, as margens, sempre outras e o 
horizonte, vasto. É arriscar-se em uma visão do (in)comum que libera o olhar de suas fronteiras habituais" (DIAS, 2010, p. 232).

Notemos que sombra e luz cooperam para o quanto deseja-se ocultar e revelar na imagem. Cauquelin pontua que tal imagem não se pretende um território singular, mas volta-se ao acontecimento que solicita a sua presença. Embora os esforços de Malick, como vemos, empreendam um disfarce de sua narrativa ou ao menos procrastinar seu efeito de ação, é esta narrativa que habita o centro do quadro por maior que seja a força centrífuga que o diretor tenta impor ao olhar do espectador. A paisagem, portanto, apresenta-se em caráter retórico. "Está orientada para a persuasão, serve para convencer, ou ainda, como pretexto para desenvolvimentos, ela é cenário para um drama ou para a evocação de um mito" (CAUQUELIN, 2007, p. 49).

\subsection{O mito revelado}

Eis que a compreensão da imagem-cristal, por via de um processo do devaneio, passa por uma revelação de vicissitudes do estado aquoso da imagem. Se voltamos à ideia do orvalho ${ }^{53}$ recorremos à cristalinidade da imagem, cujas propriedades complexas reúnem também sua opacidade, sua densidade e sua infinitude cíclica. Ora, o orvalho difere-se da água que escorre do firmamento e enturva-se somando as impurezas do ar e do solo. No entanto, o orvalho não é entregue pelo universo suficientemente puro, necessitando à sua qualidade de ser-no-mundo um devir. Aqui, tonificamos o princípio de Heiddegger, no qual subentendemos uma caractereística relacional do homem com o mundo mediada por um aspecto transcendental que achata a distância entre essência e tanscendência. Esse devir do ser-no-mundo, que buscará enaltecer e tocar o fundo do seu ser orvalhoso só pode ser alcançado por esforço do sonhador. "Destila-o e cooba-o para que ele rejeite o que lhe resta de supérfluo, para que se torne germe puro, puramente germinativo" (BACHELARD, 1990, p. 258). O caráter imaginativo da evidência do orvalho se relaciona com as questões do invisível ou do não-visto. Cabe ao artista, qual

\footnotetext{
53 Tratamos acerca de sua metáfora no capítulo 2. Henry de Rochas fornecerá um conceito mais completo em La physique reformée la contenant la réfutation dês erreurs populaires et le triomphe des vérités philosophiques. Paris, 1648, p. 255-259.
} 
habilidoso construtor de sonhos, apontar os caminhos pelos quais se revelam tais imagens ocultadas. "O artista que pudesse extrair da planta esse orvalho celeste teria, diz um alquimista em sua vigorosa linguagem, um médium e uma ventosa capazes de atraírem para si todas as virtudes do simples" (BACHELARD, 1990, p. 259).

Se não podemos rastrear até onde o olho do espectador enxerga as proezas do artista em seus traços invisíveis (ao menos não é a isso que se propõe a presente reflexão), a dedução que permitimos é a de que a experiência do sensível caberá a cada pessoa assimilar em suas capacidades cognitivas, imaginativas e contemplativas. Quando falamos do espectador dos filmes do cineasta Terrence Malick - ou da fruição de cada um diante das imagens apresentadas - só podemos fazê-lo por meio de uma investigação das intenções evidenciadas técnica e poeticamente pela própria obra em questão. $\mathrm{O}$ efeito arrebatador ou desolador a que pode ser conferida tal experiência da purificação do orvalho não pode ou nem deve ser explicado. Ele, aliás, pode ou não estar presente no mesmo lugar. Cabe ao poeta - podemos aqui falar de Malick - servir de "guia metafísico", como sugere Bachelard, do espectador ávido por compreender ou identificar $o$ instante da poesia na obra de arte.

O poeta anima uma dialética mais sutil. Revela, ao mesmo tempo, no mesmo instante, a solidariedade da forma e da pessoa. Prova que a forma é uma pessoa e que a pessoa é uma forma. A poesia torna-se, assim, um instante da causa formal, um instante da potência pessoal. (BACHELARD, 1994, p. 189)

A revelação consiste, portanto, de uma experiência sensorial capaz de ser deduzida, imaginada e vivida por meio da relação onírica do espectador diante da imagem. Esse viés teopoético que exploramos no universo cinematográfico de Malick e que se fundamenta nos seu uso peculiar da linguagem cinematográfica, decorrente de uma estilização de movimentos de câmera e manipulação sonora, por exemplo, redundase no princípio do mito, onde encontramos seu modo de fabular. Podemos afirmar que a narrativa, ou melhor, a fabulação construída por Malick e deduzida a partir da imagem evoca Deus? O que dignifica essa compreensão do imaterial, do transcendente dentro da geometria dos planos de câmera? Uma possível conclusão decorre de que não devemos almejar as respostas objetivas, pois elas são inertes tal qual a representação de cartãopostal, ou à gratuita invocação espiritualista dos provérbios usados levianamente ou da já 
comentada literatura banal de pretensão a uma edificação. Bachelard nos lembraria, ao comentar as pinturas de Marc Chagall, que "o universo é digno de ser pintado". Por isso, ele seria belo. Para além do debate estético - que não é a função do texto original de Bachelard nem o nosso objetivo neste momento -, percebemos que o sentimento de serno-mundo não requer justificativas, mas justificação.

Partimos para uma nova metáfora, que inclui a força redentora. Ora, esta sina da justificação pressupõe uma mensagem de libertação ou liberação (o homem teria consigo o salvo-conduto para seguir sua jornada pacificada no-mundo, ou uma descrição das rupturas, abismos e contradições da existência humana, conforme compreende Kuschel mirando a característica teopoética da fábula contemporânea. "Justificação não é um produto dos próprios esforços e conquistas, mas sim um dom da graça de Deus" (KUSCHEL, 1999, p. 224). Quando olhamos para os personagens de Malick inseridos em um $m y t h o s^{54}$, não olhamos para a justiça (de suas transgressões, por exemplo). A ação da natureza, do acaso ou de Deus não necessita do agir humano. Quando deliberadamente Marina (Olga Kurylencko) vinga-se de seu marido, Neil (Ben Affleck) entregando-se a um momento de prazer com um desconhecido em Amor pleno, sua atitude não se desenovela por imbricamentos dramatúrgicos melodramáticos de guerra conjugal, ciúmes ou mesmo jogo de traições, mas em paisagens onde a mão da personagem brinca de esconder o sol da imensidão celeste. O julgamento divino traz a reboque consigo um gesto de perdão que dispensa dramaturgia, não sem antes permitir que se pese sob Marina uma outra paisagem: as nuvens carregadas e do concreto estéril debaixo de seus pés ao deixar o hotel onde extravasara sua revolta pelo desamor a que Neil a relegara.

$A$ árvore da vida, por outro lado, expressa a justificação por meio de uma representação de fé. Mr. O'Brien (Brad Pitt) deixa a mera postura religiosa, conservadora e capitalista com a qual educa seus filhos para admitir ao final seu fracasso. A família segue unida até o fim, independemente da "conversão" de Mr. O'Brien. Ou seja, a atitude do personagem não vai influenciar o desenlace da narrativa, uma vez que a justificação dos personagens de Malick está imbuída de certo espírito de predestinação. Ora, em $O$ novo mundo, Pocahontas (Q'orianka Kilcher), por mais que abandone sua cultura, suas

\footnotetext{
54 "A fábula (mythos) e a narativa são, primordialmente, o que reúne num todo a ação humana" (CAUQUELIN, 2007, p. 52)
} 
vestes e seu amor por Smith (Colin Farrell), se reconecta com a natureza mesmo diante do castelo que passa a ser sua nova morada com John Rolfe (Christian Bale); Terra de ninguém resumirá a aventura criminosa do jovem casal a um tom de fábula em que o espectador se abstrai do complexo anti-heróico de Bonnie \& Clyde para um tratado acerca da frustação da vontade humana e do cumprimento do querer divino.

A experiência permanente de insondabilidade e estranheza da realidade humana e a nostalgia, ainda remanescente, pelo dia profetizado; a desilusão diante da situação humana, mas também o sonho indestrutível quando a noite chega; a condição vã dos esforços humanos, mas também a persistência nas tentativas. (KUSCHEL, 1999, p. 215)

Reconhecemos o sentido do cinema de Terrence Malick nas polaridades: céu e terra; sonho e realidade; mole e duro; noite e dia; altura e profundidade; silêncio e ruído; sagrado e profano; natureza e graça; visível e invisível. É nessa disjunção constituidora da imagem audiovisual ou no "arruinamento do esquema sensório-motor" (DELEUZE, 2010, p. 303) em que vislumbramos a composição do mito. O cinema de Malick passa, assim, portanto, por todos os valores até então já pesquisados em sua obra: existencialismo, evangelismo, espiritualidade, contemplação, poesia e consternação. $\mathrm{O}$ lugar onde chegamos, aqui, no entanto, nos aponta para um estado de poesia com aspirações teopoéticas. A paisagem delimita o lugar do ser, o convida, o inclui em sua totalidade. Devemos considerar a poética dos seres, de onde escorre pelas tangentes de sua insondabilidade, o mito revelado. "Quem vê a beleza divina num cacho de vaga-lume com certeza viu a glória de Deus" (ALVES, 2001, p. 34). 


\section{Considerações finais}

Este texto, originalmente, no planejamento da escrita da dissertação, acompanhava um subtítulo: "acerca das trevas". Em seguida, optamos por apresentar um último exercício teopoético que compreendesse a noção sacralizada - por uma ótica judaico-cristã - dos polos ambivalentes de céu e inferno a partir de um diálogo do cinema de Terrence Malick com o do brasileiro José Mojica Marins. Partimos da hipótese de que se poderia compreender teopoeticamente as menções de Malick à insondabilidade do céu e de Mojica à inescrutabilidade do mundo, usando como fio condutor as figuras angelicais e os seres nefastos representados em cada contexto, mas também considerando o aparato industrial-tecnológico por trás dos filmes do norte-americano e a espontaneidade genial e mambembe que guiara Mojica. Afinal, entendemos que os resultados mais importantes de se pontuar na presente conclusão circunscrevam-se dentro da busca pela teopoética. Invocaremos Mojica em momento oportuno.

Malick, embora colecione ainda poucos filmes em seu currículo para cinco décadas incompletas de carreira (são apenas sete longas concluídos até 2015), tem sido um diretor muito pesquisado. Sua obra, evidentemente, como mostramos, desperta curiosidades em diversos sentidos. Os filmes do cineasta receberam olhares acerca de sua relação com o western e a configuração historiográfica dos Estados Unidos; também foi analisado pelo viés mais latente que os filmes apresentam: a pulsão filosófica, que encontra sobretudo em Heidegger embasamento para a construção do debate existencialista que permeia a filmografia. Há também obras de fôlego que vão tratar do aspecto poético e idílico do cinema de Malick, em suas referências à natureza e às paisagens. Em uma ocorrência mais tímida, encontramos alguns trabalhos (artigos

principalmente) que propõem debater as questões espirituais e religiosas ou mesmo teológicas presentes nas temáticas abordadas por Malick.

Depois de nos inspirarmos nesta vastidão interdisciplinar que permeia o conjunto de produção cinematográfica de Malick, nos interessamos em transitar por todas essas possibilidades. No entanto, abriu-se para nós um caminho (até onde temos conhecimento) 
inédito para a análise do peculiar cinema do diretor norte-americano. A esta expedição, demos o nome de teopoética. Afinal, nela encontramos o conceito que abarcaria a complexidade dos aspectos divinos traduzidos por meio de uma determinada dicção estética da qual o diretor se utiliza. Podemos ainda debater se em suas narrativas ele procura uma representação do Deus cristão, ou intenta aprofundar-se na questão heideggeriana do ser-no-mundo. Por meio da fenomenologia do devaneio - à qual embarcamos guiados pela metafísica de Bachelard - pudemos evitar os caminhos teóricos que redundariam a pesquisa em visitas às categorias mais exploradas pela crítica de cinema e pelo empenho acadêmico de investigação para trabalharmos uma noção ainda muito pouco explorada na esfera da arte, que é a tepoética. Ou seja, buscamos tratar, em uma esfera de linguagem, de questões caras à teologia, mas que se desprendem dela quando o interessem maior de investigação recai em uma análise por vias da imagem cinematográfica.

Ao percebermos uma possibilidade de elaborações de instantes teopoéticos em um cinema declaradamente espiritualista como o do cineasta norte-americano, nos ressentimos com uma dívida à pujança secular a que o próprio Kuschel se refere ao apontar um mundo inescrutável na literatura de Kafka. Ou, quando anjos falam, como nos remete a figura de Mrs. O'Brien (Jessica Chastain) em A árvore da vida, cuja voz se pronuncia por meio de melodias, sussurradas em voz over, não devemos invocar também os demônios? Reconhecemos que há uma leitura binária influenciada pela própria ordem da teologia cristã ao nos referirmos a anjo e demônio; a céu e inferno; a bem e mal. Lúcifer nada mais era senão um anjo de luz. Em sua etmologia hebraica, Satanás não corresponde necessariamente ao imaginário convencional do ser nefasto de coloração avermelhada, chifres, dentes afiados e um tridente em mãos, mas tem em uma de suas suas definições nominais um sinônimo para "adversário". Versando sobre nossa experiência com a teopoética, poderíamos partir de uma suposição de que o discurso sobre Deus colocado em termos de linguagem nos permite observar a potência das relações entre o homem e o divino por meio de uma poética de características teocêntricas. Mas este debate não compreende apenas uma determinada beleza que Malick busca a todo custo em seu estilo, resvalando inclusive em maneirismos quanto à representação da glória com seus abusivos feixos de luz, por exemplo. Há no discurso 
espiritualista do cineasta um contraste muito salutar para reivindicar a humanidade de seus personagens e de seus relacionamentos inter e intrapessoais.

Em Terra de ninguém, temos a virginal Holly (Sissy Spacek), cujo nome em tradução para o português denota "santa". A santidade relacionada com a virgindade é um aspecto caro à cultura sacra. Holly não se comporta como a Virgem Maria, a Santa Mãe bíblica, afinal falta-lhe justamente o predicado maternal. Holly, contudo, carrega consigo uma utopia ingênua da Terra Prometida. Na tradução brasileira fica claro que seu destino aponta para uma terra estéril, de onde não haverá espaço para os assomos da maternidade. É de “ninguém”. Semelhante aproximação é possível fazer por meio do título original do filme: Badlands. Em português: "terras más". Seu futuro com Kit (Martin Sheen) se entrevê romântico, embora intransigente, e desenha-se como uma bela paisagem mesmo na habitação amaldiçoada de Montana.

A imagem de santidade, não há como ignorar, alimenta não apenas o lirismo idílico e espiritualista de uma teopoética. Um julgamento sem reflexão da função da teopoética nos redundaria em cometer o erro ao qual Kuschel nos previne: "Deus se mostra um mau princípio estilístico sempre que rebaixado a objeto de uma literatura edificante banal, a um pretexto para conciliações apressadas e para gratuidades" (KUSCHEL, 1999, p. 214). Em uma arriscada aproximação com o cinema do brasileiro José Mojica Marins, concluiremos nosso raciocínio que persegue o instante teopoético. Esse instante não está, entendemos, apenas no excesso de luz, na manipulação tecnológica altamente profissional amparada por uma estrutura industrial hollywoodiana como a de Malick. Mojica, por produzir um cinema de natureza de horror e ainda por esta atividade ser desenvolvida com toda a precariedade tecnológica do Brasil dos anos 60, propõe um cenário altamente sacralizado para tratar de um mundo niilista, no qual a fé está falida: a religiosidade do povoado do interior paulista em que se passa $A$ meia-noite levarei sua alma (1964) ganha as primeiras fissuras estéticas radicais na fotografia pretoe-branca, logo preenchida pela figura funesta de Josefel Zanatas, um agente funerário amargurado pela traição de sua noiva e pela morte dos pais apelidado pela vizinhança de Zé do Caixão.

O discurso sobre Deus vem expressar uma crise espiritual da consciência moderna, na medida em que 
esta percebe as fantasias de auto-endeusamente. Em contraste com os sonhos de onipotência e com as fantasias de endeusamento inerentes ao homem na modernidade, os escritores voltam o olhar para a criaturalidade elementar do ser humano. (KUSCHEL, 1999, p. 217)

Criatura e criação sempre sentaram-se à mesa em meio a uma dissensão profunda. Adão e Eva foram afastados do paraíso após os dias de bródio no palácio das bemaventuranças do Éden; o monstro de Victor Frankenstein carregou o nome de seu criador e, por maior ódio que nutrisse do cientista enlouquecido, subentendia um desejo de inclusão; Malick ao criar seus anjos convoca o pessimismo da humanidade e embrutece a relação afável da voz devocional e do canto pastoril centralizando na tela o desgaste das ações humanas (fogo, morte, destruição, desamor, desamparo, traição...). Mojica talvez opere dentro desse mesmo código em À meia-noite levarei a sua alma (1964). Analisemos:

Zé do Caixão adere à religiosidade na dicção do protagonista acerca de sua crença. Ora, Mojica o coloca como um personagem nietzscheniano. Zé não acredita em Deus nem no Diabo. Seu compromisso é com o homem, sendo ele próprio o representante máximo da espécie, com o objetivo único de encontrar uma mulher igualmente perfeita para copular - a dominação do macho sobre a fêmea aqui colocada revela outra aproximação com a representação das relações entre o masculino e o feminino em Malick.

Mas Mojica constrói sua fábula - falando especificamente da aparição do personagem em À meia-noite levaria sua alma - em um cenário totalmente sacralizado. De capa preta, cartola e unhas compridas, a comunidade o teme justamente por seu estereótipo diabólico, reforçado também por sua descrença na mitologia do ataque das almas penadas no Dia de Finados. Enquanto o vilarejo fica recluso na noite de 2 de novembro, Zé sai à rua sem temer. Quando, então, é surpreendido justamente pelo fator sobrenatural. À meia-noite, os mortos saem de suas tumbas e reivindicam sua alma. Mojica, portanto, abandona a figura nietzscheniana - não que ele tivesse qualquer compromisso filosófico - para admitir a existência de um mundo espiritual regido por forças de Deus e do Diabo. 
Da mesma forma que Mojica em $\dot{A}$ meia-noite, Malick admite questões morais e filosóficas e insinua um caráter espiritual em Terra de ninguém e em Dias de Paraíso, os quais não apresentam um discurso direto acerca de Deus como nos demais filmes, contudo, apresentam seres de natureza angelical, caso de Holly. A personagem feminina retratada como ser de pureza terá na tradição do cinema de horror uma função muito incisiva - não raro torna-se a heroína dos filmes slasher dos anos 70 e 80 ou é o objeto de cobiça, como do Conde Drácula. Mojica busca a mulher superior mas que será uma escrava, Malick coloca a mulher como esse ser que habita na glória divinal em uma situação de desamparo. Linda (Linda Manz) e Abby (Brooke Adams), em Dias de paraiso, acompanham Bill (Richard Gere) por todos os caminhos. Abby, sua esposa, se passa por seu irmão e casa-se com o Fazendeiro (Sam Shepard) para atender à cobiça de Bill por uma herança vindoura. E ao se apaixonar pelo seu novo marido, ela sela um destino trágico a ambos os homens. Sem eles, embora aprisionada, ela se liberta para um futuro desolador. Marina (Olga Kurylencko), em Amor pleno, reage de forma semelhante com Neil (Ben Affleck), em suas idas e vindas de amor e ódio, de união e separação com seu amante. Neil trai Marina e segue sua vida. Marina faz o mesmo contra ele e se encolhe, e recorre à igreja como se o pecado pesasse apenas sobre ela. As mulheres de Malick são figuras angelicais, bem como as mulheres do horror. O choque sobre o qual o homem nefasto se impõe sobre elas ganha tons mais explícitos em Mojica, embora não se diferencie da opressão maligna desempenhada pelos personagens masculinos de Malick.

O que nos traz de volta a inquirir como a teologia nos permite abordar esse fenômeno, que passa pelo espiritual, pelo religioso, contudo não se aprofunda na doutrina, uma vez que a confronta ou a ignora. Não há mais Deus no horizonte da fé dos personagens de Malick. Padre Quintana (Javier Bardem), em Amor pleno, peregrina por casas desocupadas e vizinhanças inóspitas em busca de oferecer consolo. Encontra o vazio, fantasmas habitantes de uma crença esvaziada, mas que por meio de um caráter estilístico de narração fílmica oferece uma aspiração celestial e também telúrica. E, de repente, manifesta-se um deus diante dos olhos incrédulos de Josefel em Mojica. Aliás, vários. Esses seres sobrenaturais o dominam e o contradizem. Além disso, por mais que habitem a profundeza da terra, as almas penadas sobrevoam em seu Dia de Finados, a pequena cidade, arrebatando como anjos aos que ousem afrontá-las. 
É preciso reconhecer na teologia a noite em que ela se encontra e a noite para a qual ela aponta e avança. É preciso reconhecer na dicção teológica que ela não possui aquilo de que fala, nem o lugar ao qual crê conduzir as pessoas. É árida a linguagem - a linguagem em que se nota a ameaça que pousa sobre a teologia, e em que se sente que ela ainda não 'chegou' a seu objetivo (SCHWANDT apud KUSCHEL, 1999, p. 225)

Na fé do cético; na descrença do que crê apresenta-se a contradição da teologia. Eis a conquista da teopoética. 


\section{Referências bibliográficas}

ALVES, Rubem. Coisas da alma, da vida, da alegria. São Paulo: Paulus, 2001.

ALVES, Rubem. Theopoetics: longing and liberation. In: GETZ, I. E COSTA, R. (oprgs.). Struggles for solidarity, PP. 159-171. Philadelphia: Fortress Press, 1991.

AUMONT, Jacques. O olho interminável (cinema e pintura). São Paulo: Cosac \& Naify, 2011.

AUMONT, Jacques e MARIE, Michel. Dicionário teórico e crítico do cinema. Campinas: Papirus, 2003.

BACHELARD, Gaston. A água e os sonhos. São Paulo: Martins Fontes, 1989.

BACHELARD, Gaston. A poética do devaneio. São Paulo: Martins Fontes, 1988.

BACHELARD, Gaston. A terra e os devaneios da vontade. São Paulo: Martins Fontes, 1991.

BACHELARD, Gaston. A terra e os devaneios do repouso. São Paulo: Martins Fontes, 1990.

BACHELARD, Gaston. O ar e os sonhos. São Paulo: Martins Fontes, 1990.

BACHELARD, Gaston. O Direito de Sonhar. Rio de Janeiro: Bertrand Brasil, 1994.

BARNETT, Christopher B. Spirit(uality) in the films of Terrence Malick. Omaha: Journal of Religion \& Film: Vol. 17: ISS. 1, Article 33, Abril, 2013.

BARROS, Manoel de. Poesia completa. São Paulo, Leya, 2010.

BAZIN, Andre. O que é o cinema?. São Paulo: Cosac \& Naif, 2014.

Bíblia - Tradução Ecumênica. São Paulo: Edições Loyola, 1994.

BIDENT, Christophe. Le geste théâtral de Roland Barthes. Paris: Ed. Hermann, 2012.

BISKIND, Peter. The runaway genius. Los Angeles: Vanity Fair: n. 460, dez., 1998.

BISSON, Frédéric. L'arbre du monde et le Dieu invisible. Caen (França): Eclipses Revue de Cinema: n. 54, Junho, 2014.

BLOCH, Ernst. O princípio da esperança. Rio de Janeiro: UERJ/Contraponto, 2005

BOSI, Alfredo. O ser e o tempo da poesia. São Paulo: Cultrix, Ed. Universidade de São Paulo, 1977. 
CASTRO, Gustavo. Comunicação e transcendência. São Paulo: Annablume, 2013.

CAUQUELIN, Anne. A invenção da paisagem. São Paulo: Martins Fontes, 2007.

CHAKALI, Saad. La beuté Du geste. Caen (França): Eclipses Revue de Cinema: n. 54, Junho, 2014.

CHION, Michel. The voice in cinema. New York: Columbia University Press, 1999.

DARWIN, Charles. A origem das espécies. São Paulo: Martin Claret, 2014.

DELEUZE, Gilles. A imagem-tempo (Cinema 2). São Paulo: Editora Brasiliense, 1990.

DIAS, Karina. Entre visão e invisão: paisagem. Brasília: Programa de Pós-Graduação em Arte, Universidade de Brasília, 2010.

DURAND, Gilbert. L'imaginaire: essai sur les sciences ET La philosophie de l'image. Paris: Hatier, 1994.

FERREIRA, Agripina Encarnación. Dicionário de imagens, símbolos, mitos, termos e conceitos bachelardianos. Londrina: Eduel, 2008.

FURTER, Pierre. Dialética da esperança: uma interpretação do pensamento utópico de Ernst Bloch. São Paulo: Paz e Terra, 1974.

GUIDO, Laurent. De l'Or Du Rhin au Nouveau Monde: Terrence Malick et lês rythmes Du romantisme pastoral américain. Paris (França): Décadrages: Cinéma, à travers champs: n. 11, Novembro, 2007.

HEIDEGGER, Martin. Ser e tempo. Trad. Márcia de Sá Cavalcante Schuback. Petrópolis: Vozes, 2006.

HEIDEGGER, Martin. Poetry, Language, Thought. Nova York: Harper \& Row, 1971.

JUNG, C. G. Psicologia e religião oriental. Petrópolis: Vozes, 2011.

KEEFE-PERRY, L. B. C. Theopoetics: process and perspective. Omaha: Journal of Religion \& Film, Vol 17, ISS. 1, Article 33, abril, 2013.

KUSCHEL, Karl-Josef. Os escritores e as escrituras. Retratos teológicos-literários. Trad. Paulo Astor Soethe et alii. São Paulo: Loyola, 1999.

LEÃO, Emmanuel Carneiro. Aprendendo a pensar I - O pensamento na filosofia moderna e na crise da religião. Edição aumentada e revisada. Rio de Janeiro: Daimon Editora, 2008.

LEITHART, Peter J. Shining glory: theological reflections on Terrenc Malick's The tree of life. Eugene: Cascade Books, 2013. 
MAHER JR., Paul. One big soul: an oral history of Terrence Malick. San Bernardino: autor, 2014.

MARCONDES, Ciro Inácio. Limite: o poema em filme. Dissertação de mestrado. Brasília: Universidade de Brasília, 2008.

MCLEOAD, James, Narrative vistas: subversive voice-over in Terrence Malick. Sidney: Philament Sense \& Sensation, n. 14, Agosto, 2009.

MICHAELS, Lloyd. Contemporary film directores: Terrence Malick. Urbana/Chicago: University of Illinois Press, 2009.

MURPHY, John. Paradise lost: the films of Terrence Malick. GodSpy: 26 fev. 2006. Disponível em: < http://oldarchive.godspy.com/reviews/Paradise-Lost-The-Films-ofTerrence-Malick-by-John-Murphy.cfm.html >. Acesso em 21 mar. 2015.

PATTERSON, Hannah (org.). The cinema of Terrence Malick: poetics visions of America. New York: Columbia University Press, 2007.

PATTERSON, John. The new world: a misunderstood masterpiece?. 10 dez. 2009. Disponível em: < http://www.theguardian.com/film/2009/dec/10/the-new-world-terrencemalick $>$. Acesso em: 12 jan. 2013.

PAZ, Octavio. O arco e a lira. São Paulo: Cosac \& Naif, 2014.

PIERCE, Charles Sanders. Como tornar claras as nossas ideias e A fixação da crença; in: Semiótica e filosofia. São Paulo: Editora Cultrix, 2010.

RILKE, Rainer M. Letters Of Rainer Maria Rilke Vol. II: 1910-1926. New York: Norton, 1947.

RYBIN, Steven. Terrence Malick and the thought of film. Maryland: Lexington Books, 2012.

SANTIAGO, Silviano. Nas malhas da letra. Rio de Janeiro: Rocco, 2002.

SANTOS, Joe G. Por uma teologia da imagem em movimento: uma troca de olhar com o cinema a partir da obra de Andrei Tarkovski no horizonte da teologia de Paul Tillich. Tese de doutorado. São Leopoldo: Escola Superior de Teologia, 2006.

SAVERNINI, Érika. Índices de um cinema de poesia: Pier Paolo Pasolini, Luis Buñuel e Krysztof Kielowski. Belo Horizonte: Editora UFMG, 2004.

TARKOVSKI, Andrei. Esculpir o tempo. $3^{\text {a }}$. Edição. São Paulo: Martins Fontes, 2010.

TUCKER, Thomas Deane e KENDALL, Stuart. Terrence Malick: film and philosophy. New York: Bloomsbury, 2011. 
VASCONCELOS, Anna Lisbôa. Catástrofe íntima: o apocalipse como desconstrução do indivíduo. Dissertação de mestrado. Barcelona: Universitat Pompeu Fabra, 2014.

WILDER, Amos Niven. Theopoetic: theology and the religious imagination. Philadelphia: Fortress Press, 1976.

XAVIER, Ismail (org.). A experiência do cinema. Rio de Janeiro: Edições Graal/Embrafilmes, 1983. 


\section{Referências filmográficas}

A ÁRVORE da vida. Direção: Terrence Malick. Fotografia: Emmanuel Lubezki. EUA: Cottonwood Pictures, 2011.35mm (139 min), NTSC, color. Título original: The tree of life.

A ÁRVORE dos tamancos, de Ermanno Olmi. Direção Ermanno Olmi. Fotografia: Ermanno Olmi. Itália: Ital-Noleggio Cinematográfico, 1978. DVD (186 min), NSTC, color. Título original: L’albero degli zoccoli.

À MEIA-NOITE levarei sua alma. Direção: José Mojica Marins. Fotografia: Giogio Attili. Brasil: Indústria Cinematográfica Apolo, 1964. DVD (84 min), p\&b.

ALÉM da Linha Vermelha. Direção: Terrence Malick. Fotografia: John Toll. EUA: Fox 2000 Pictures, 1998. DVD (170 min), NSTC, color. Título original: The thin red line.

AMOR Pleno. Direção: Terrence Malick. Fotografia: Emmanuel Lubezki. EUA: Redbud Pictures, 2012. 35mm (112 min), NSTC, color. Título original: To the wonder.

DIAS de Paraíso. Direção: Terrence Malick. Fotografia: Néstor Almendros. EUA: Paramount Pictures, 1978. DVD (94 min), NSTC, color. Título original: Days of heaven. a.k.a: Cinzas no paraíso.

LIMITE. Direção: Mário Peixoto. Fotografia: Edgar Brasil. Brasil: Cinédia, 1931. DVD (114 min), p\&b.

LUZ de Inverno. Direção: Ingmar Bergman. Fotografia: Sven Nykvist. Suécia: Svensk Filmindustri (SF), 1963. DVD (81 min), p\&b. Título original: Nattvardsgästerna.

O NOVO Mundo. Direção: Terrence Malick. Fotografia: Emmanuel Lubezki. EUA: New Line Cinema, 2005. 35mm (135 min), NSTC, color. Título original: The new world.

O SACRIFÍCIO. Direção: Andrei Tarkovsky. Fotografia: Sven Nykvist. Suécia/Reino Unido/França: Svenska Filminstitutet (SFI), 1986. DVD (142 min), NSTC, color. Título original: Offret.

TERRA de Ninguém. Direção: Terrence Malick. Fotografia: Tak Fujimoto, Stevan Larner e Brian Probyn. EUA: Warner Bros., 1973. 35mm (94 min), NSTC, color. Título original: Badlands. 


\section{Anexo}

Alguns frames cinematográficos que serviram como ponto de partida de análise e fundamentaram muitos dos nossos devaneios. Um exercício do instante.

\section{Terra de ninguém}

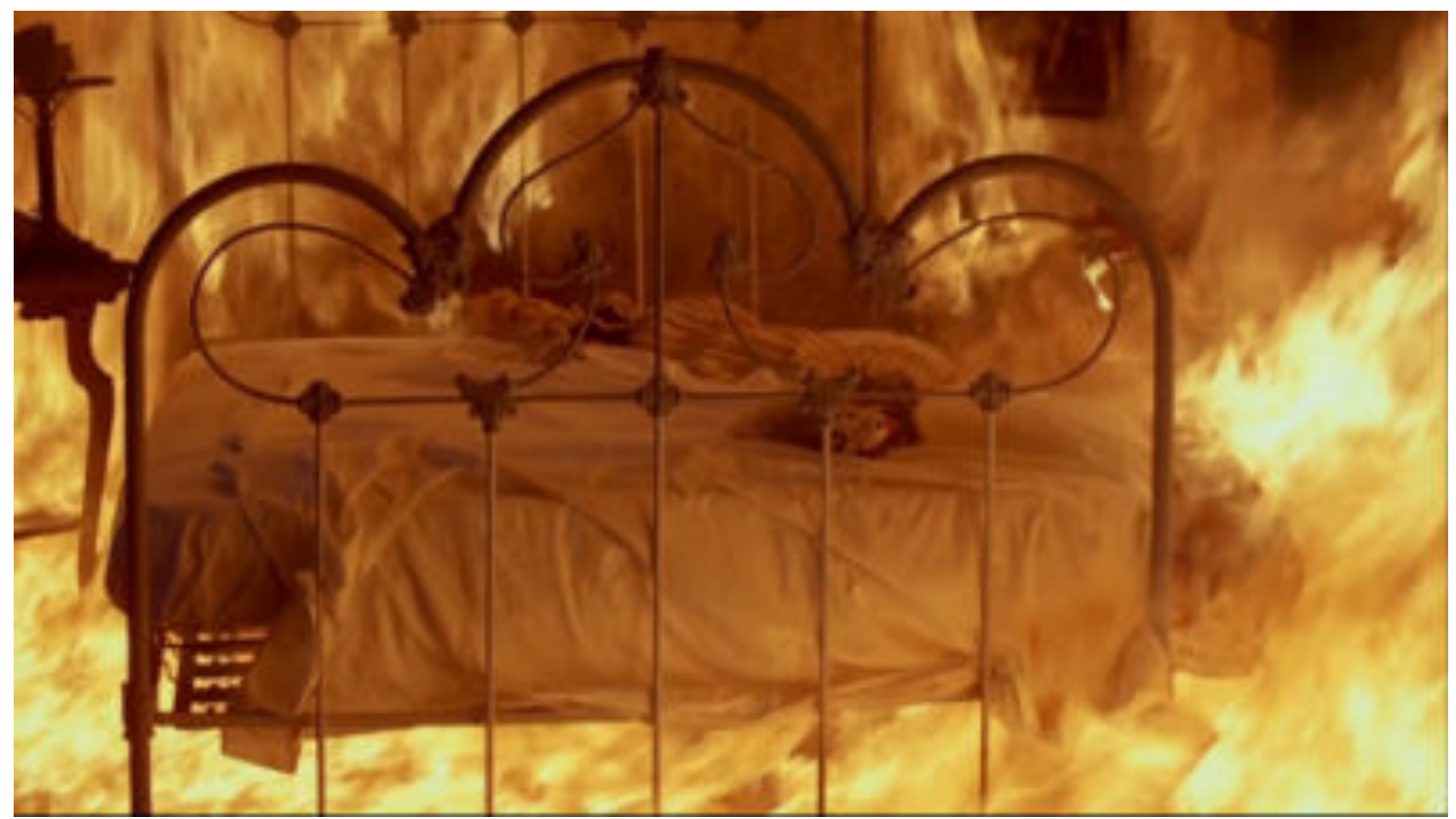

Fogo ateado na casa do pai de Holly após ter sido assassinado: destruição ao som de canto sacro

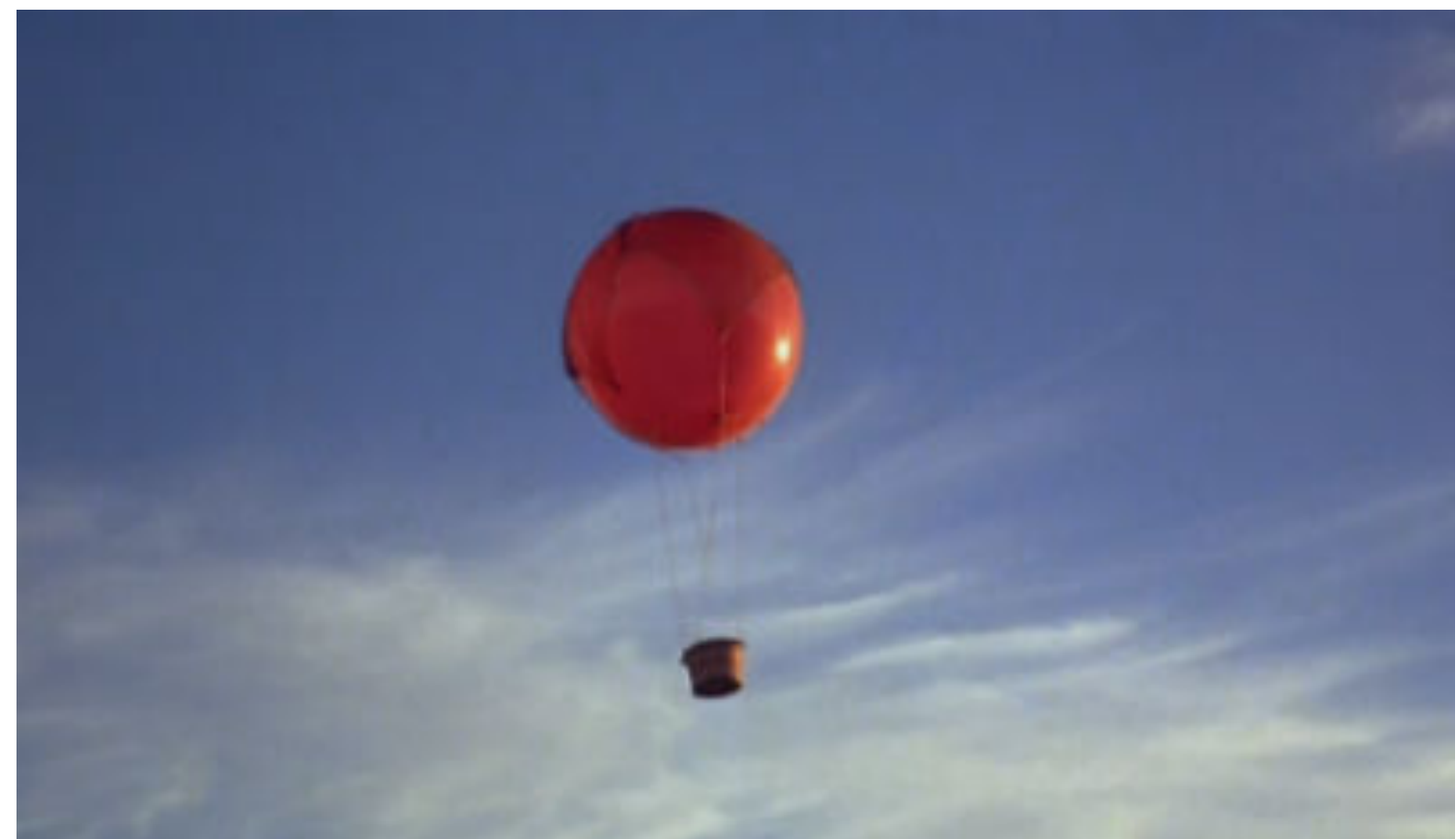

Balão lançado ao ar por Kit: um gesto ao céu e uma paisagem ascensorial 


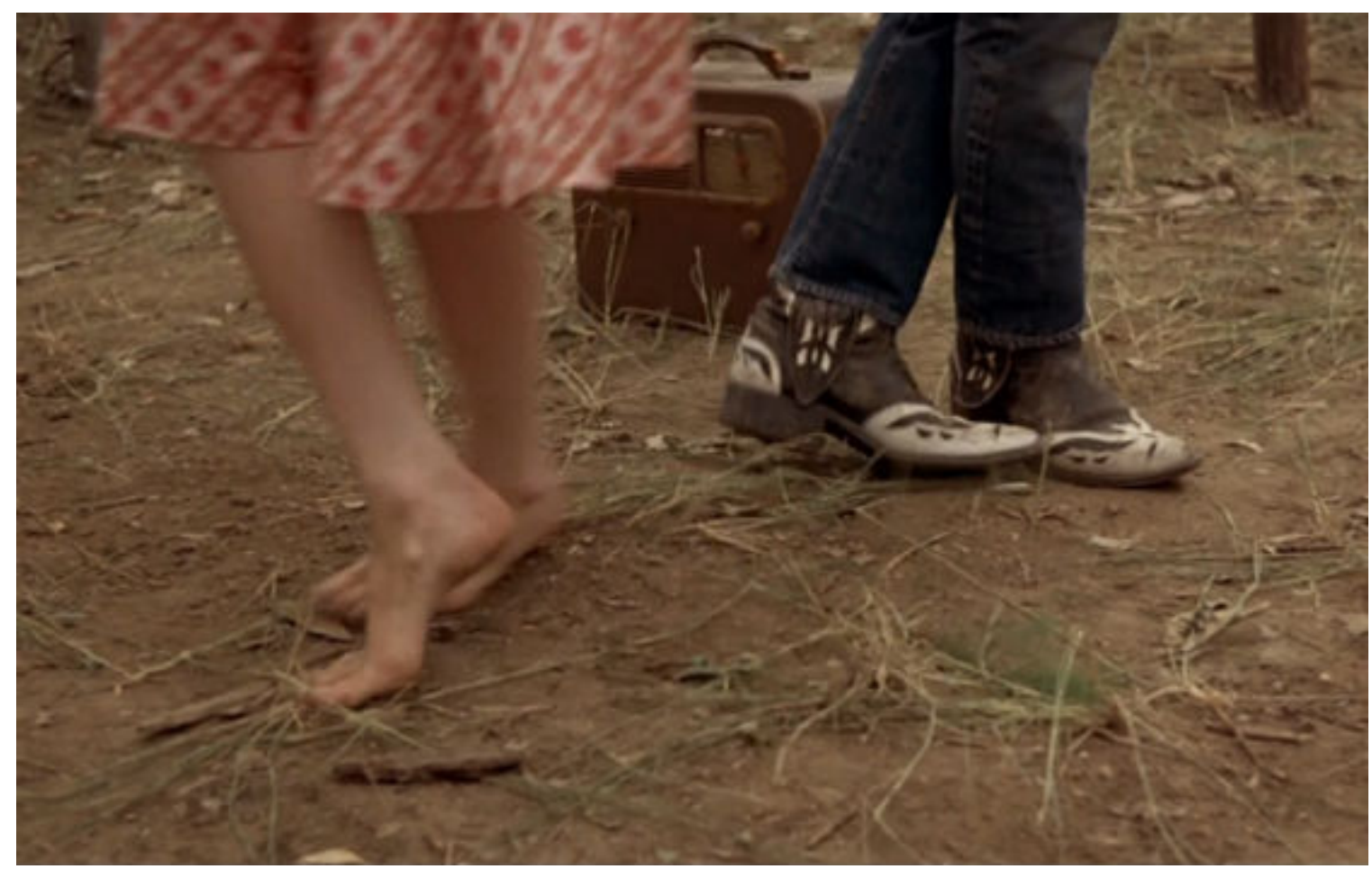

Pés de Holly e de Kit dançando no refúgio passageiro do casal: momento de brincadeira

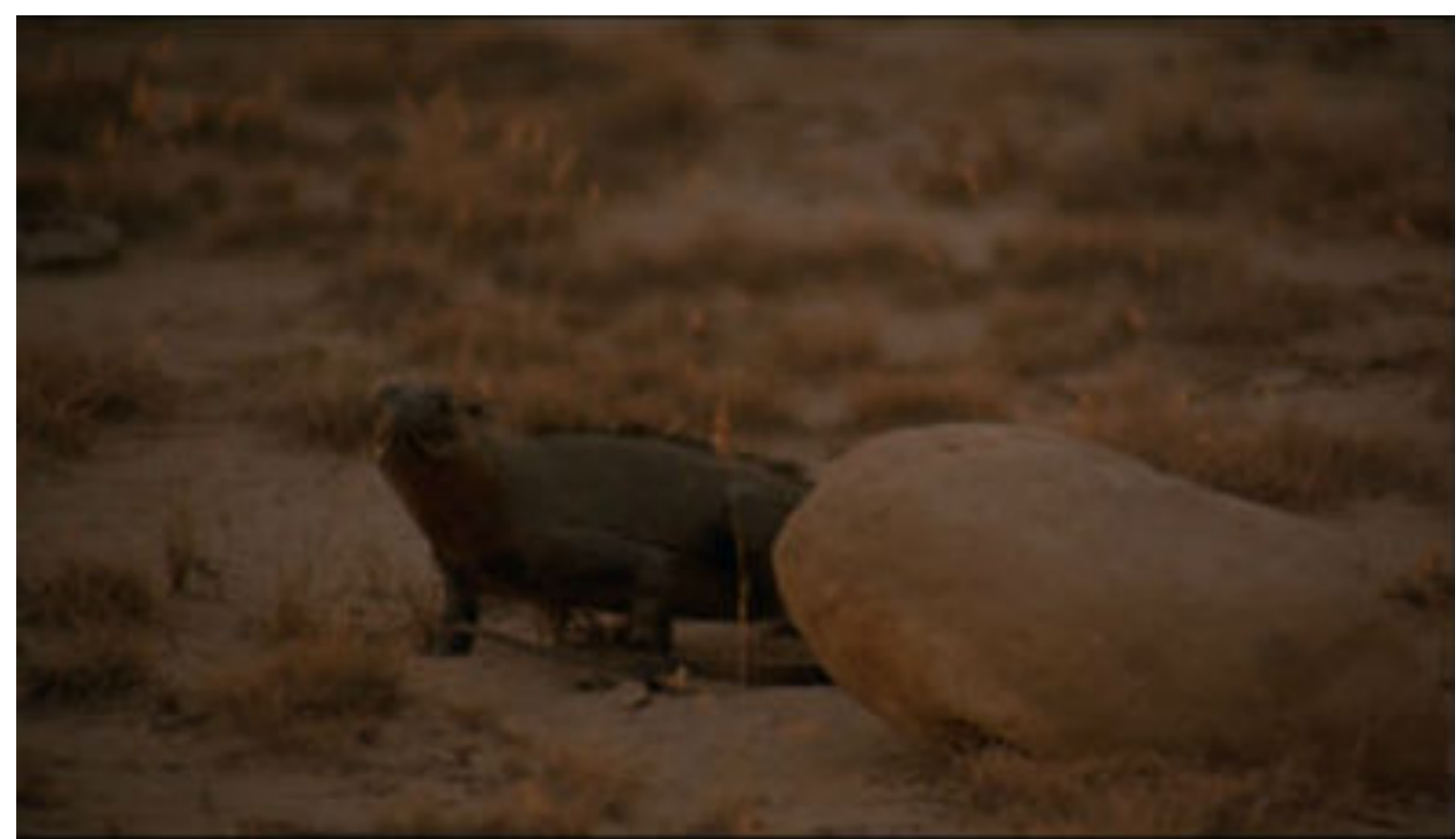

Lagarto em meio à terra árida pela qual passam Kit e Holly para chega às badlands de Montana 


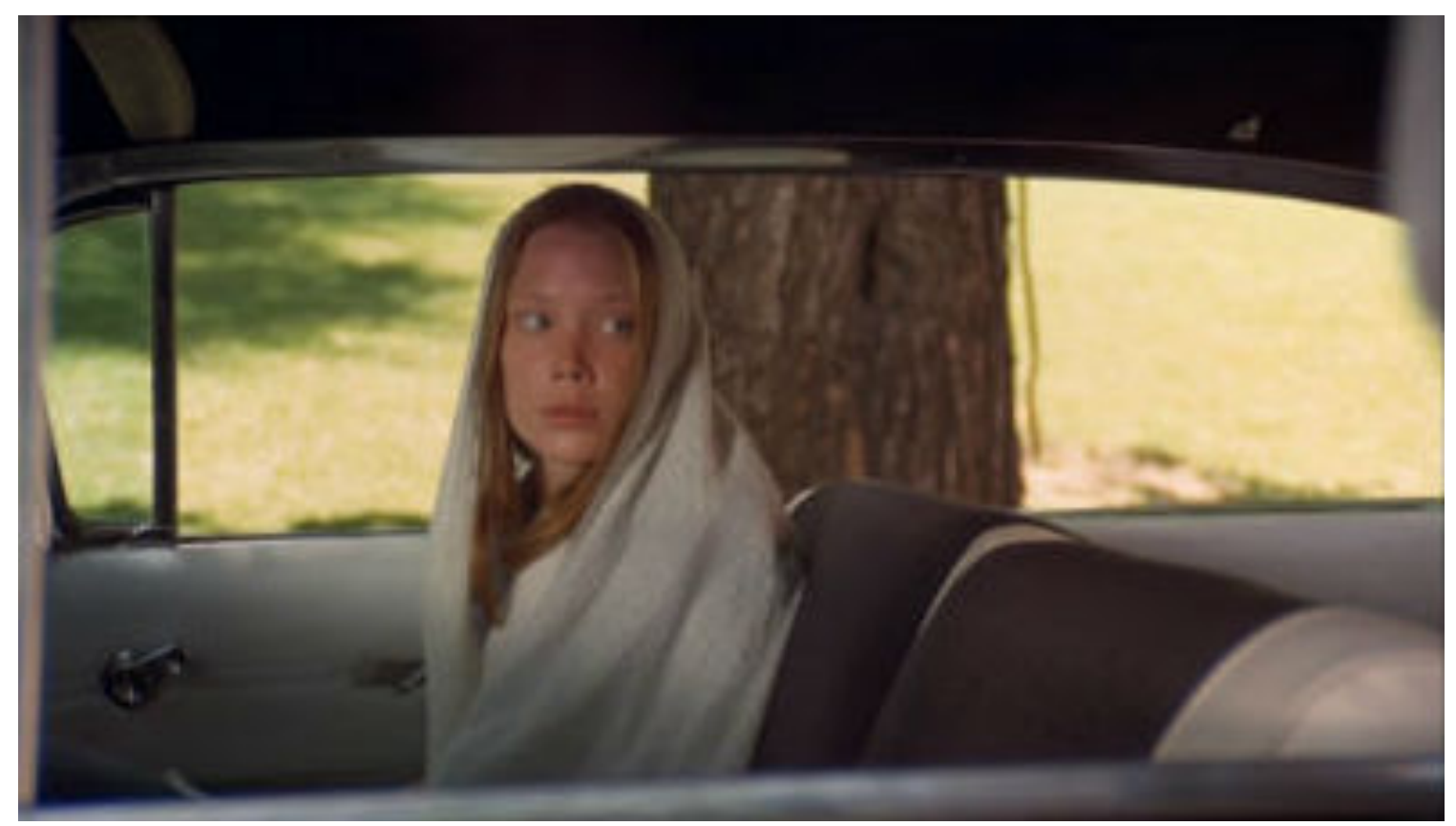

Holly com lençol recobrindo a cabeça e o corpo após deixarem a casa onde faziam reféns: a Virgem

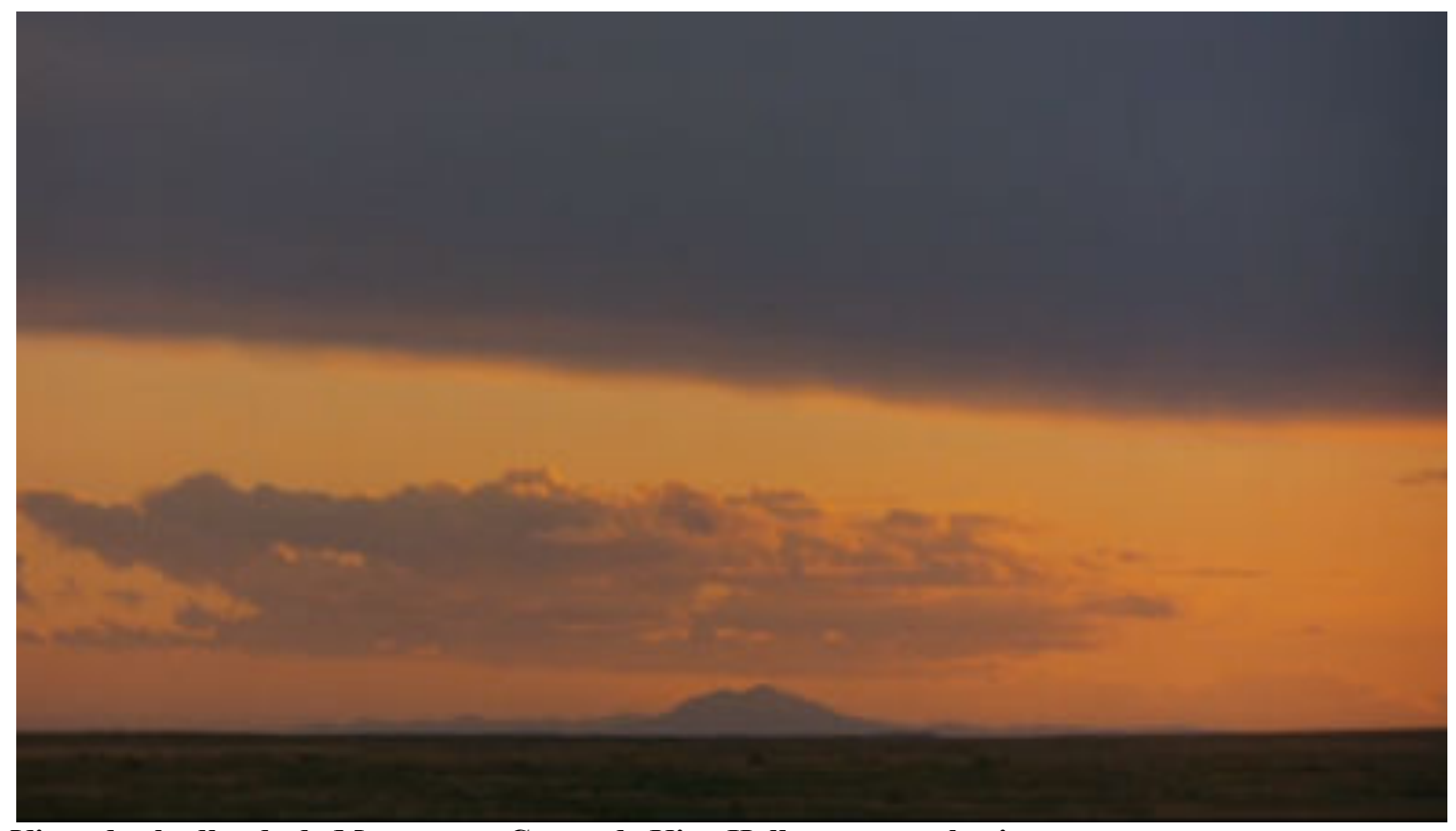

Visão das badlands de Montana: a Canaã de Kit e Holly se põe ao horizonte 


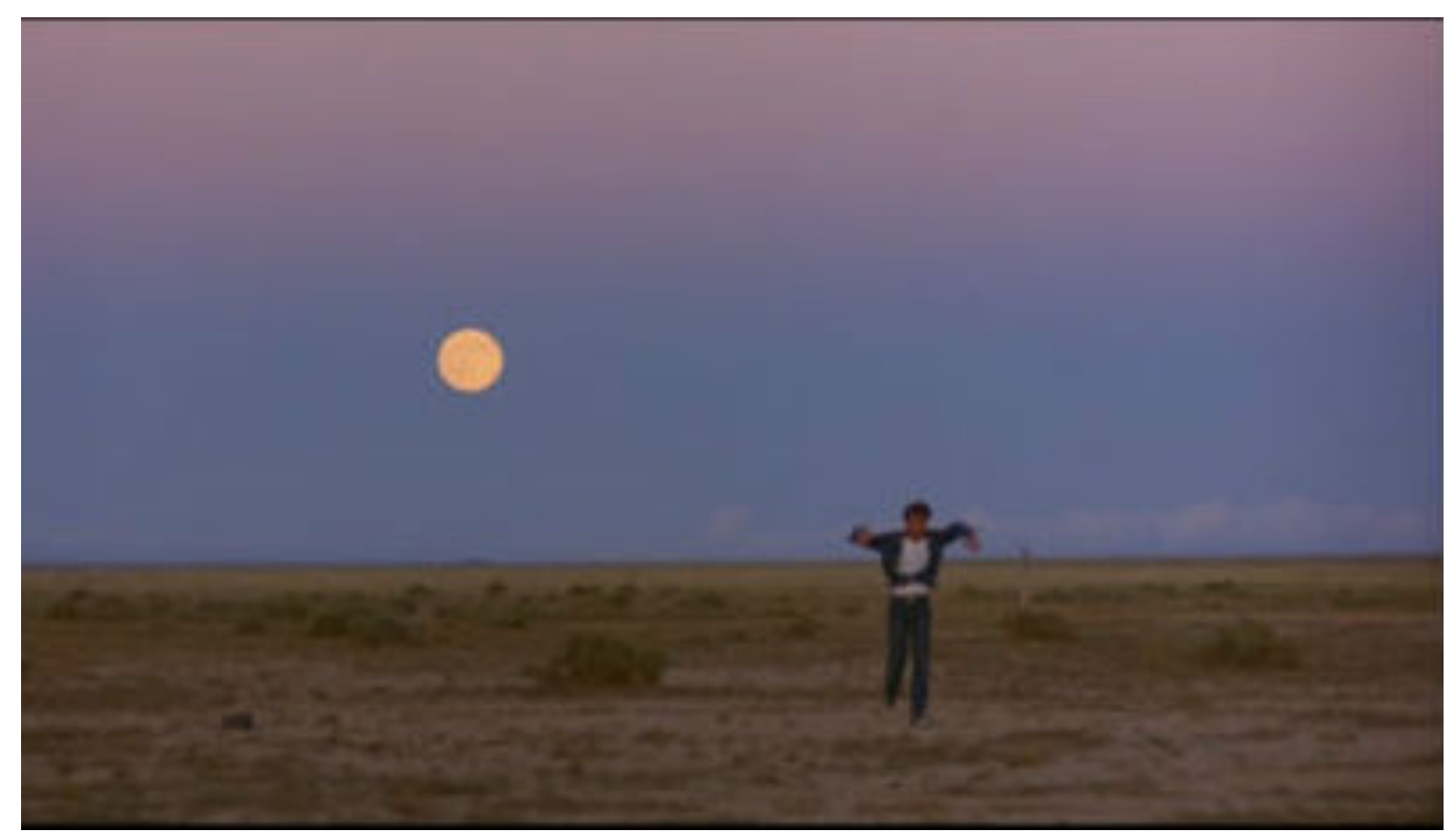

Kit com sua espingarda: câmera o acompanha mais à terra do que ao céu

\section{Dias de paraíso}

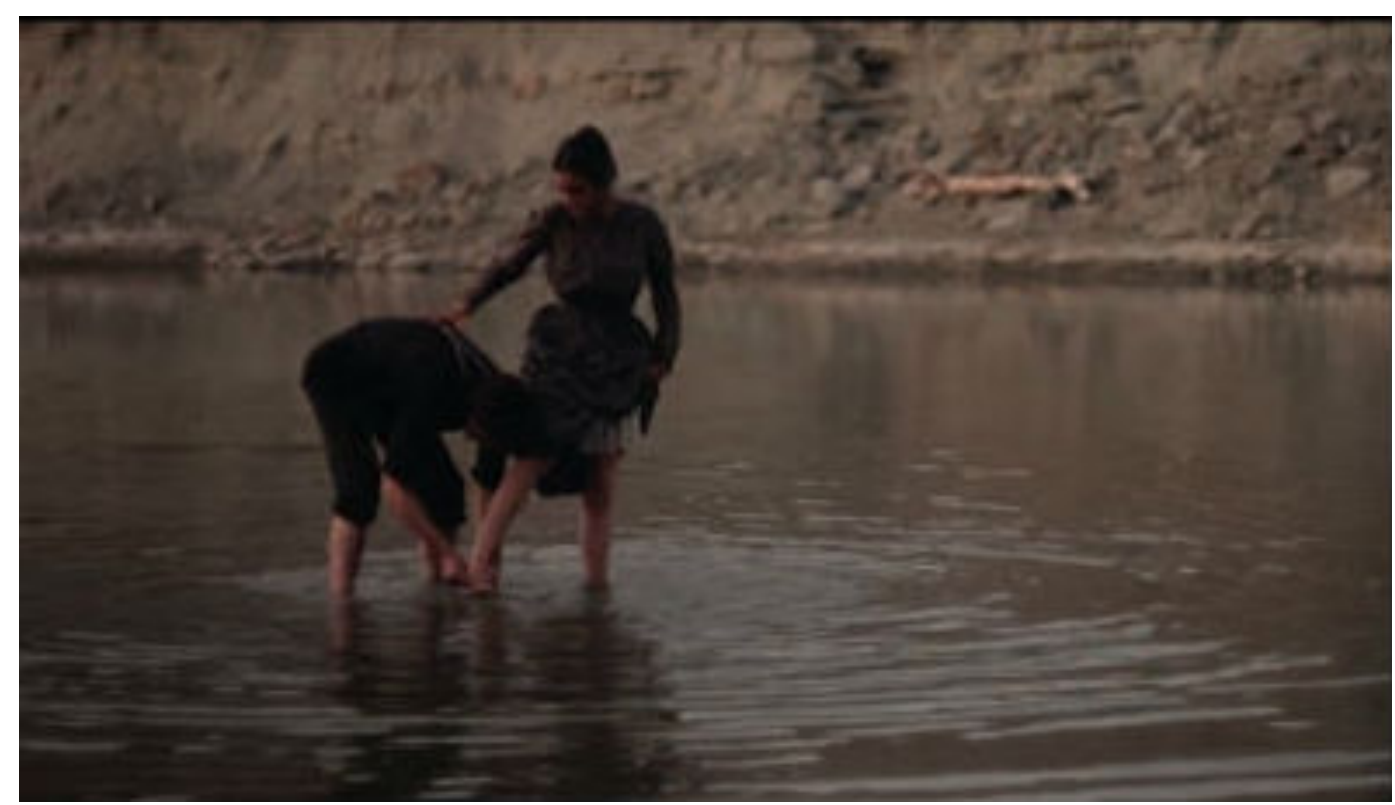

Bill lava os pés de Abby no rio: gesto semelhante ao de Cristo em relação aos discípulos 


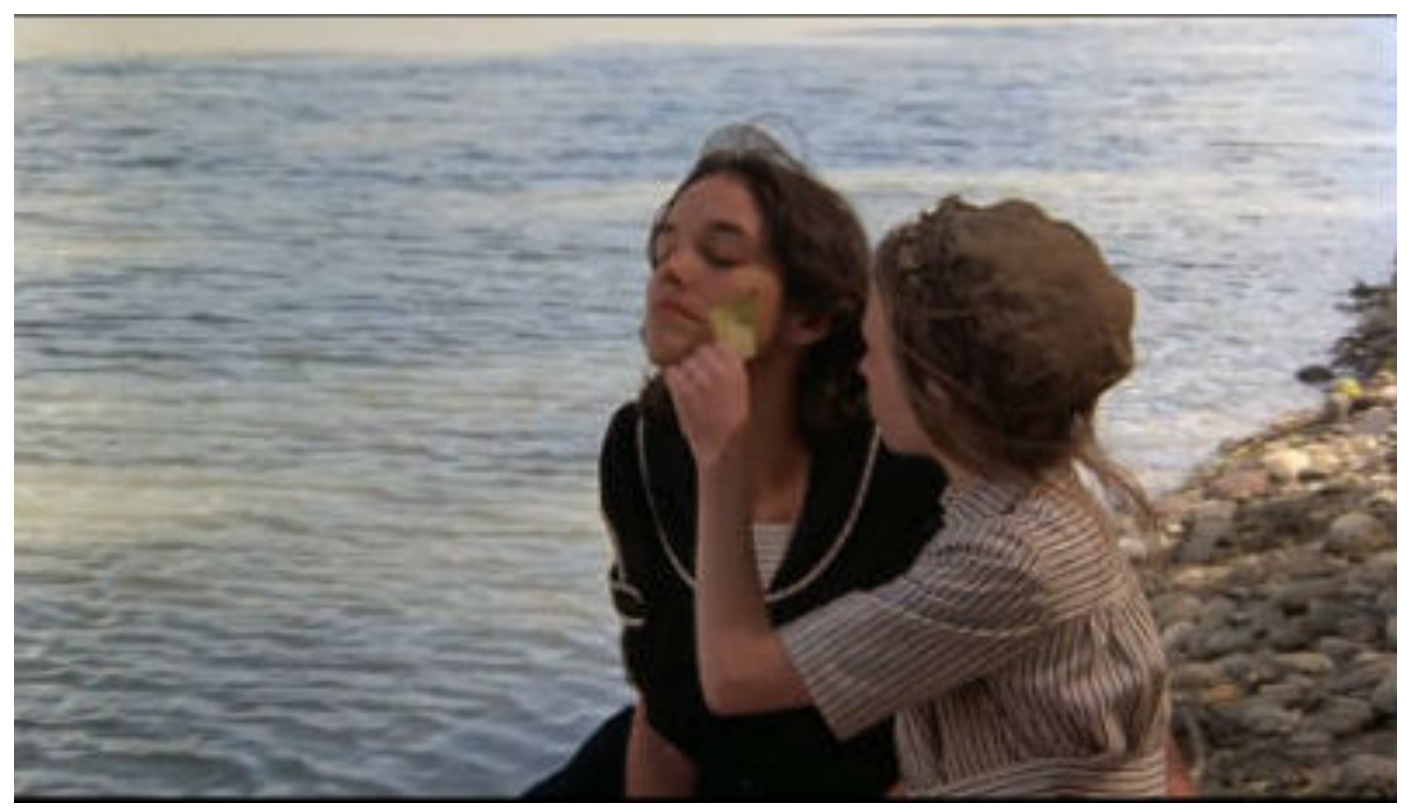

Abby brinca com Linda à beira do rio: o toque mediado pela natureza (uma folha)

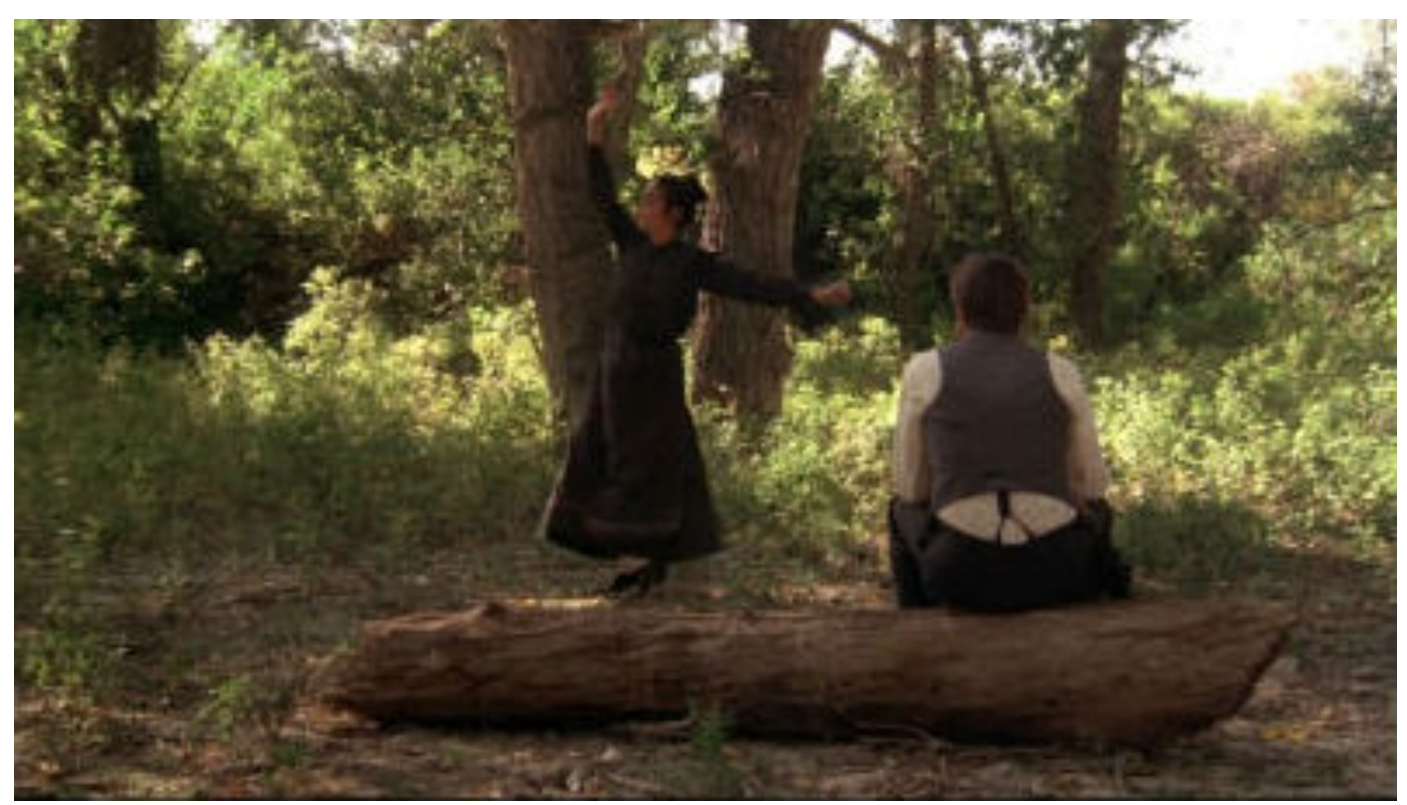

Abby exibe-se para o Fazendeiro: aprendera a dançar com as bailarinas de Baker Hall 


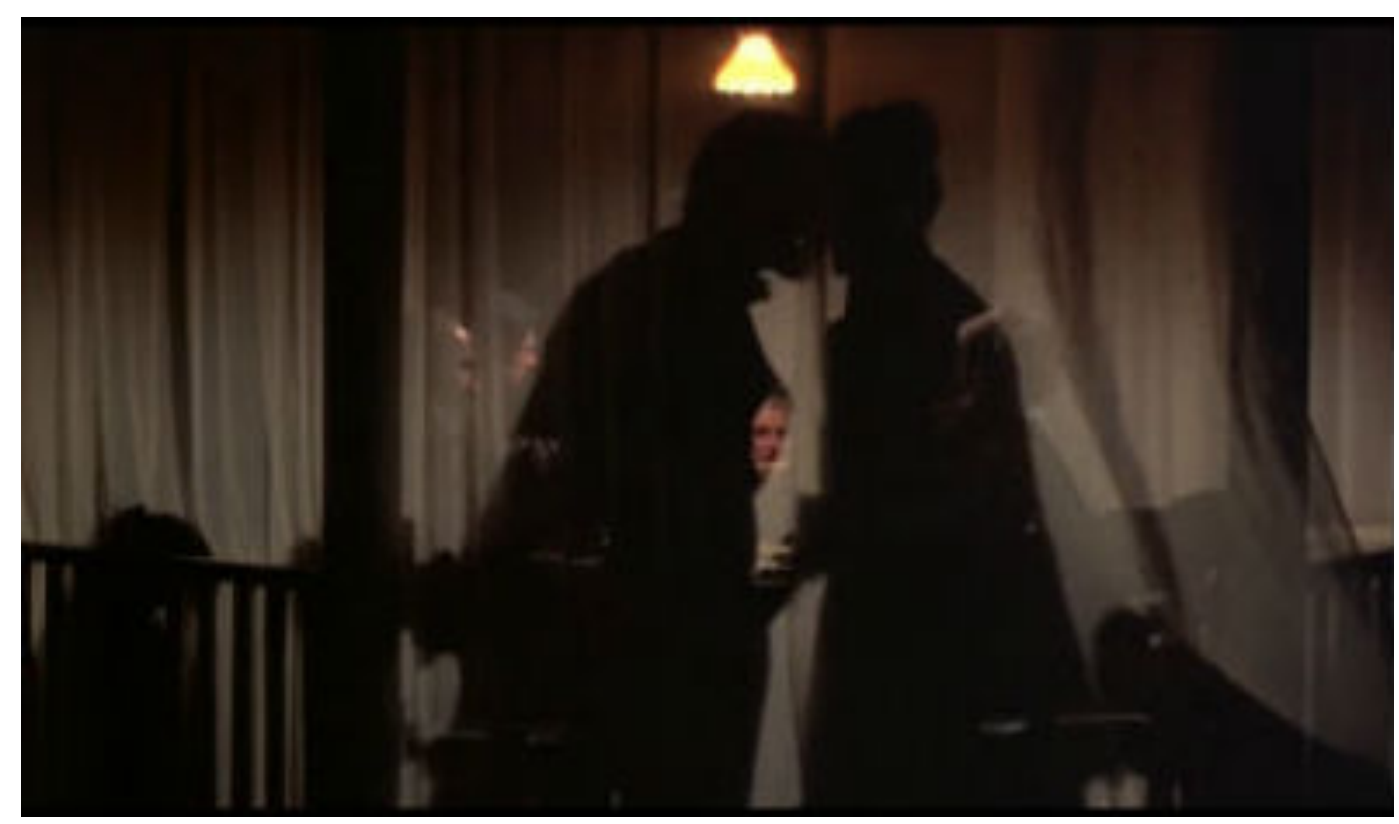

Silhueta dos “irmãos" Bill e Abby vista da perspectiva do Fazendeiro

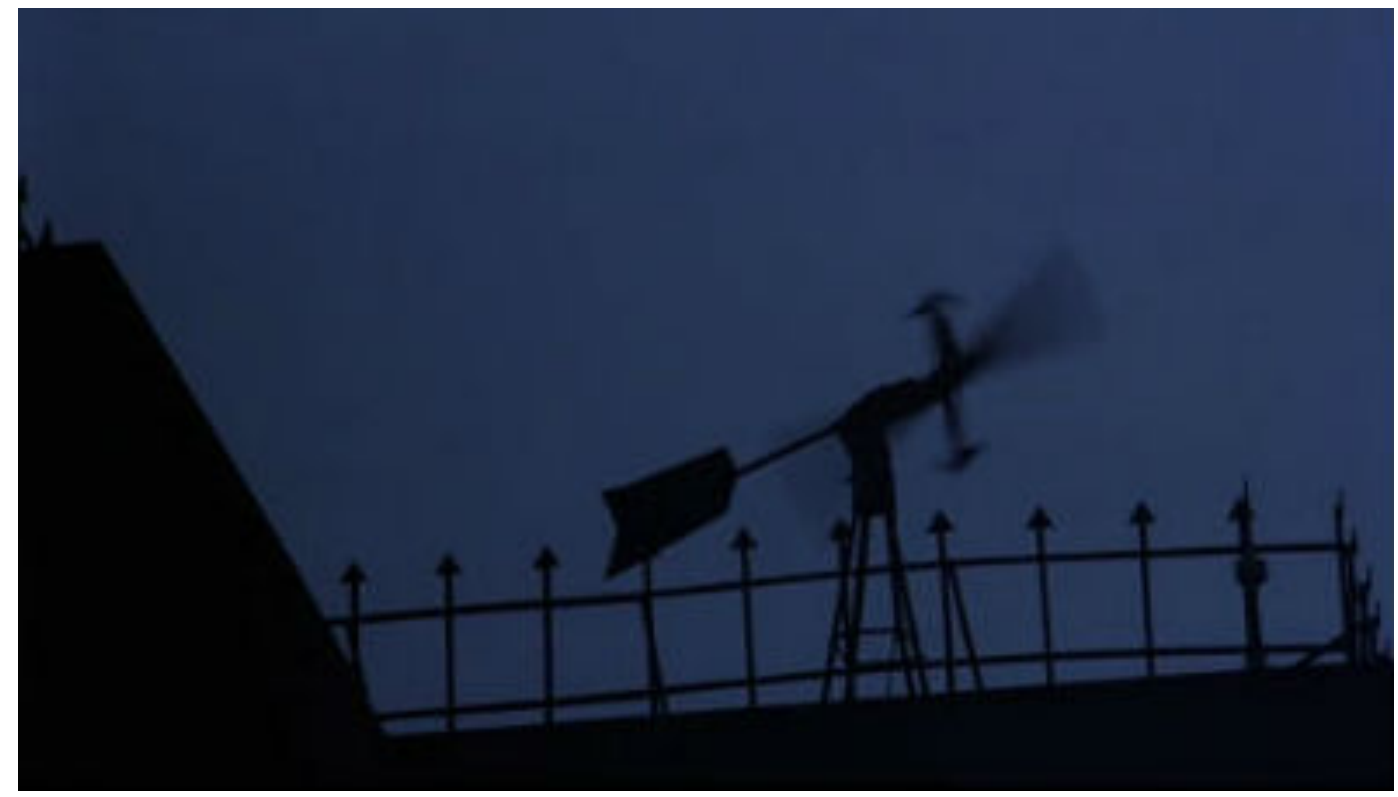

Catavento roda ante o crepúsculo e às vésperas da praga dos gafanhotos 


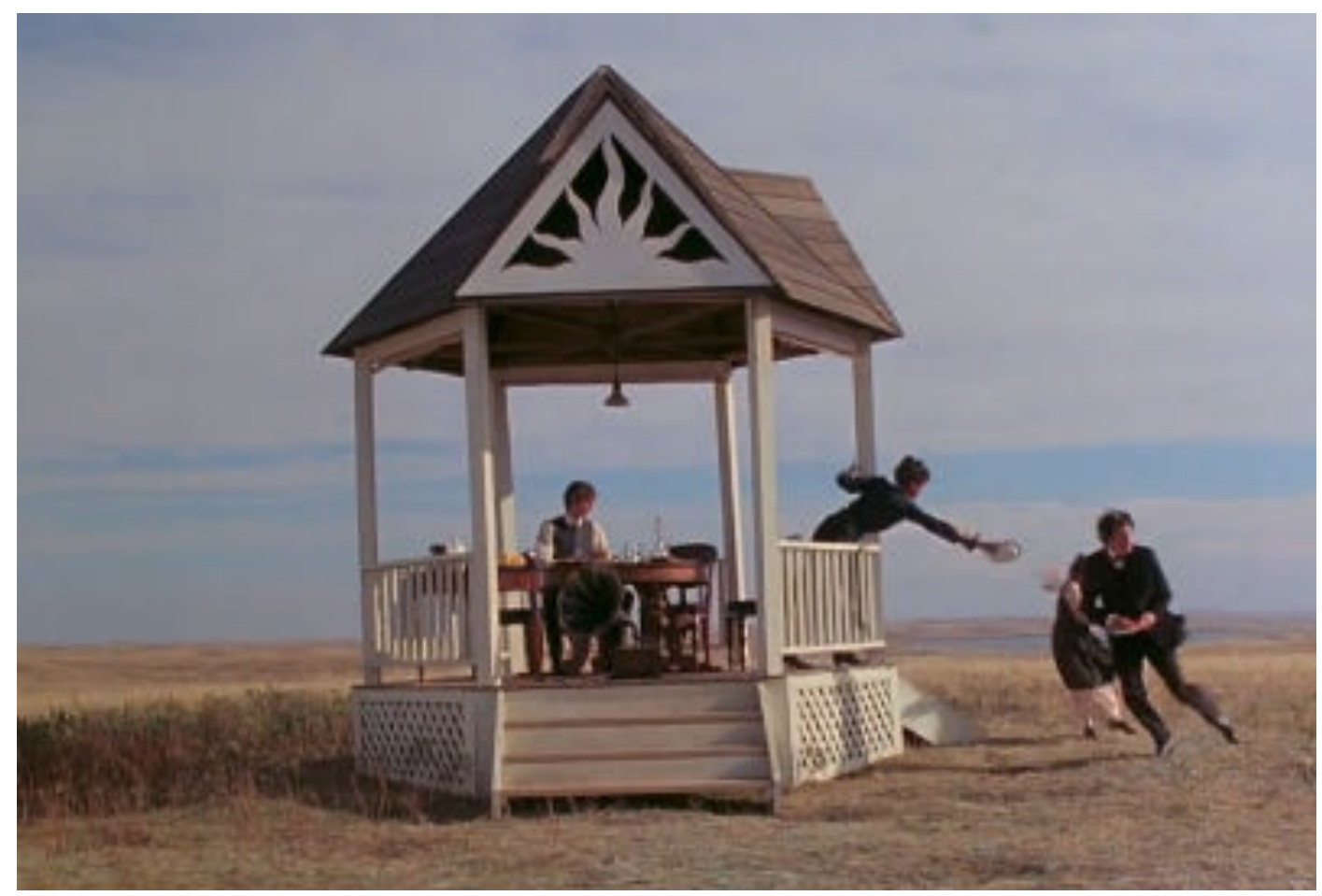

Lanche em família com Abby, Linda e Bill fazendo guerra de comida; o Fazendeiro observa

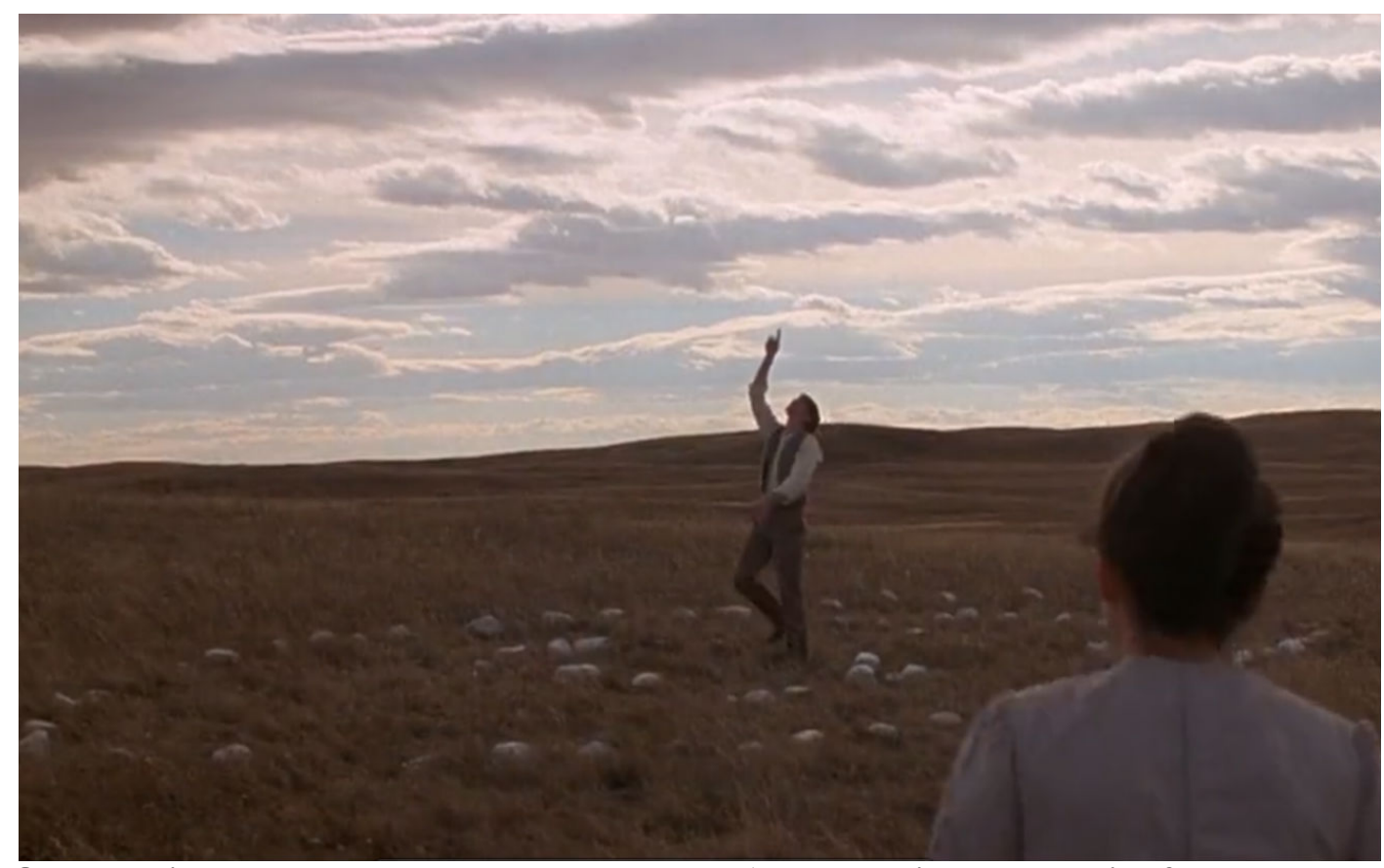

O Fazendeiro aponta para o alto, mostrando para Abby o caminho que o avião fará 


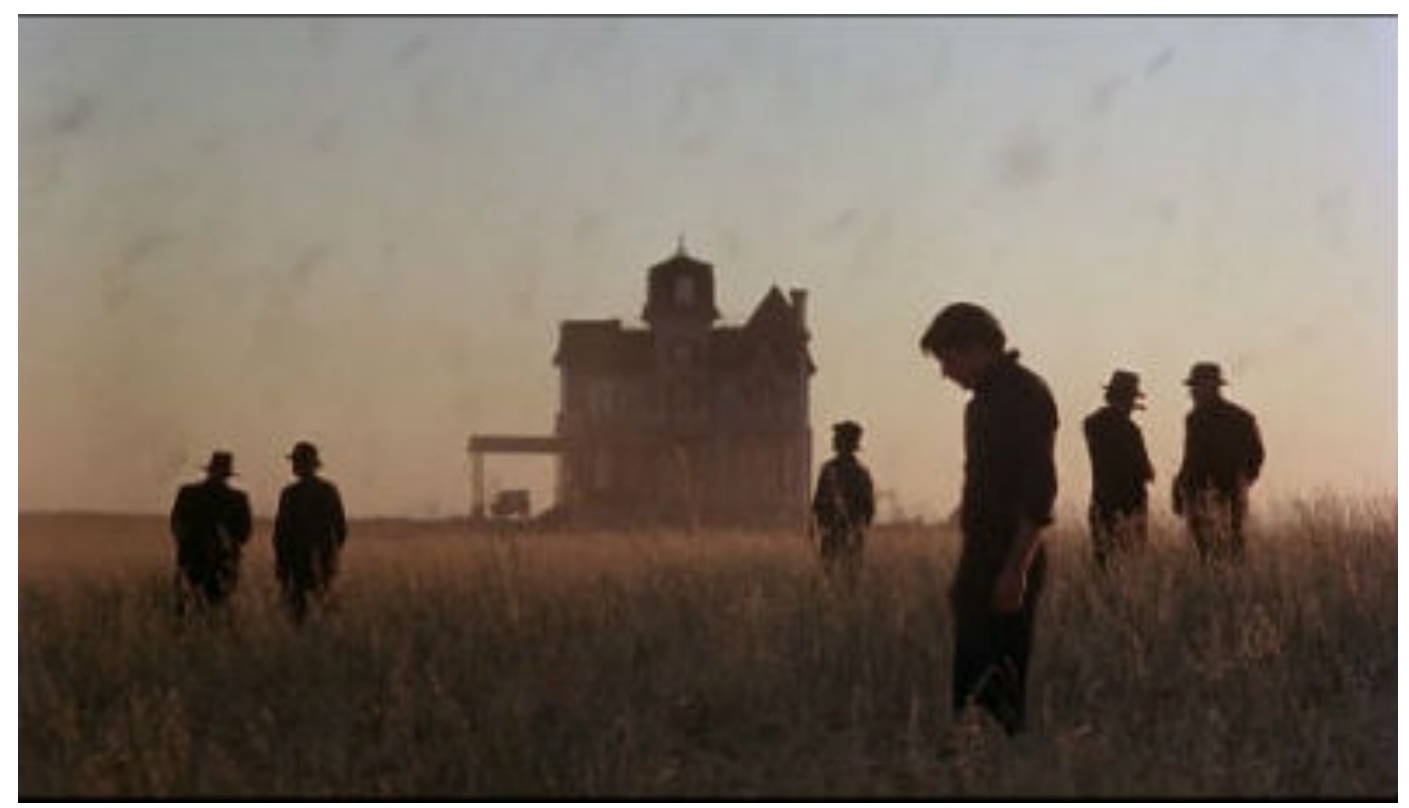

Bill em primeiro plano e a casa do Fazendeiro ao fundo: chove gafanhotos

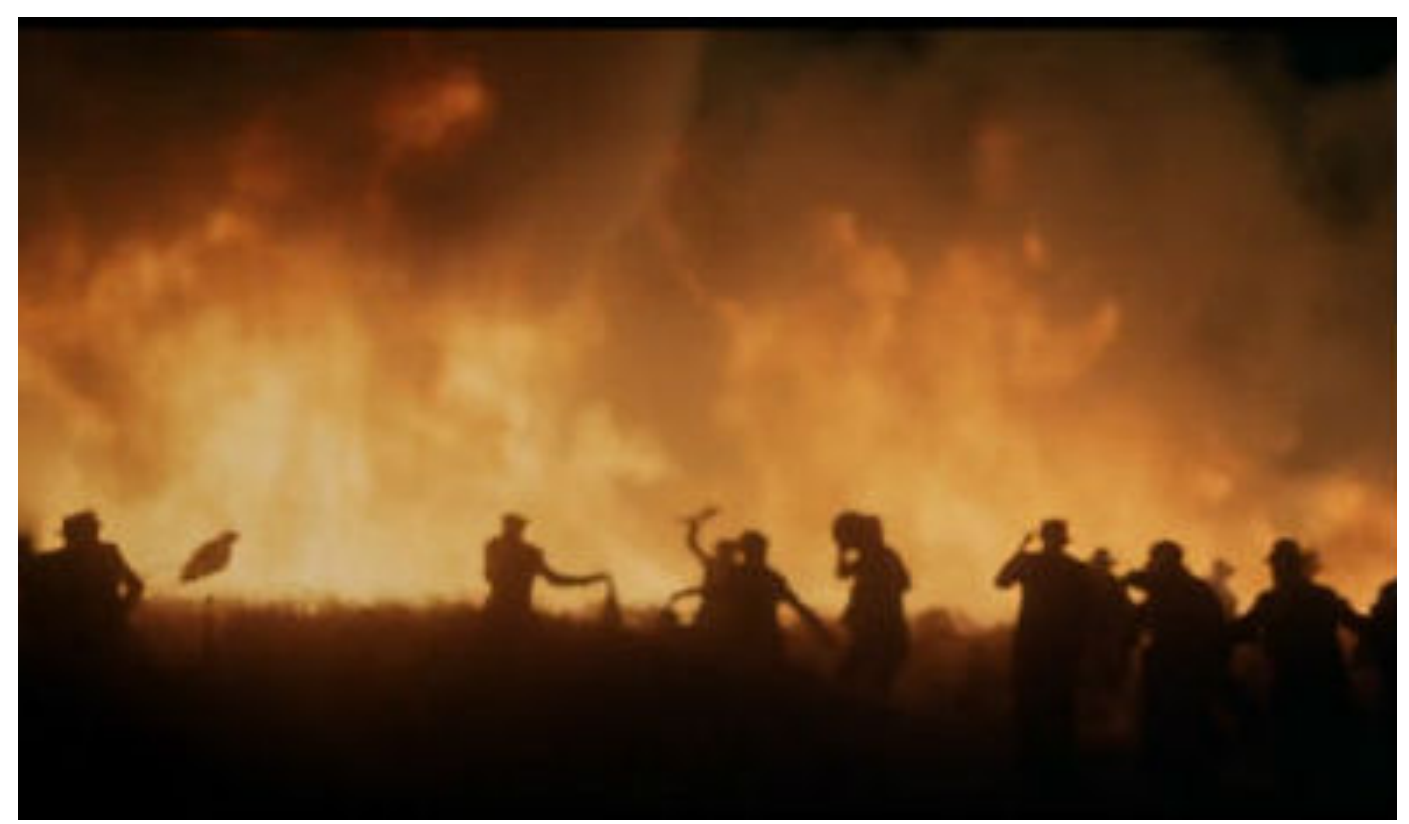

Os campos de trigo em chamas: fim da praga de gafanhotos e fim da ceifa 
Além da linha vermelha

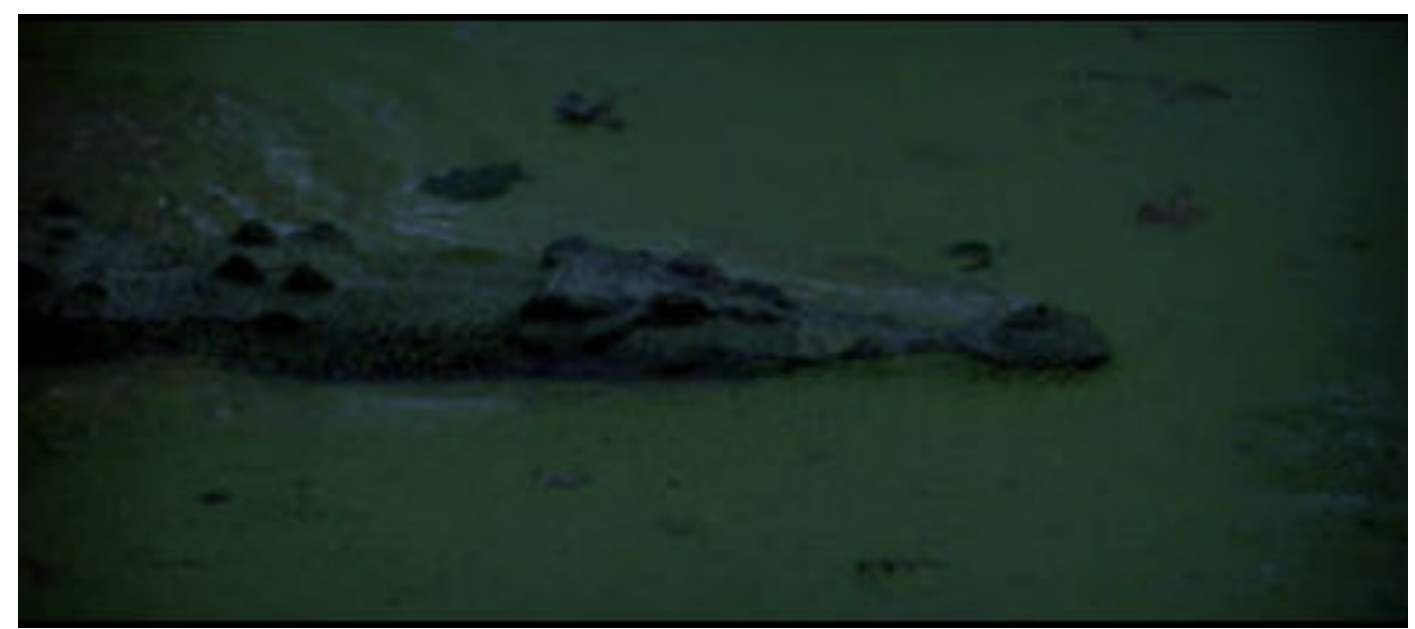

Crocodilo afunda em água pantanosa: cena de abertura do filme

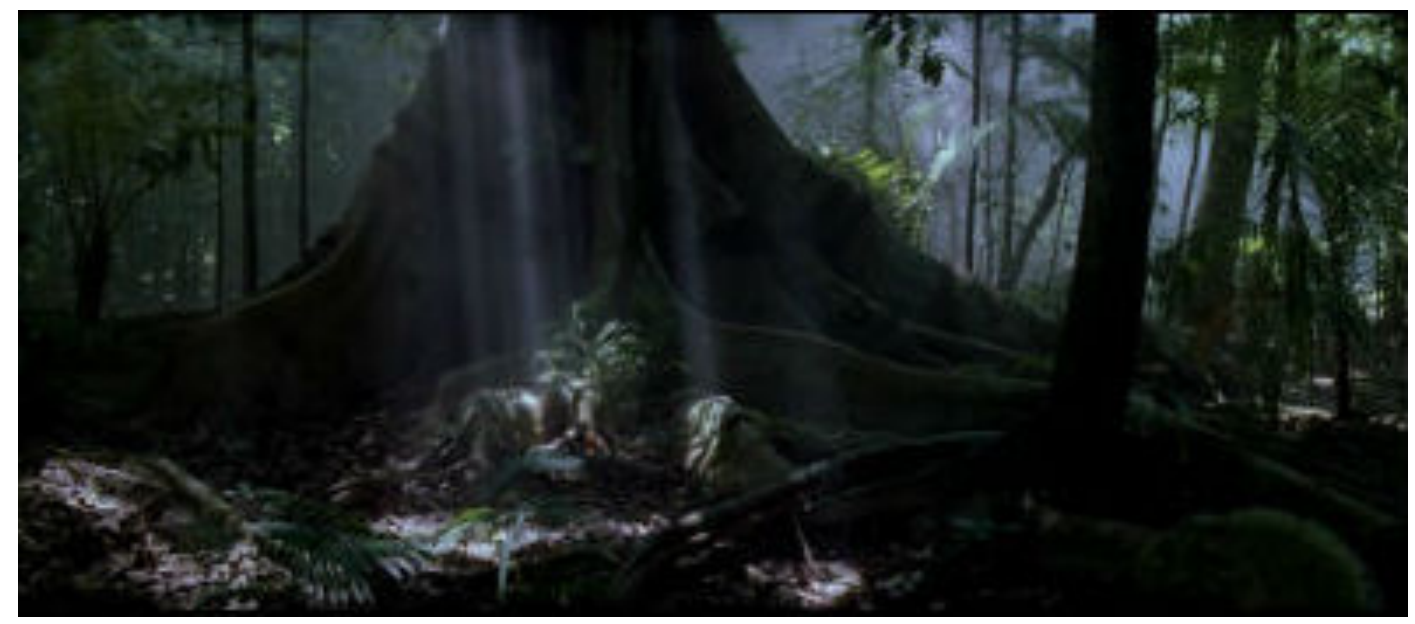

Feixes de luz encostam nas raízes da majestosa árvore: o toque do divino sobre a natureza 


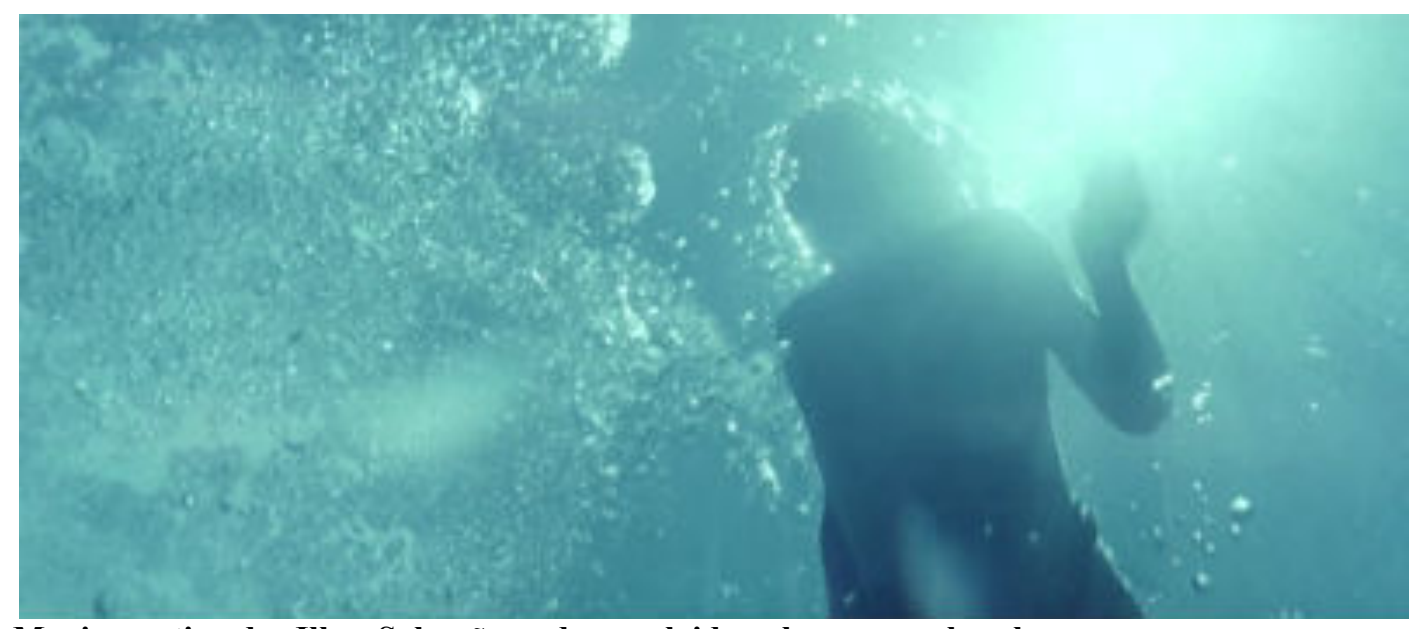

Menino nativo das Ilhas Salomão nada envolvido pelo mar e pelo sol

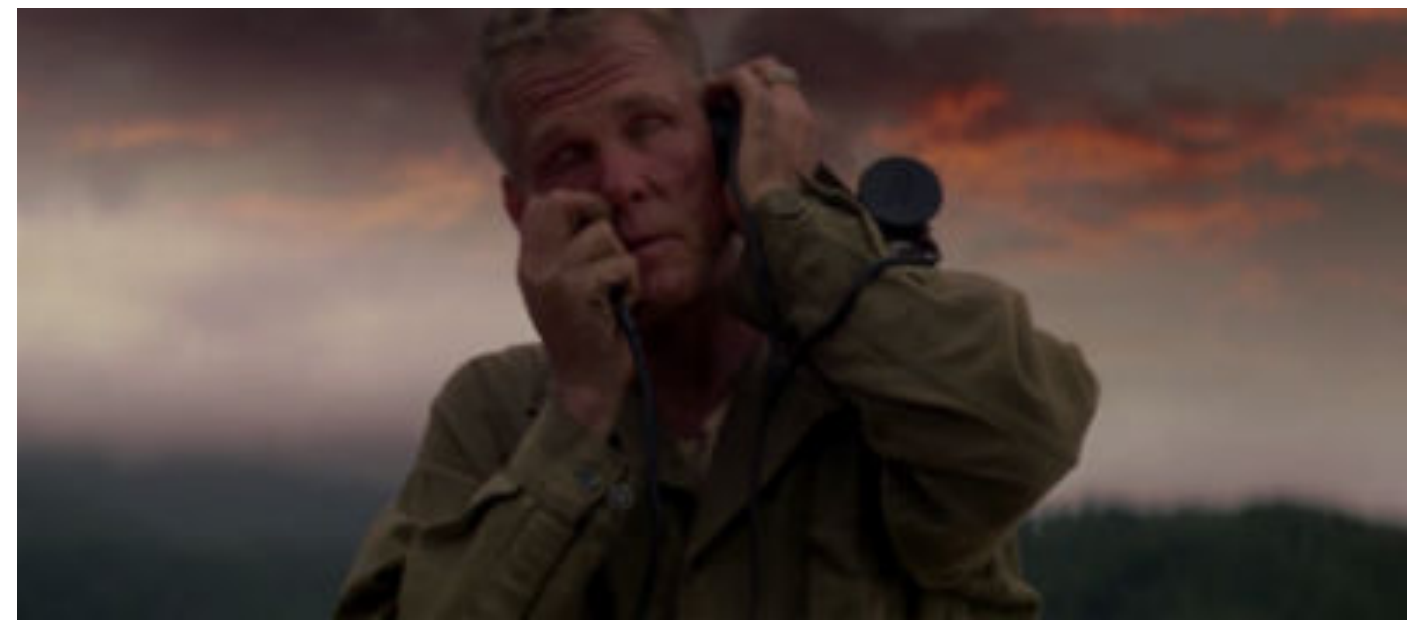

Tenente-coronel Tall fala com os superiores em frente ao céu flamejante

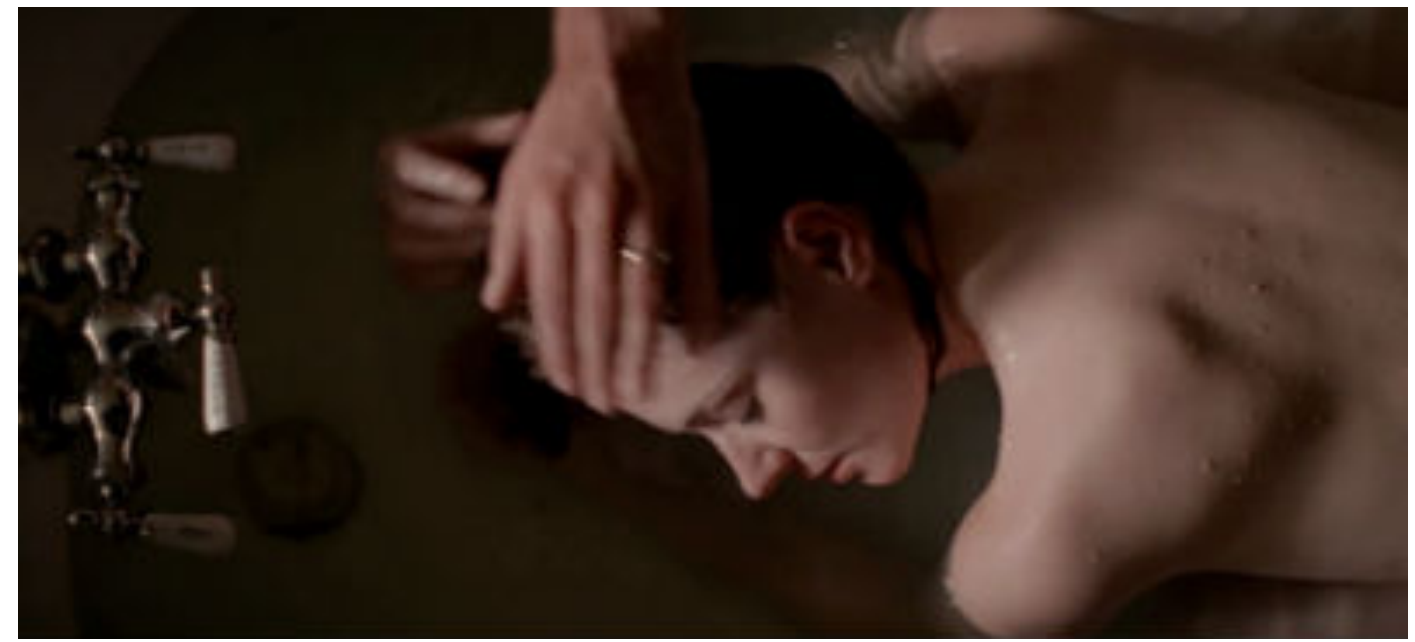

Marty recebe afago do marido, Private Bell, durante o banho 


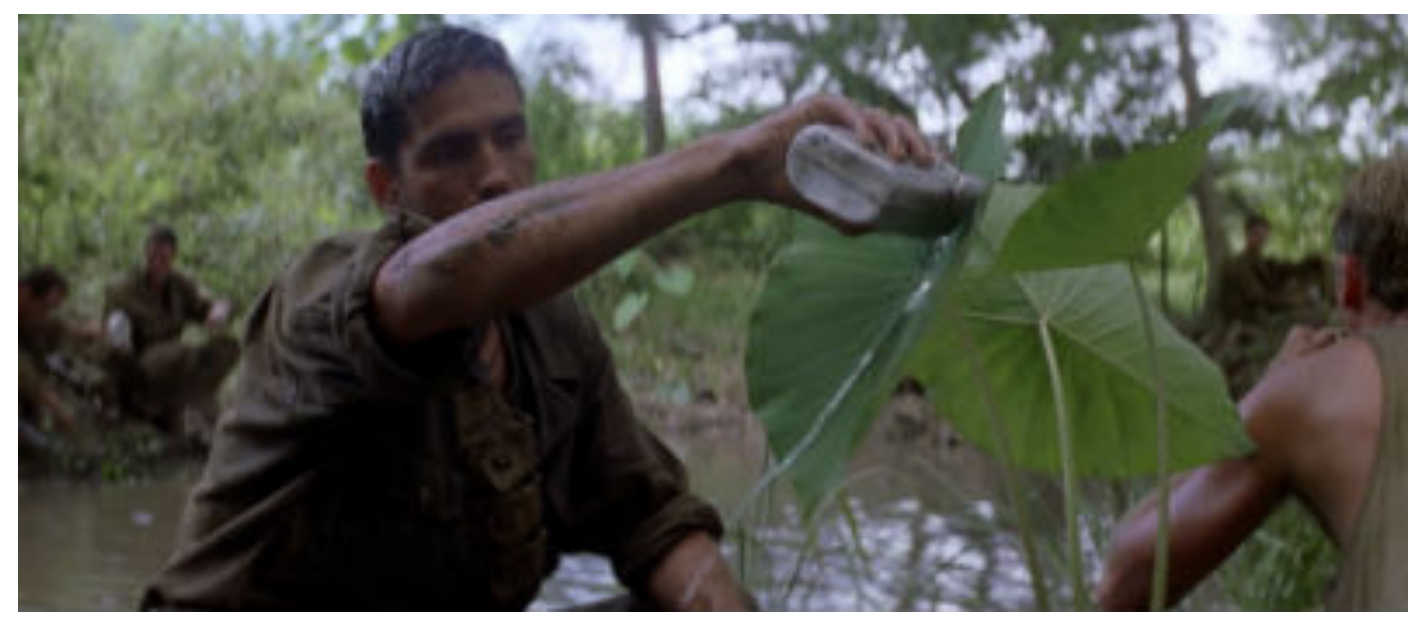

Private Witt derrama sobre a planta o resto da água do cantil: cuidado com a natureza

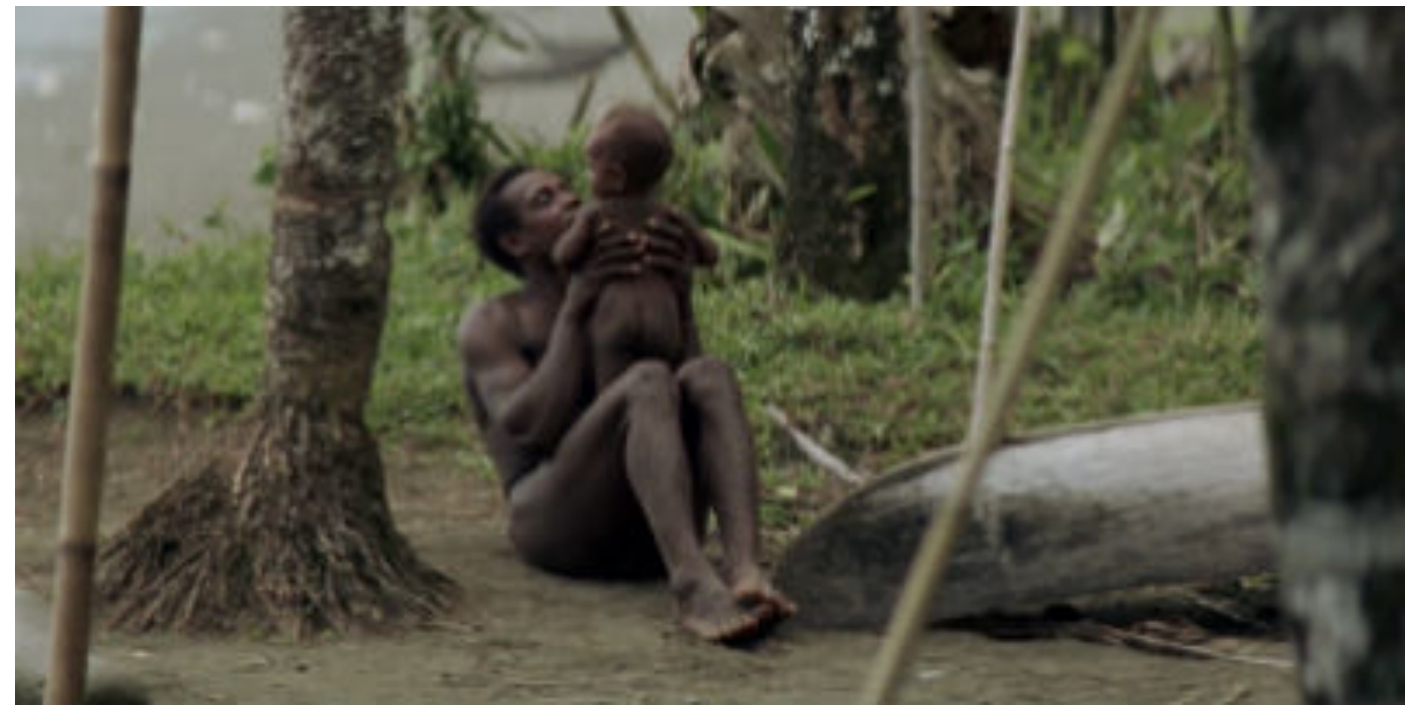

Pai e filho nativos das lhas Salomão em momento espontâneo: câmera natural

\section{O novo mundo}

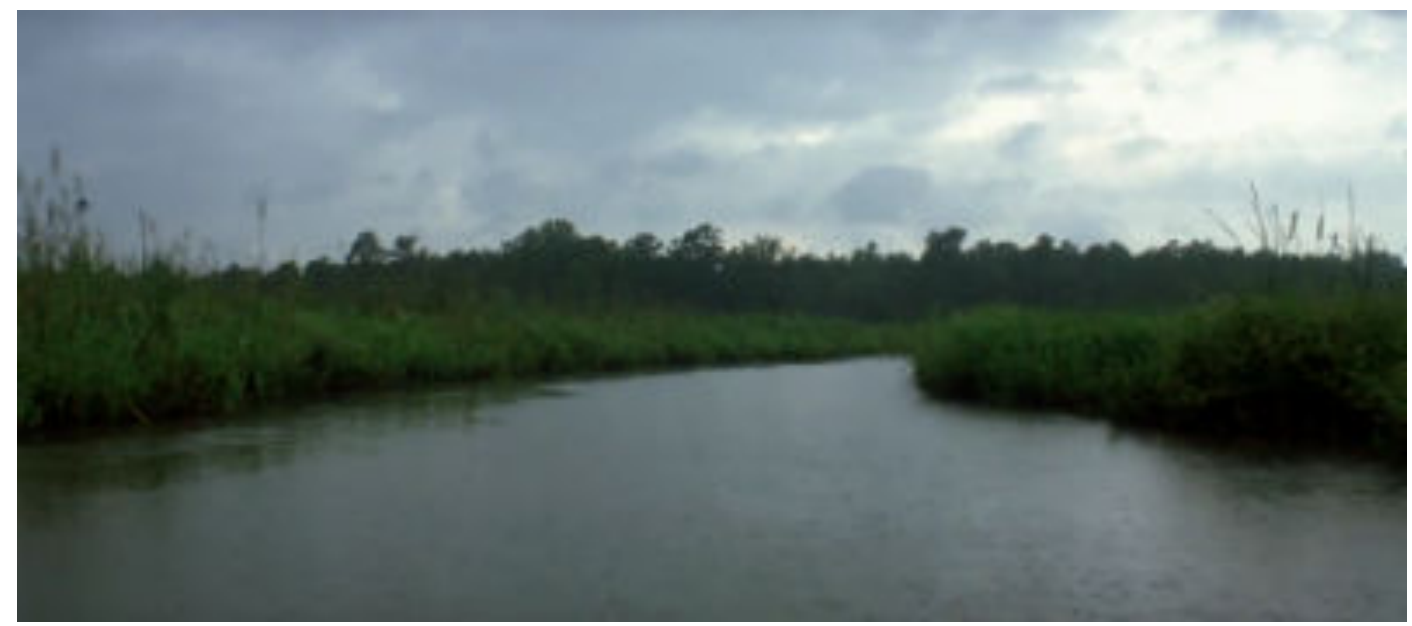

Curso de água do rio que alimenta a terra dos indígenas Powhatan: paisagem recorrente 


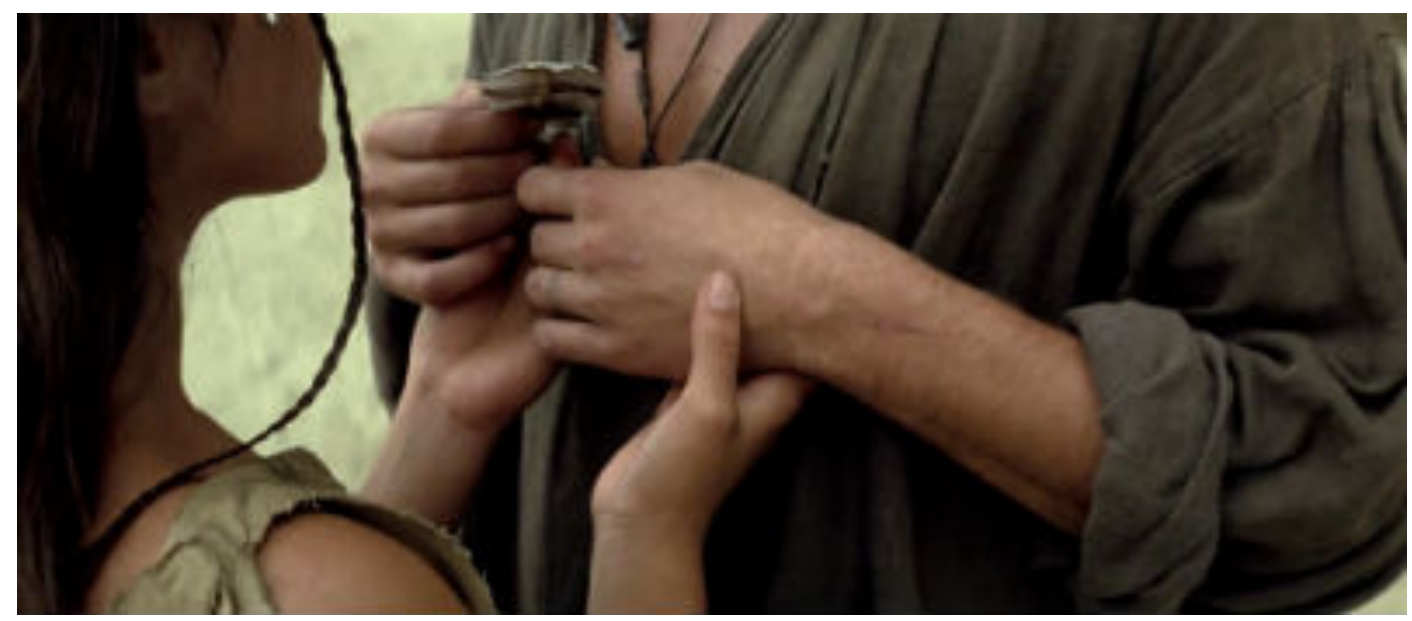

Pocahontas entrega a pena de seu cabelo a Capitão Smith: cumplicidade

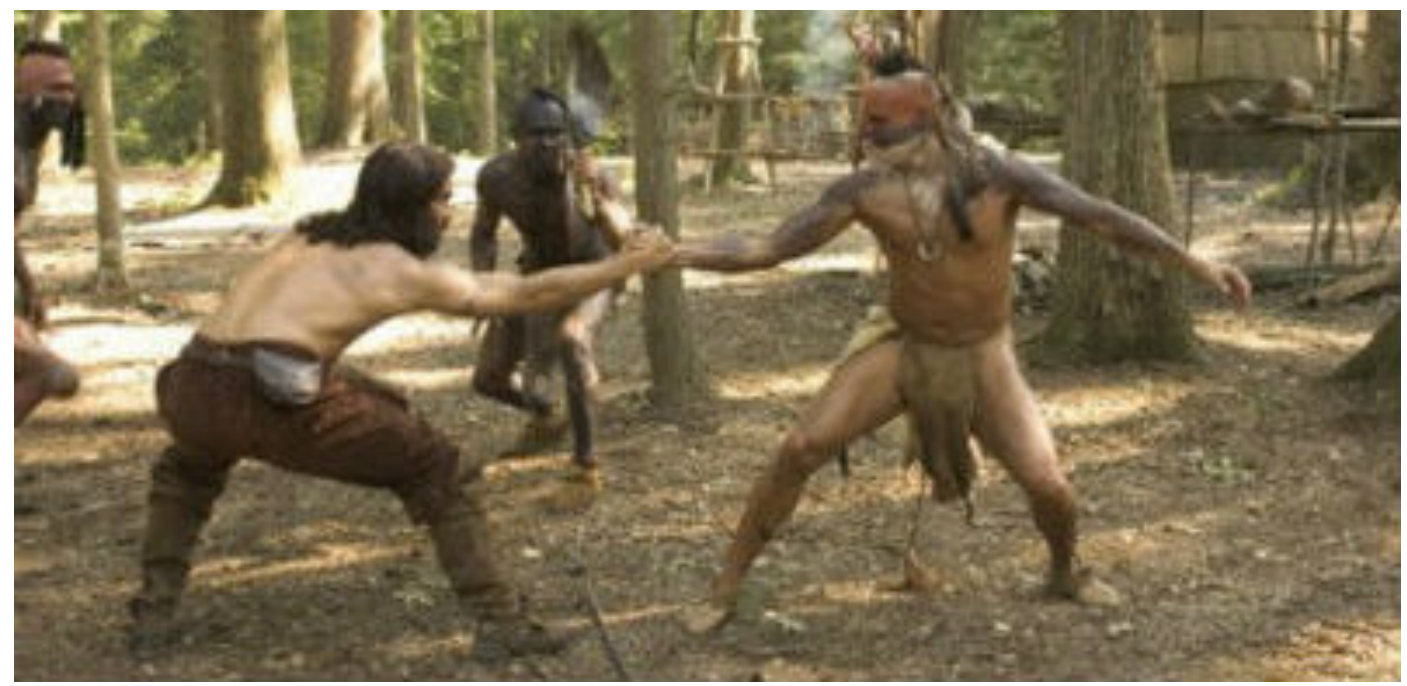

Smith mede forças com Tomococo em uma das brincadeiras da tribo

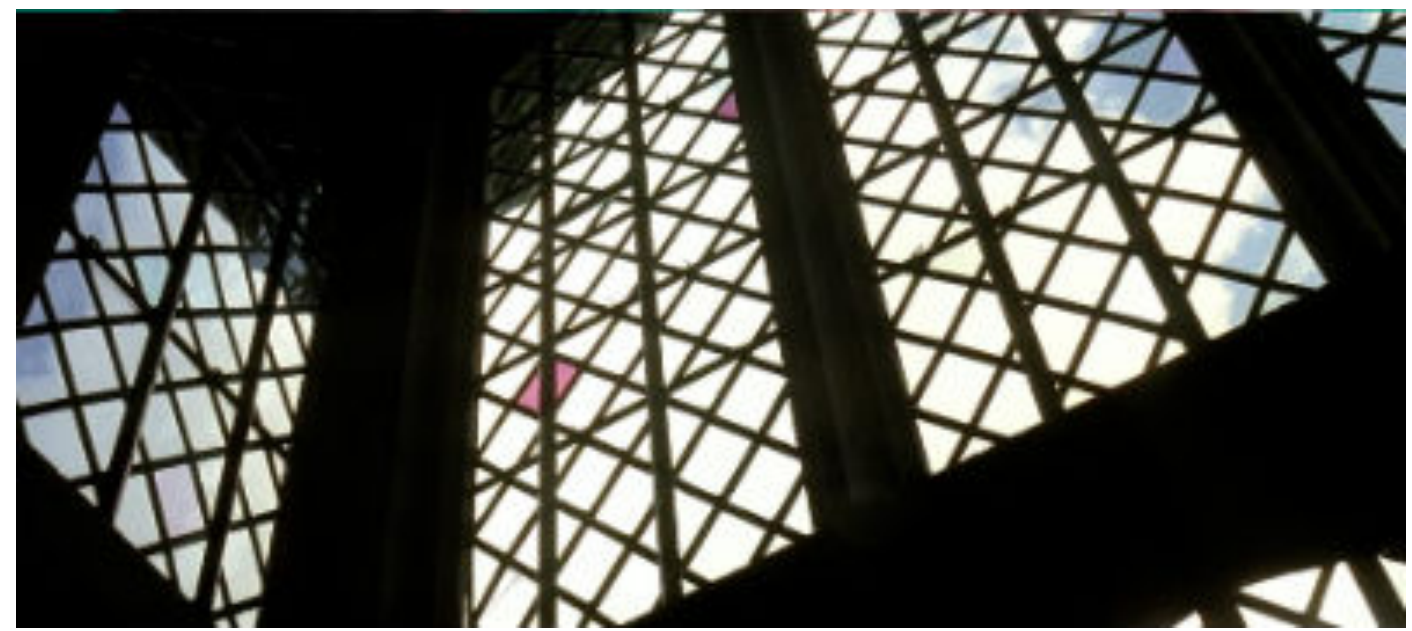

Um palacete europeu visto de dentro para fora, revelando o céu por entre vitrais 


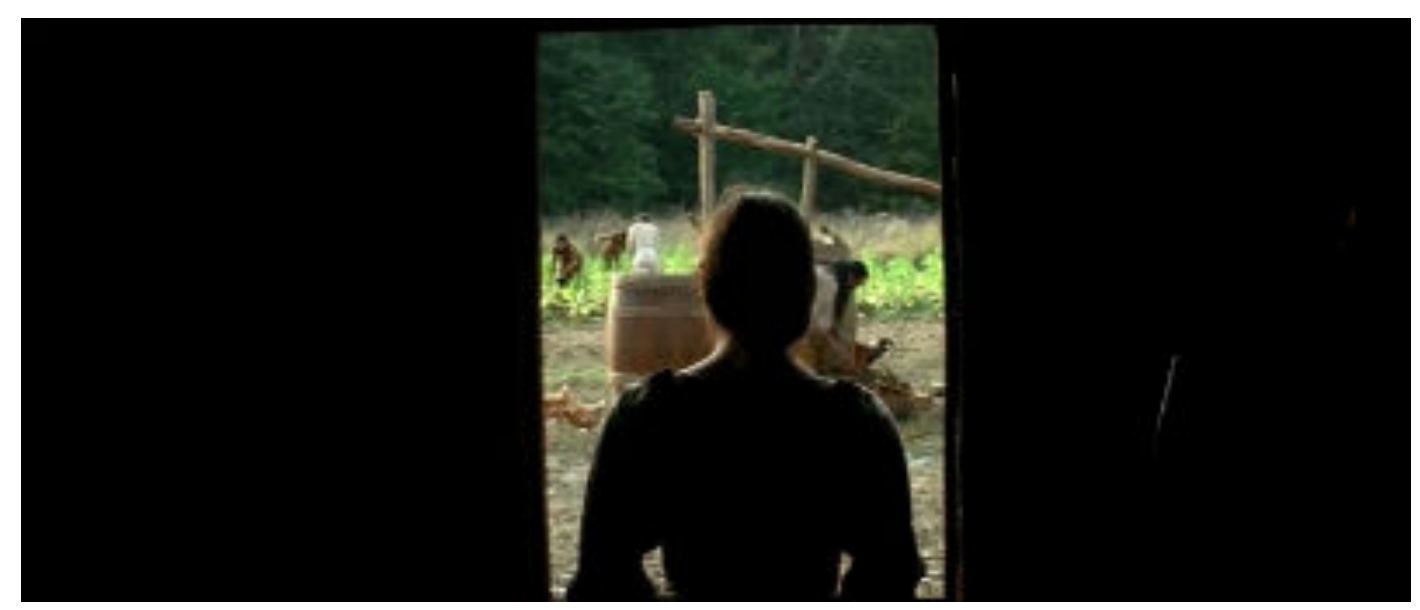

Pocahontas observa o trabalho da comunidade na plantação e no poço

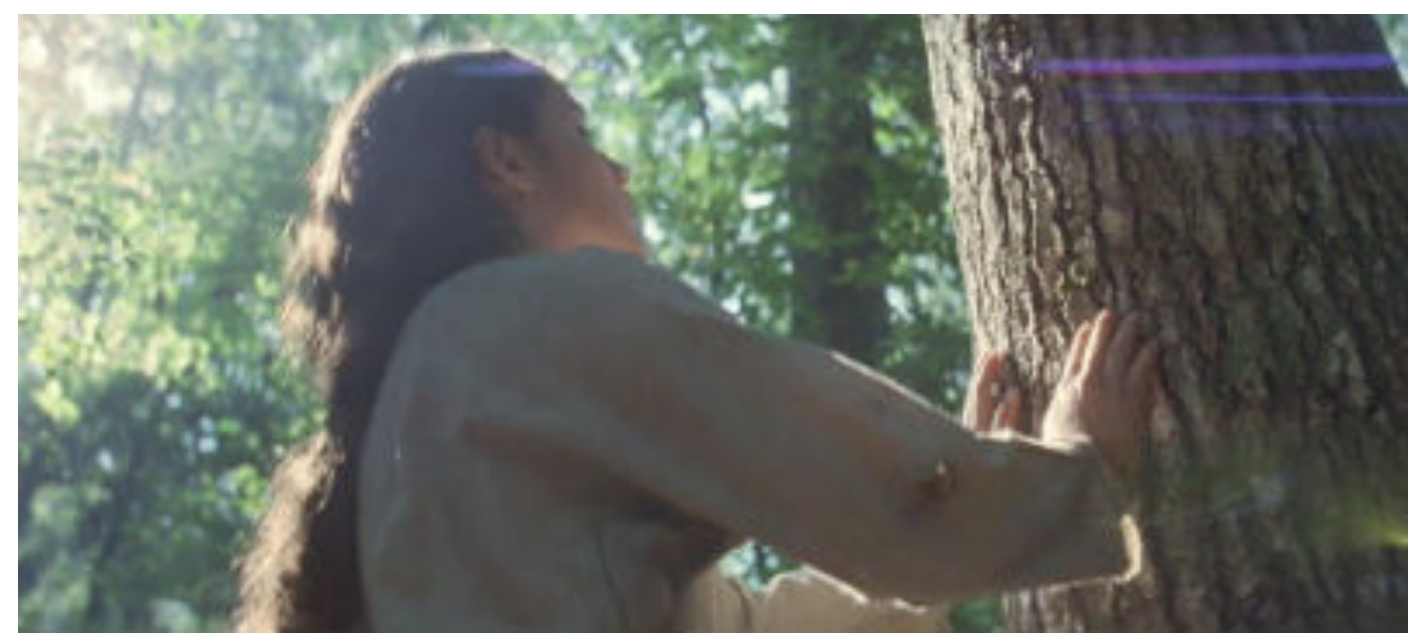

Pocahontas toca a árvore enquanto fala com a Mãe Terra: prece em voz over

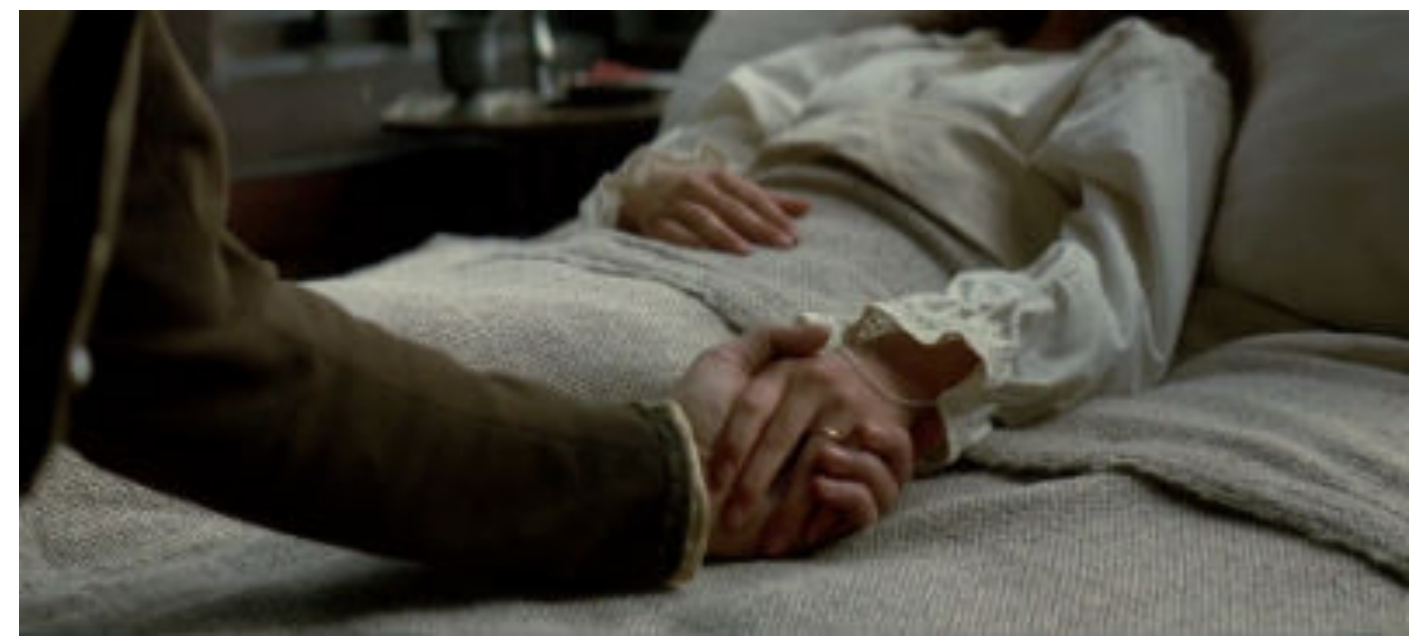

Mãe de John Rolfe recebe consolo em seu leito: o toque como agente consolador 


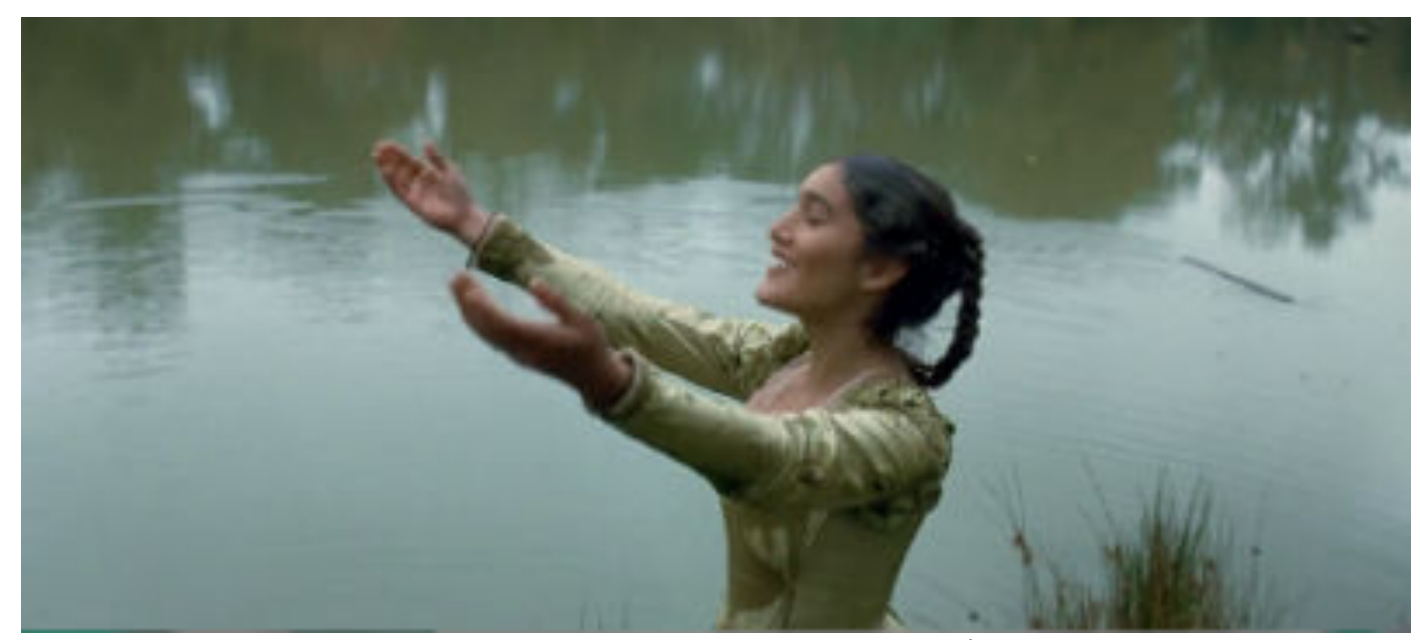

Pocahontas se reconecta com a natureza longe de sua terra: gratidão à Mãe Terra

\section{A árvore da vida}

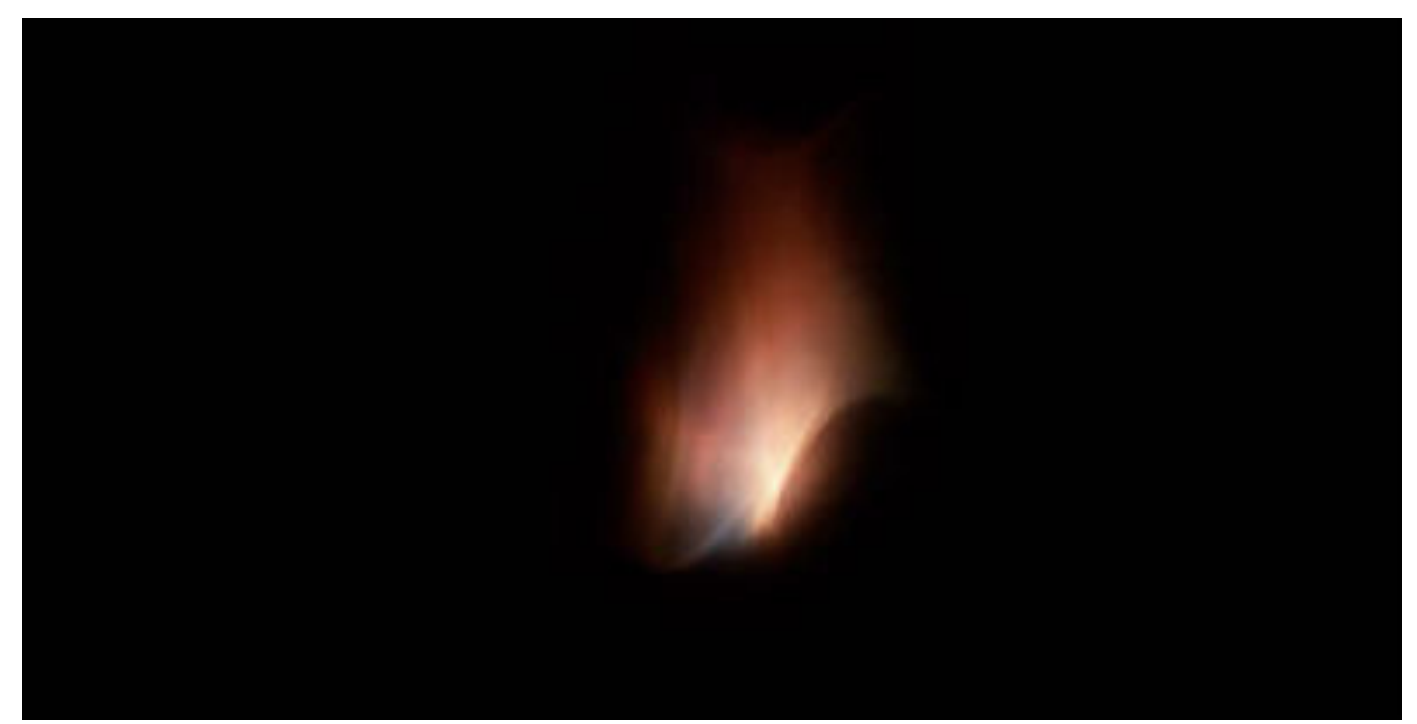

A chama que metaforiza o início e o fim do ciclo da vida: marcação dos capítulos do filme 


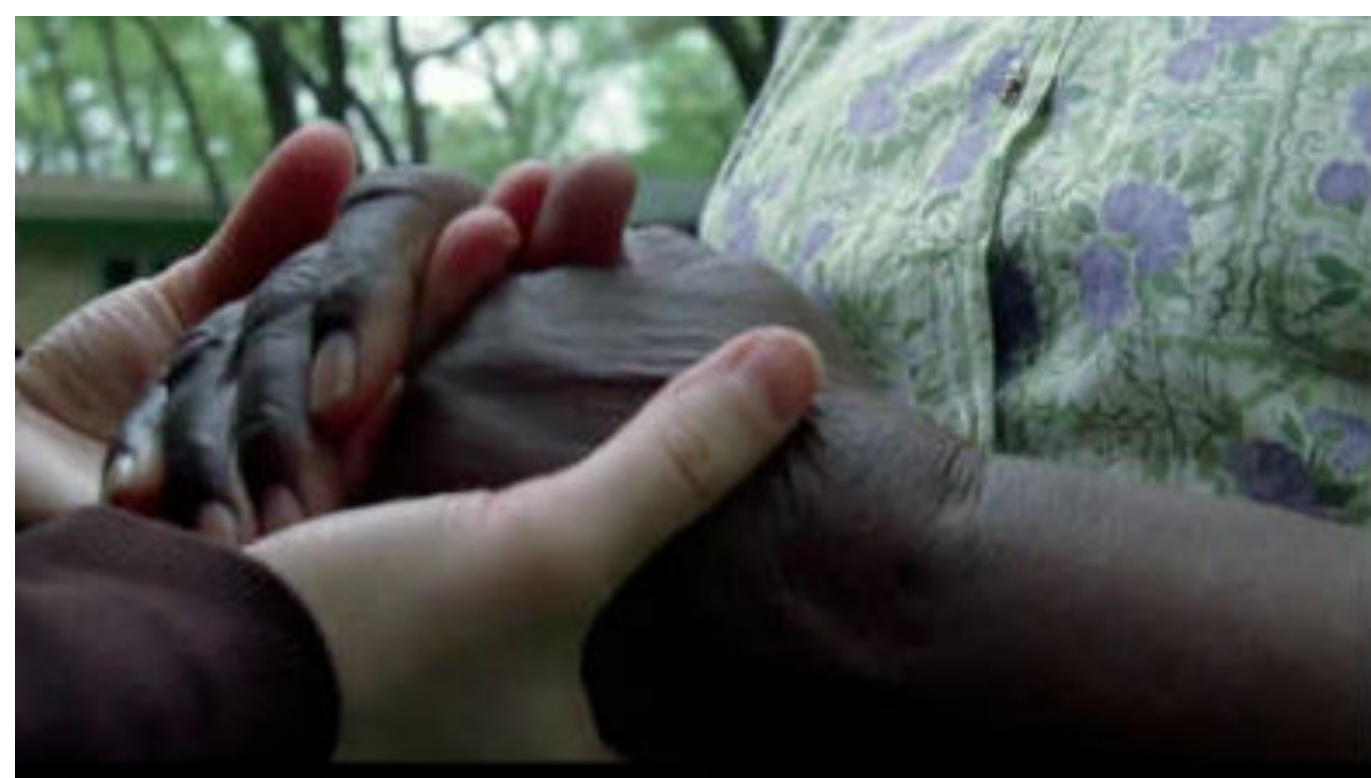

Mrs. O'Brien recebe consolo após a morte do filho: mais uma vez, as mãos piedosas

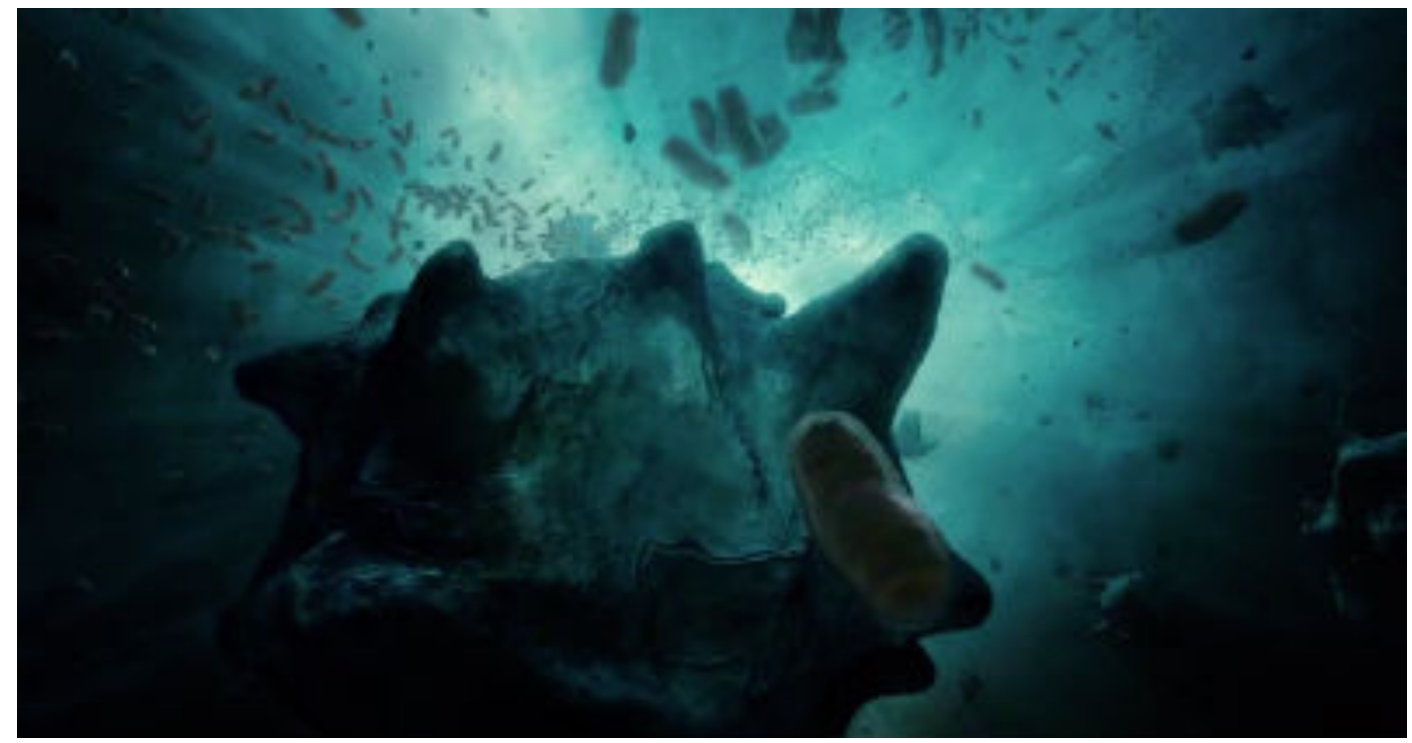

Os primeiros assomos da vida na Terra: sequência da evolução do mundo 


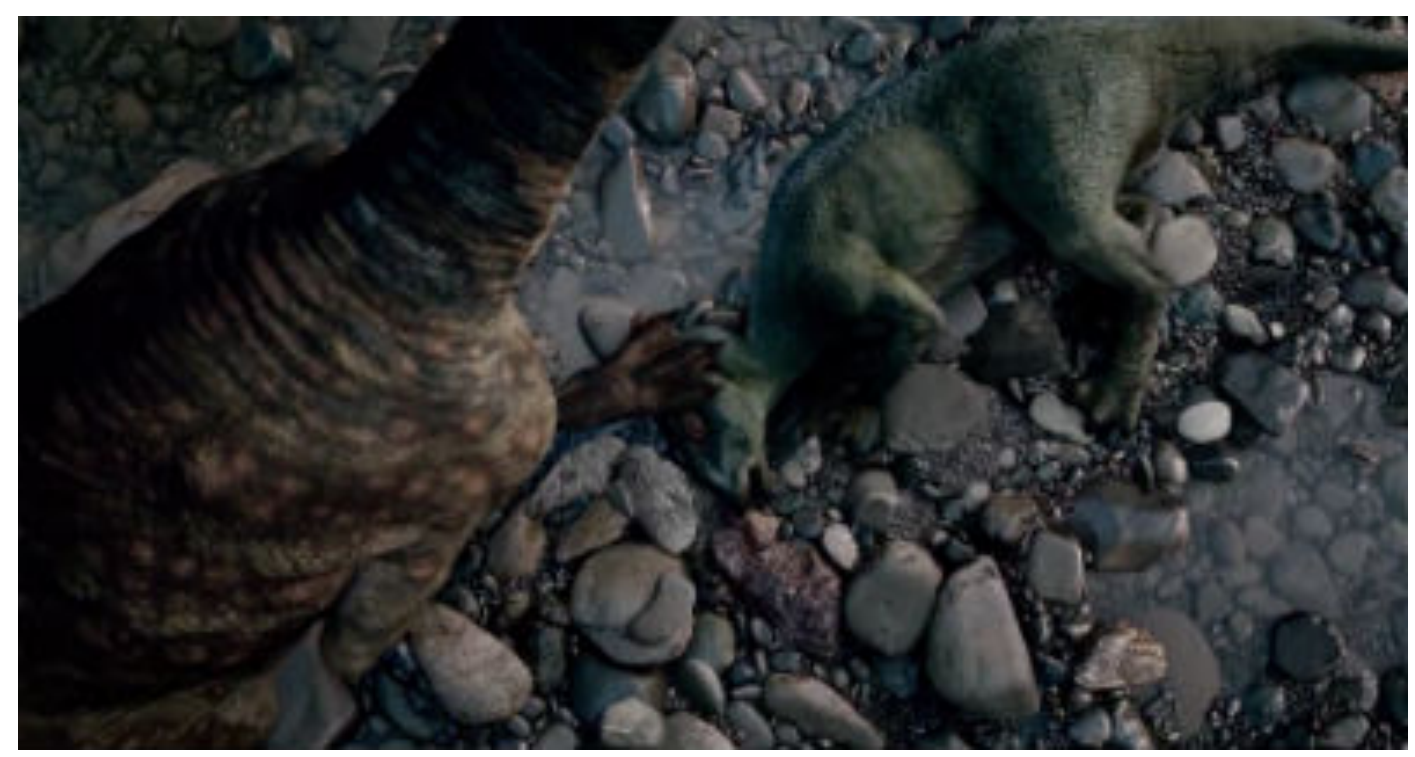

Um dinossauro subjuga outro mas logo o liberta: gesto de misericórdia

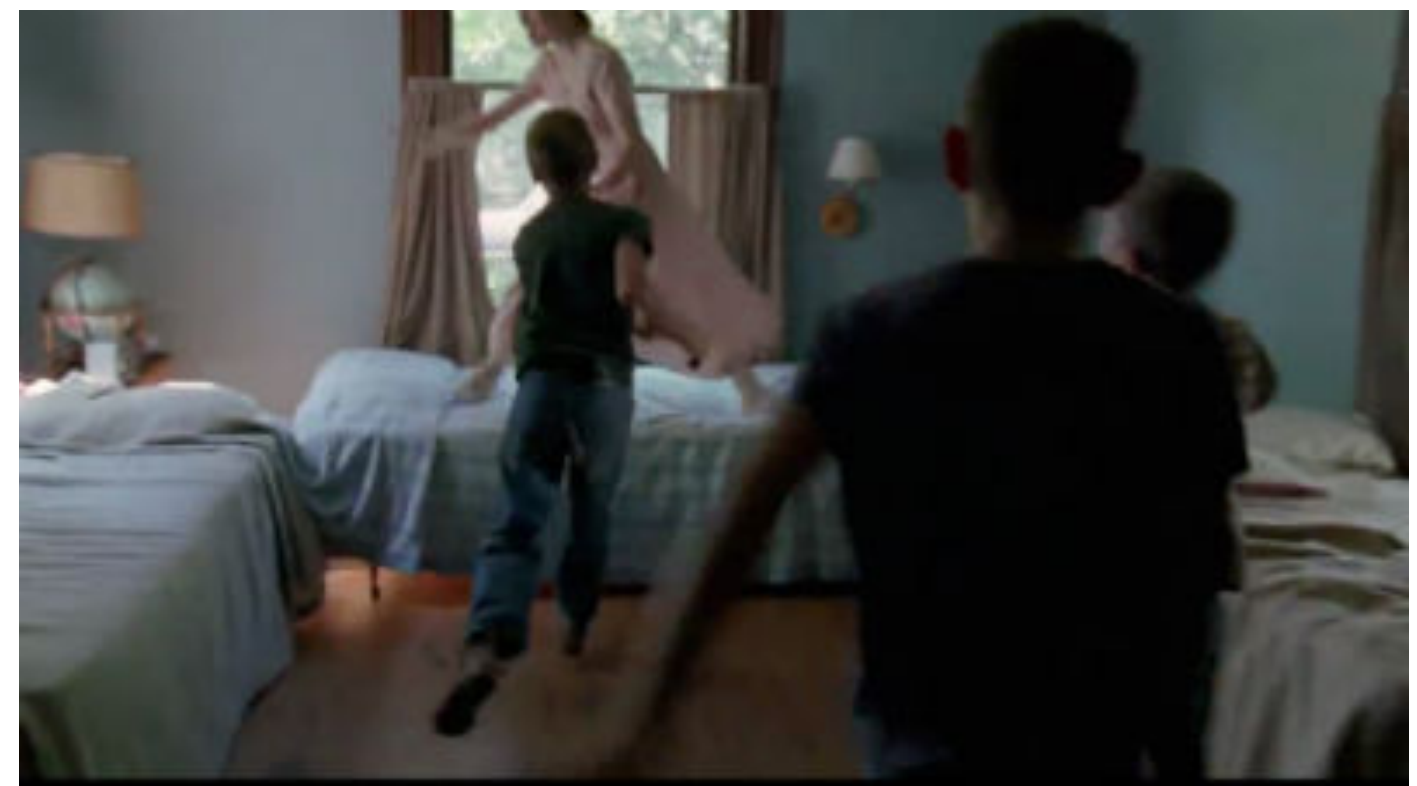

Os meninos correm atrás da mãe em uma brincadeira em que a ameaçam com um lagarto 


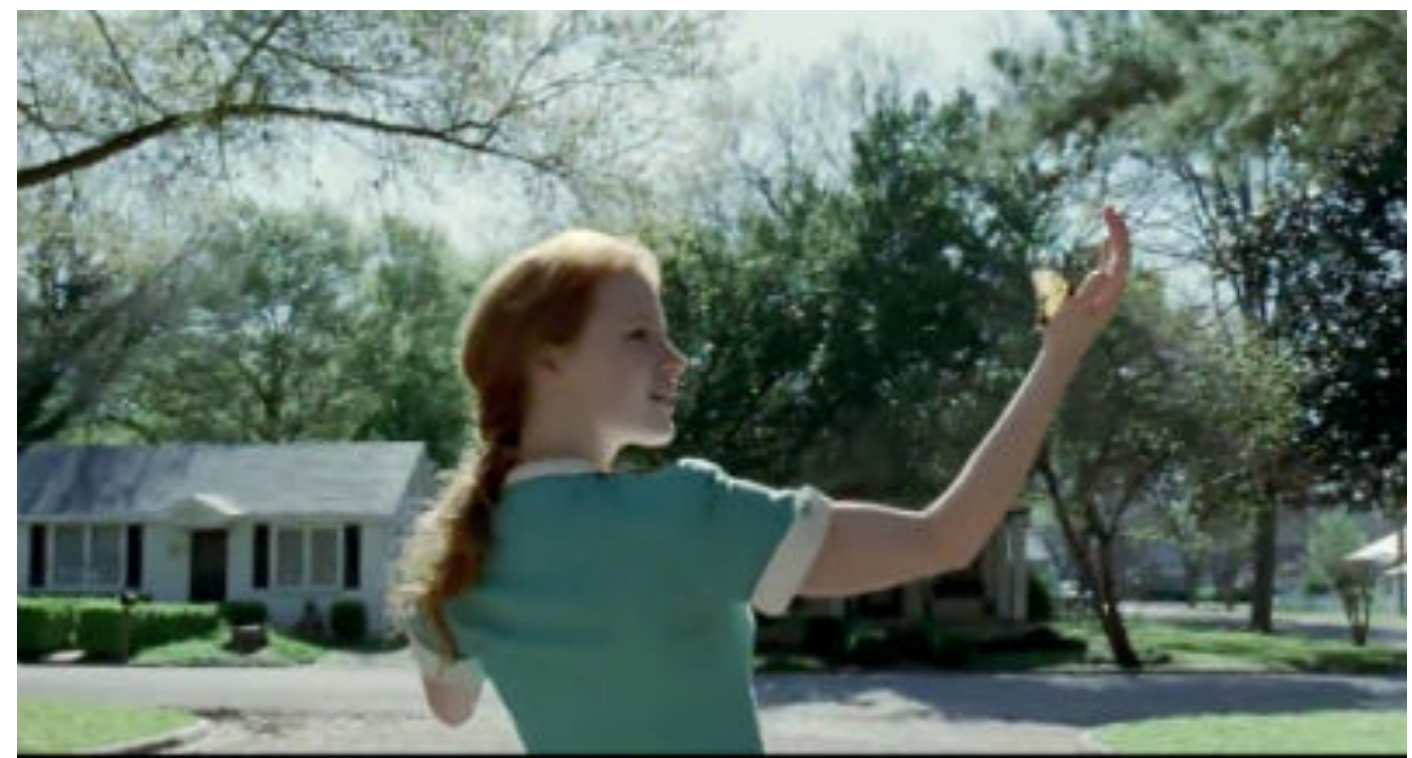

Mrs. O'Brien se distrai perseguindo uma borboleta no quintal: momento espontâneo

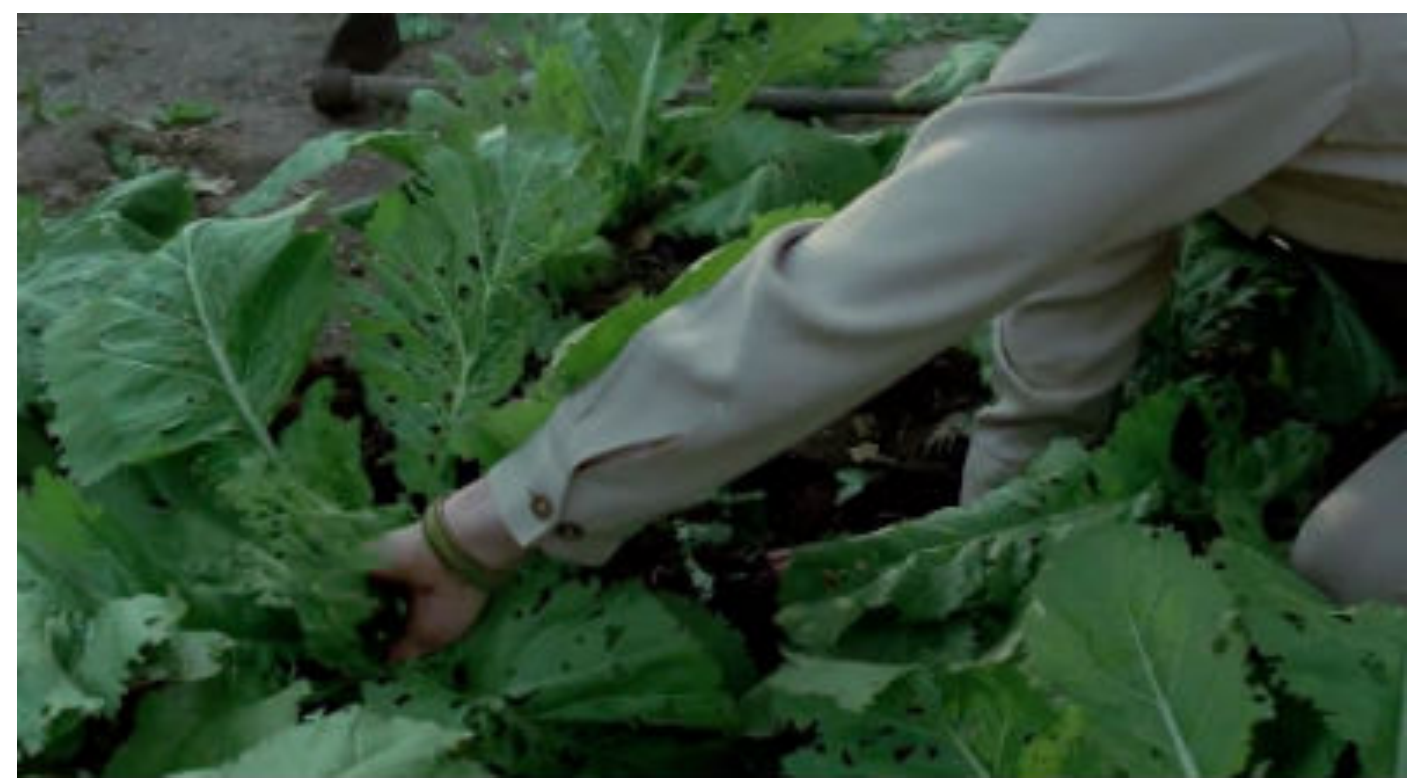

Mr. O’Brien cuida da horta em momento que ensinará o filho mais velho o valor do trabalho 


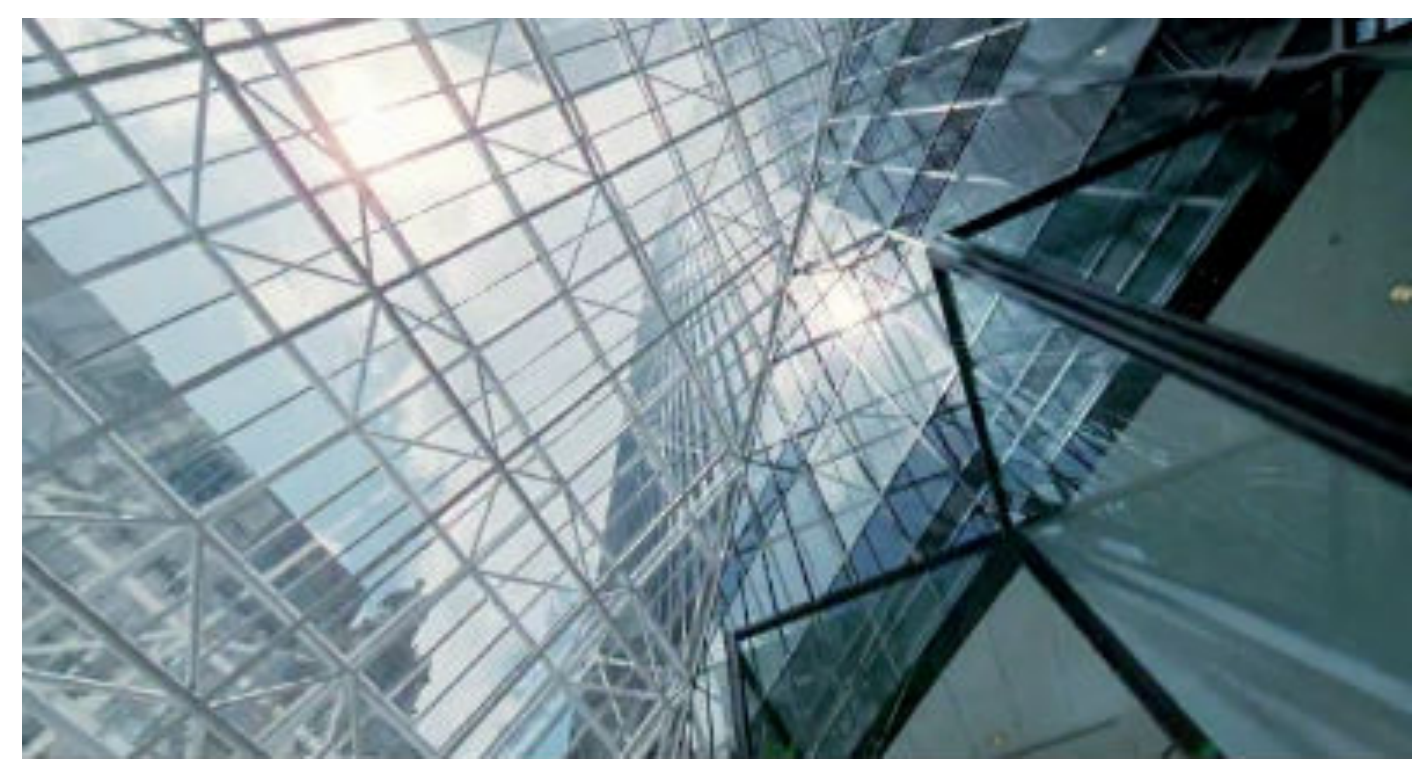

Visão do céu de dentro do suntuoso edifício onde Jack trabalha como arquiteto

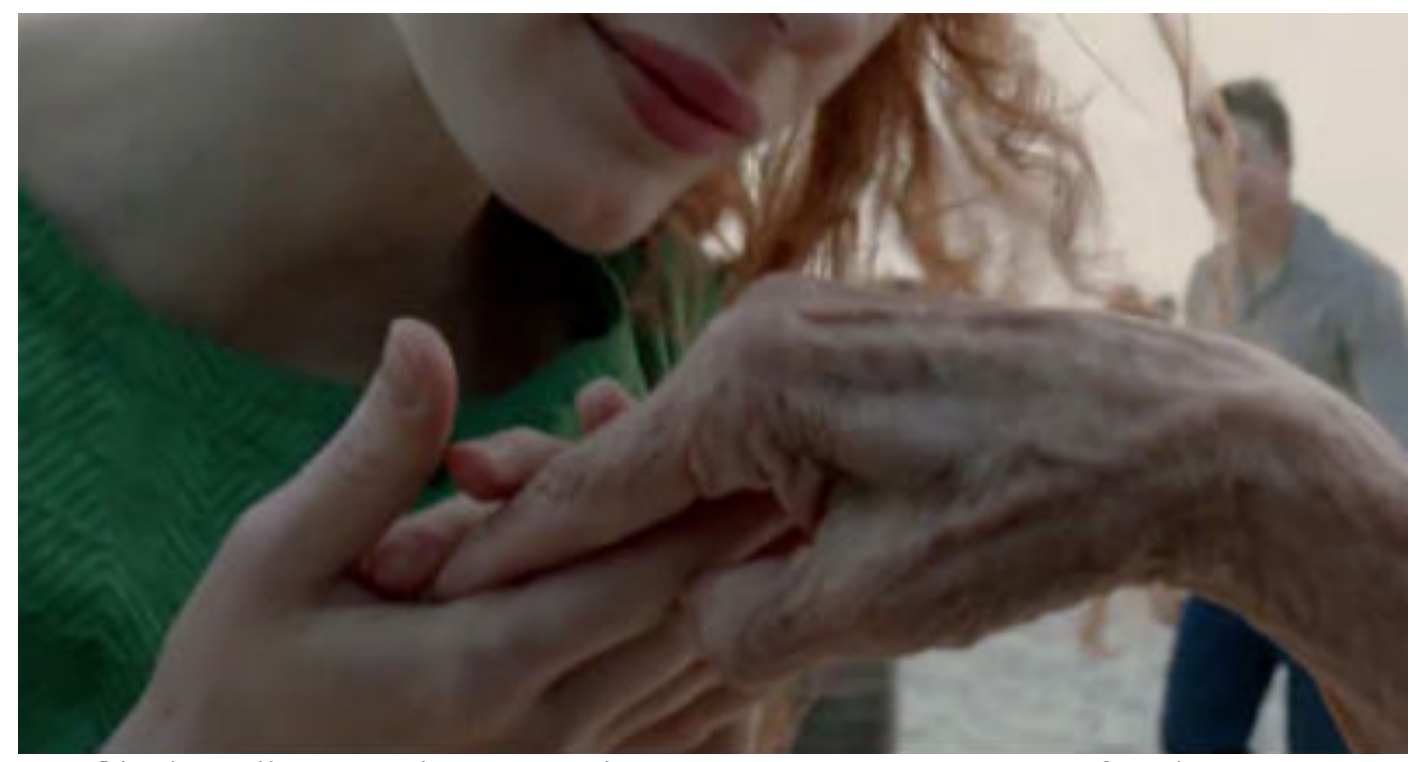

Mrs. O’Brien beija mão de idosa na praia onde se reencontra com toda a família 


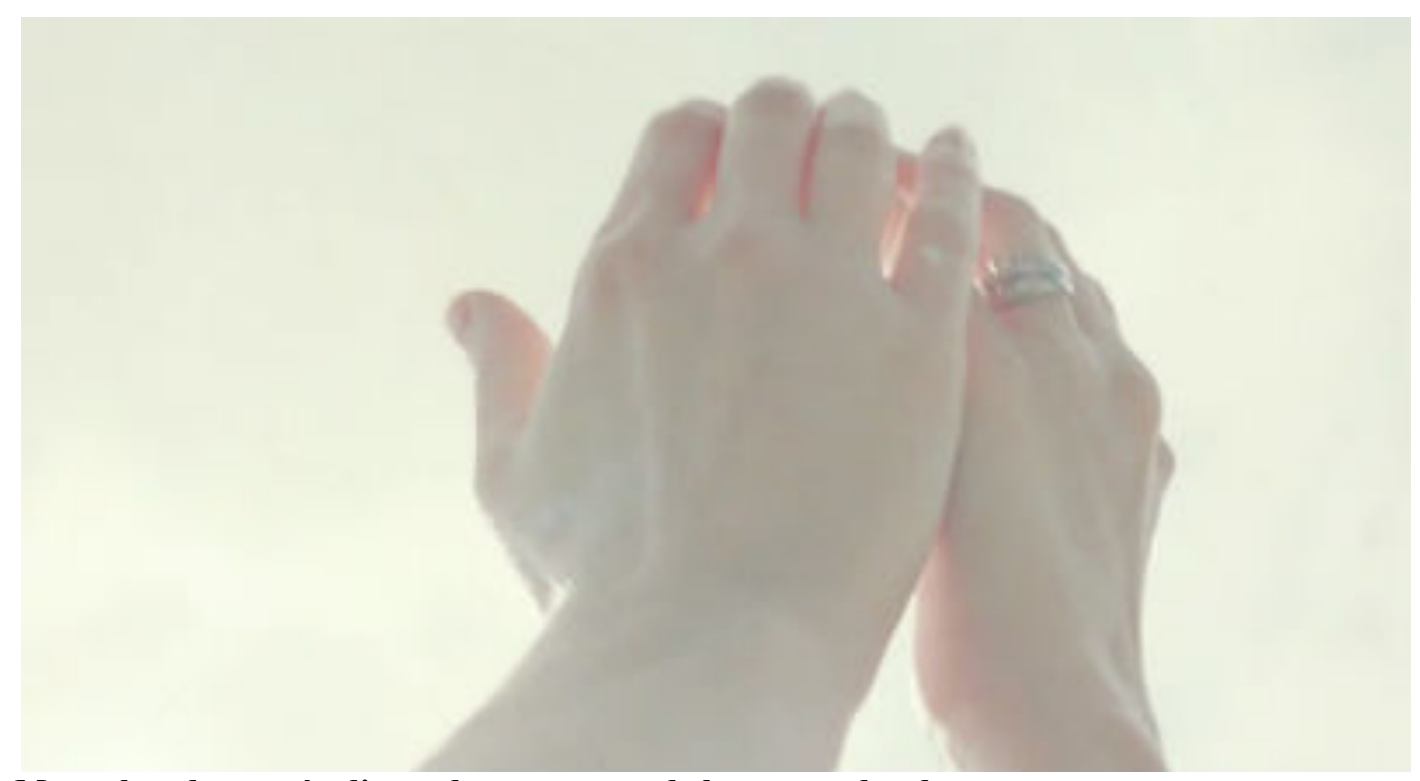

Mãos elevadas ao céu diante de um excesso de luz: gesto de adoração

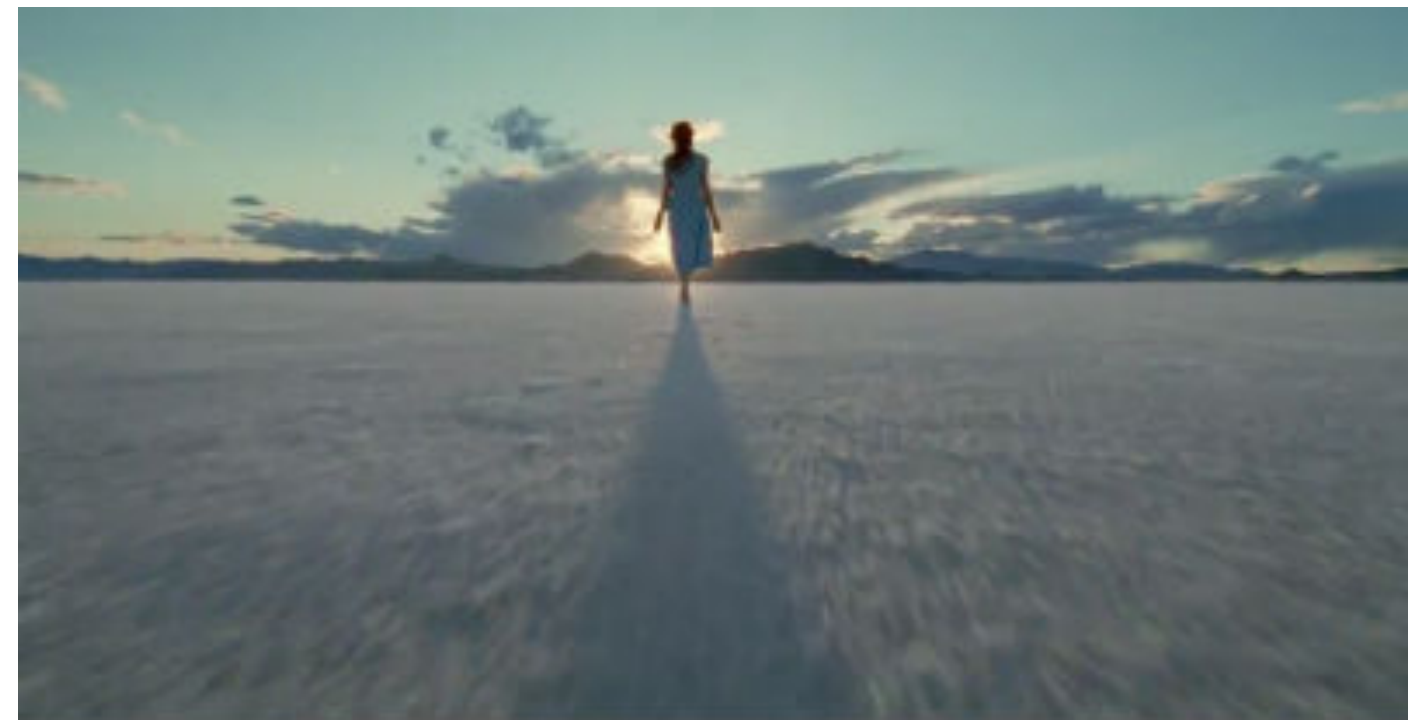

Mrs. O'Brien caminhando na direção do horizonte em um chão como o de nuvens 


\section{Amor pleno}

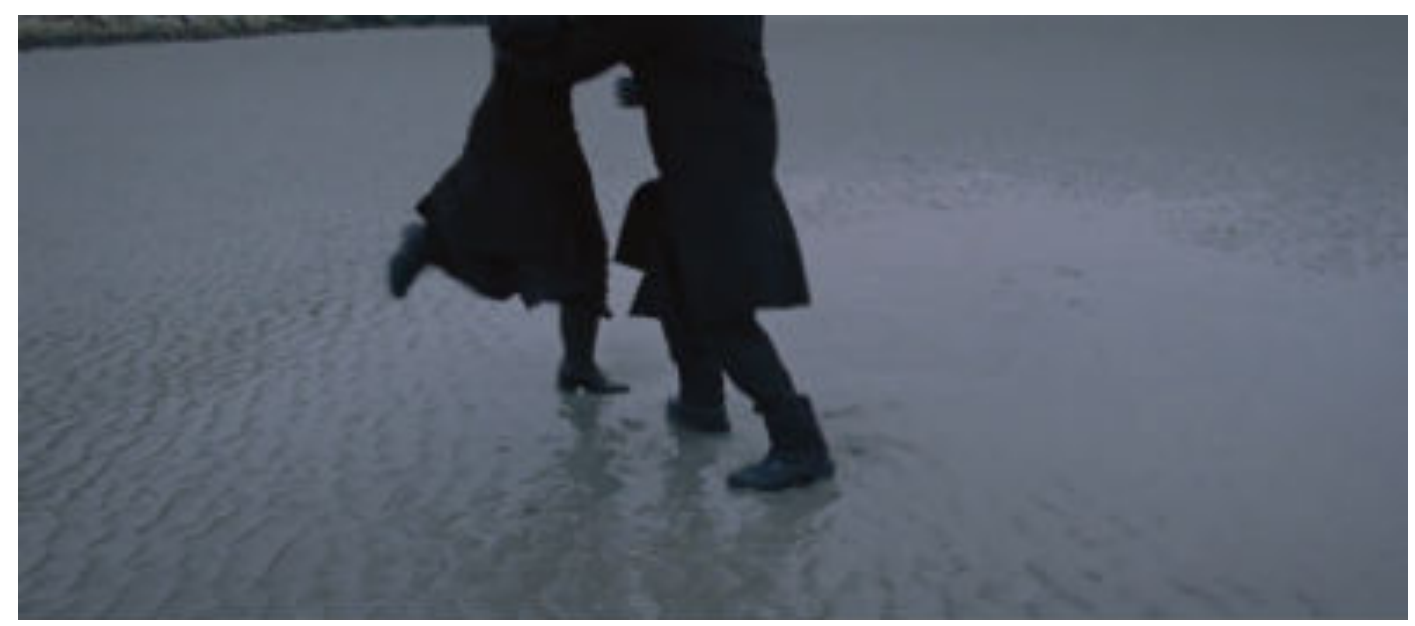

Marina e Neil sobre a terra fofa e molhada de uma praia: brincadeiras apaixonadas

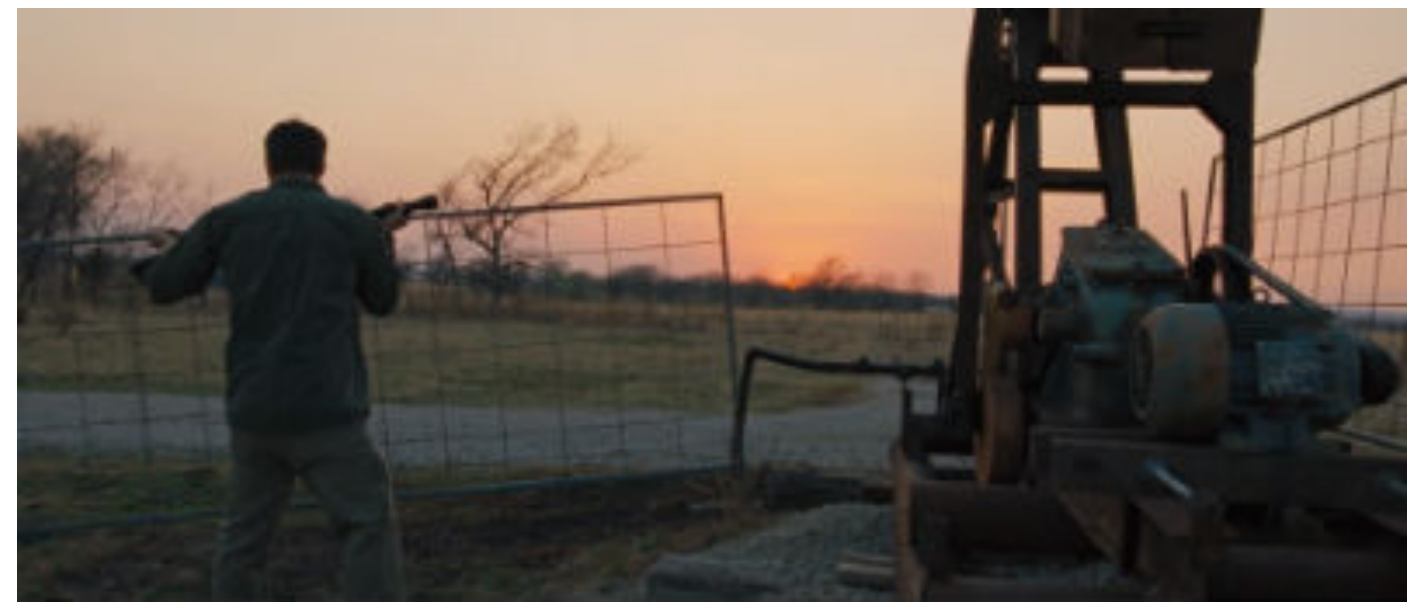

Neil retira cerca de um maquinário em funcionamento: o trabalho braçal 


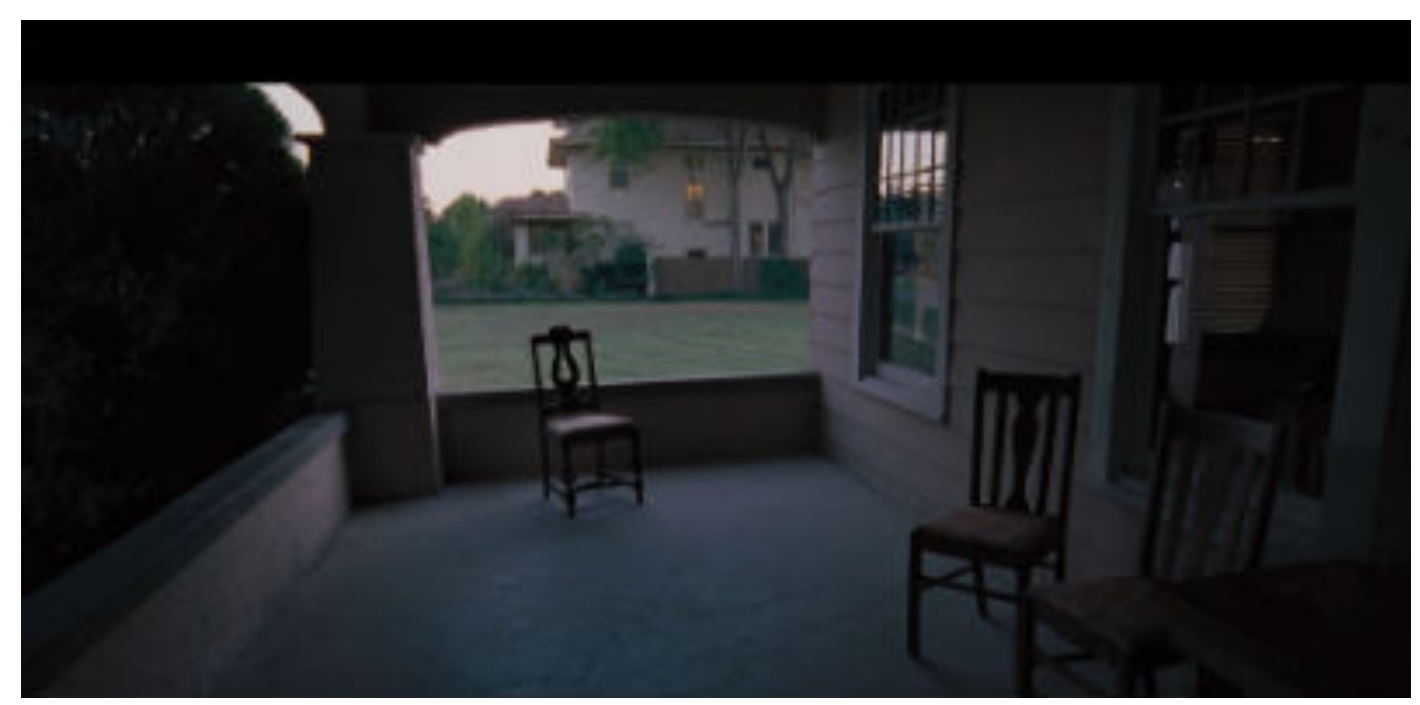

Varanda vazia durante visita do Padre Quintana: a fé vazia encontra habitantes fantasmas

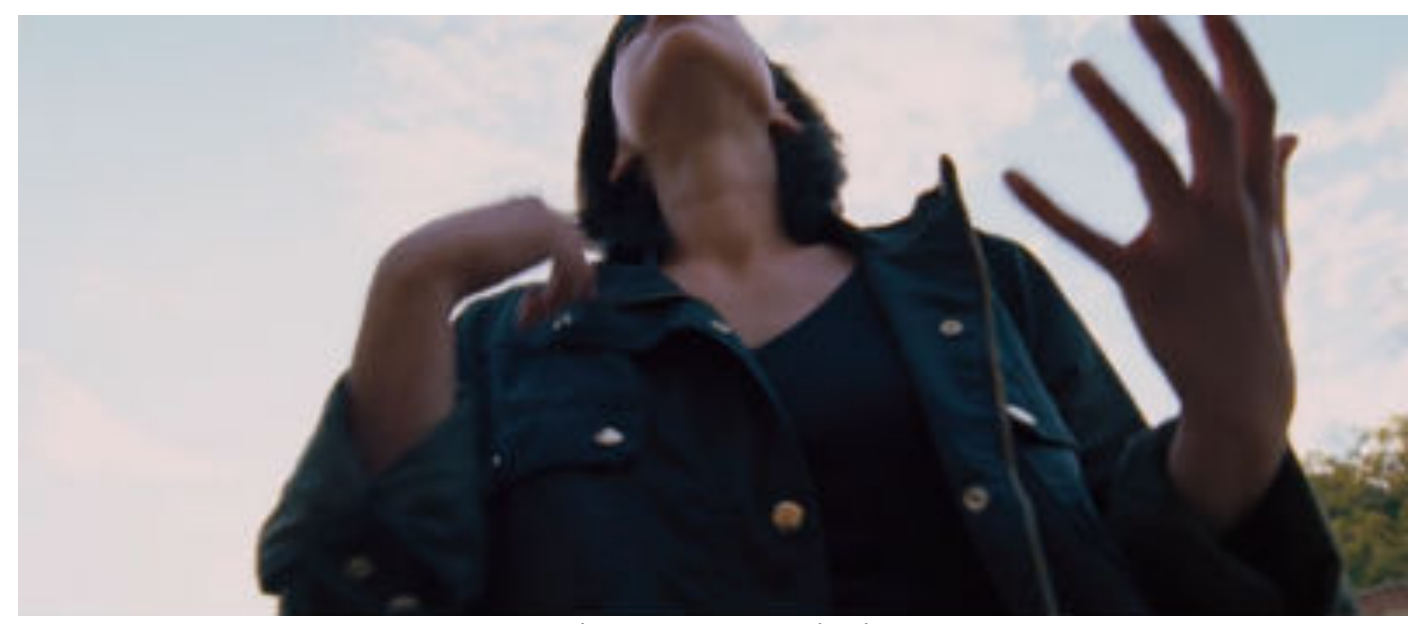

Moça conversa se expressando por meio de língua de sinais: contra-plongée bucando o céu

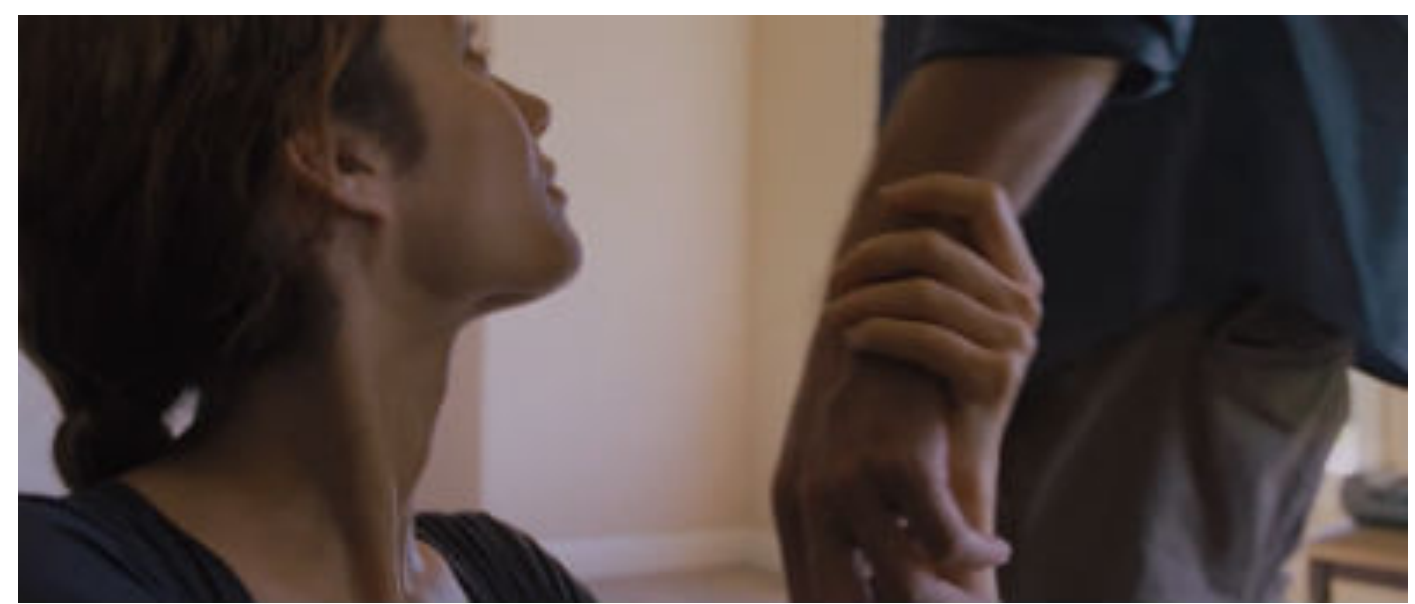

Marina tenta segurar a mão de Neil, indiferente a ela: movimento de atração e repulsão 


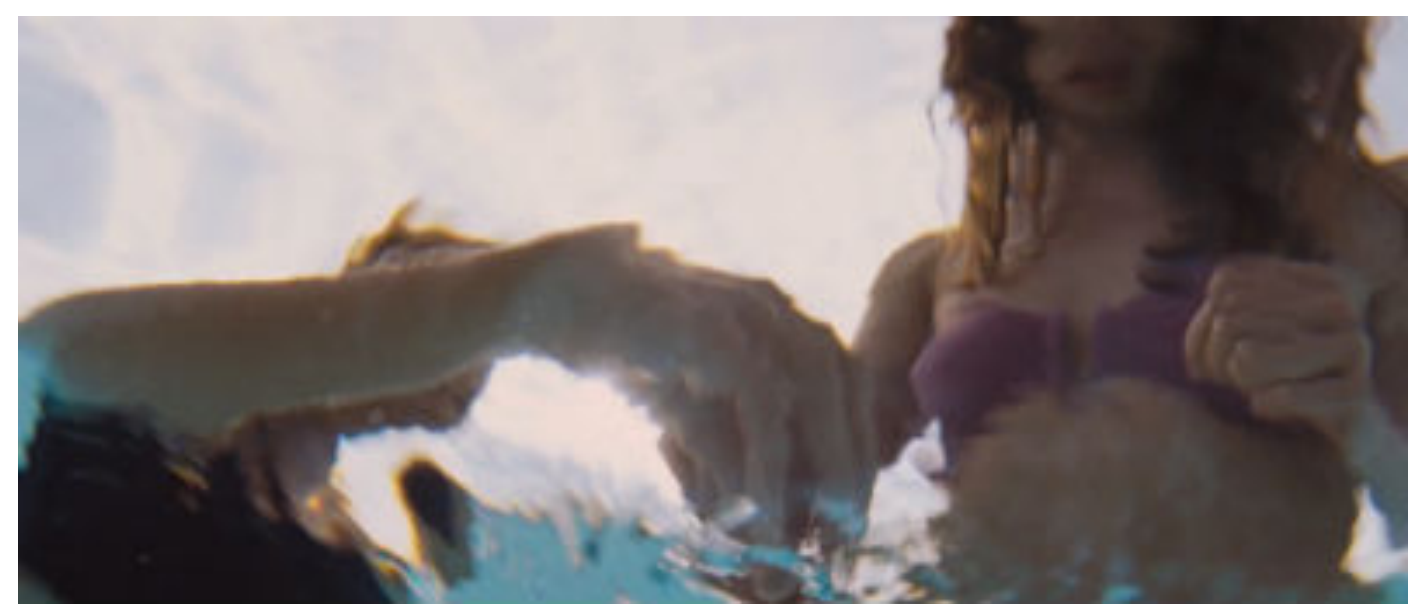

Tatiana e Marina brincam de escrever com os dedos sobre a superfície da água e sob o céu

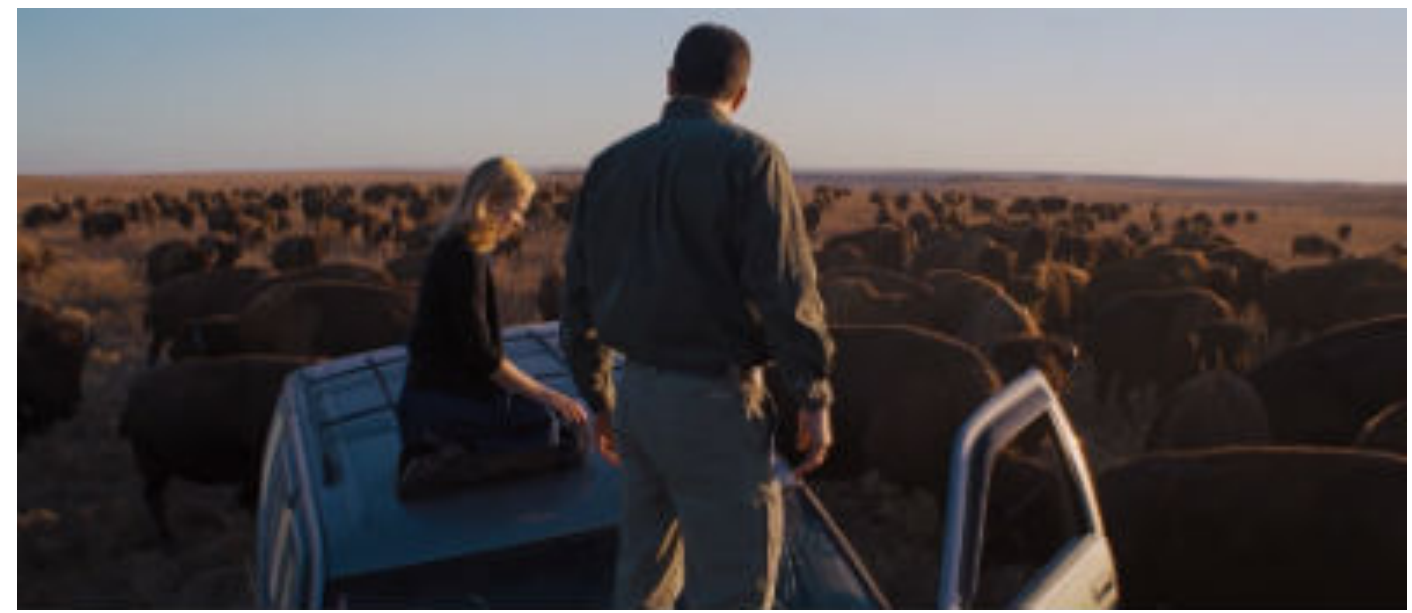

Jane e Neil ilhados em meio ao pasto dos bisões: ao horizonte, mais à terra que ao céu

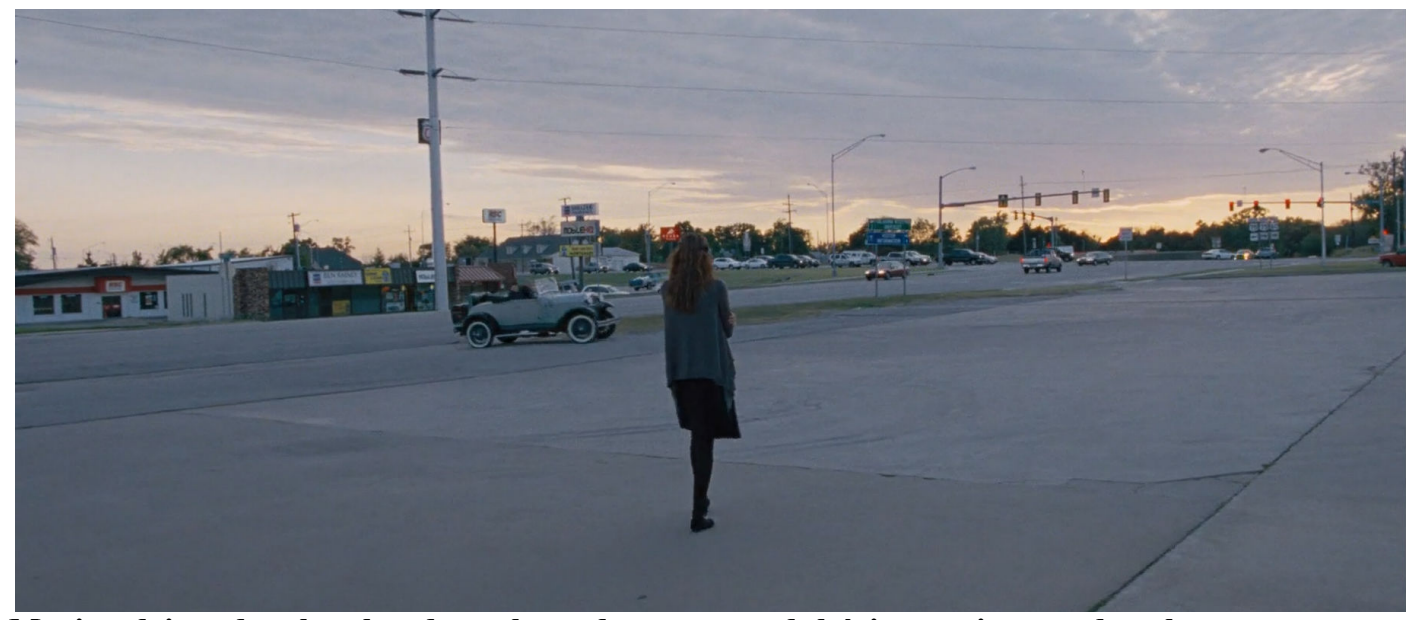

Marina deixando o hotel onde acabara de cometer adultério: sentimento de culpa 


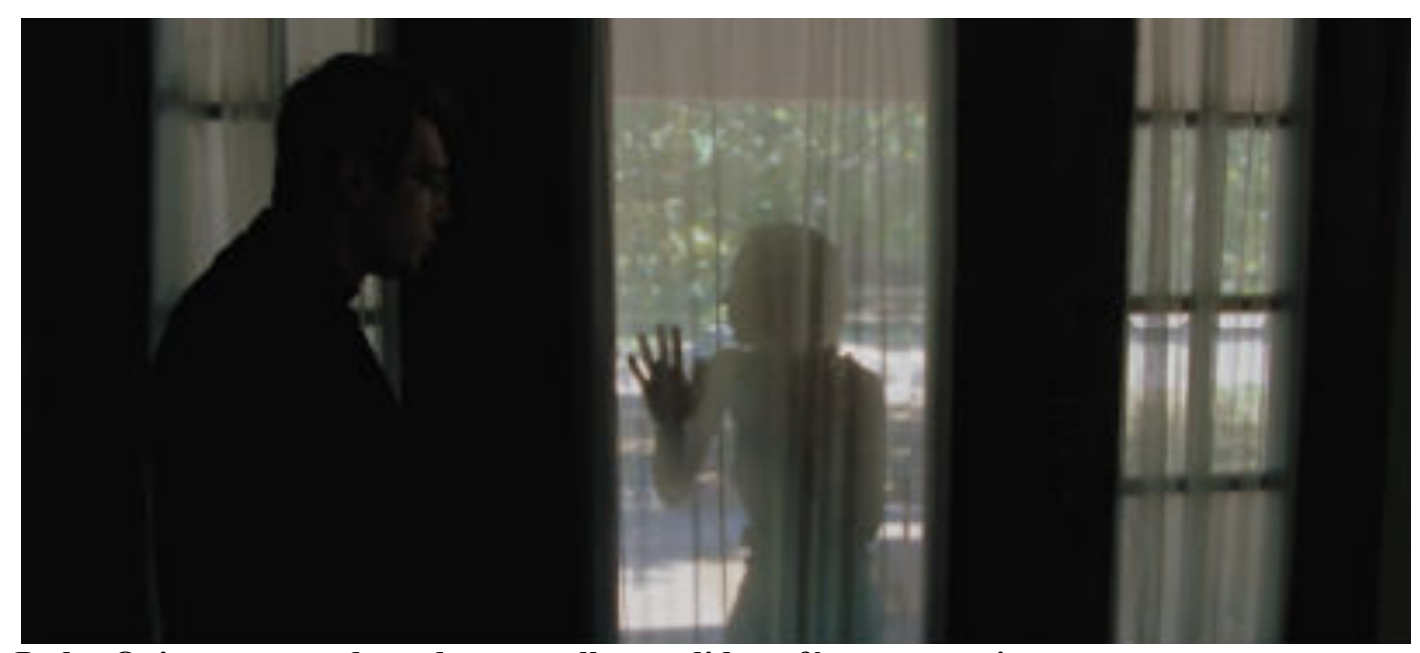

Padre Quintana esconde-se de sua ovelha perdida: a fé que se esvai

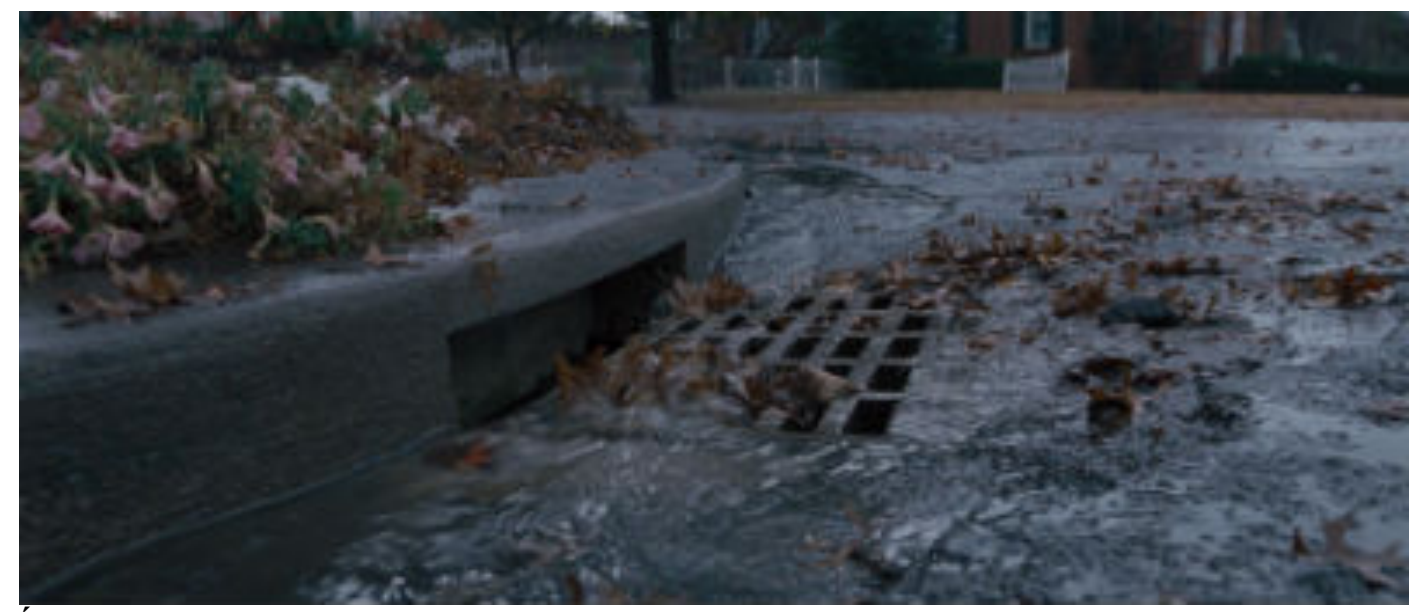

Água escorre com folhas para dentro do esgoto: movimento que descende 